$$
\text { UNIVERSIDADE DE SÃO PAULO }
$$

Faculdade de Filosofia, Ciências e Letras de Ribeirão Preto Departamento de Educação, Informação e Comunicação

Programa de Pós-Graduação em Educação

Galia Xuen Lan Sandoval Jacobo 
Galia Xuen Lan Sandoval Jacobo

\section{NATUREZA ECONÔMICA E POLÍTICA DA REFORMA EDUCATIVA 2013 NO MÉXICO}

Dissertação de Mestrado apresentada ao Programa de Pós-Graduação em Educação da Faculdade de Filosofia, Ciências e Letras de Ribeirão Preto, Universidade de São Paulo, como requisito parcial para obtenção do título de Mestre em Educação.

Área de Concentração: Educação

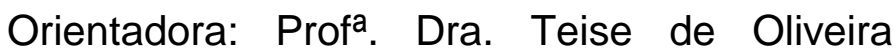
Guaranha Garcia.

Versão corrigida. A versão original eletrônica encontra-se disponível na Biblioteca Central USP Ribeirão Preto e na Biblioteca Digital de Teses e Dissertações da USP (BDTD). 
Autorizo a reprodução e divulgação total ou parcial deste trabalho, por qualquer meio convencional ou eletrônico, para fins de estudo e pesquisa, desde que citada a fonte.

Catalogação da Publicação

Faculdade de Filosofia, Ciências e Letras de Ribeirão Preto 


\section{NATUREZA ECONÔMICA E POLÍTICA DA REFORMA EDUCATIVA 2013 NO MÉXICO}

Dissertação de Mestrado apresentada ao Programa de Pós-graduação em Educação da Faculdade de Filosofia, Ciências e Letras de Ribeirão Preto da Universidade de São Paulo, como requisito parcial para obtenção do título de Mestre em Educação.

Aprovado em:

\section{Banca Examinadora}

Prof. Dr. Instituição:

Julgamento: Assinatura:

Prof. Dr. Instituição:

Julgamento: Assinatura:

Prof. Dr. Instituição:

Julgamento: Assinatura:

Prof. Dr. Instituição:

Julgamento: Assinatura: 
A meus queridos pais, pelo valioso legado que é minha educação, minha formação. Por seus cuidados, apoio, incentivos e por sua grande fé em mim. $A$ vocês, o mais claro exemplo do amor puro e incondicional. 


\section{AGRADECIMENTOS}

Com carinho e agradecimento, a minha família, a meus professores e amigos que em todo momento me tem incentivado e apoiado.

A meus pais Maria Jacobo e Jesús Sandoval, dois grandes e maravilhosos seres humanos, amorosos, solidários, comprometidos e congruentes com o ideal de homem e sociedade que querem legar a seus filhos, netos e ao mundo. Eles são para mim um grande referencial ético, amoroso e de superação profissional. A eles que me incentivam a contribuir positivamente ao mundo com um pequeno grão de areia, a eles com amor dedico este trabalho de pesquisa.

Á Profa. Dra. Teise Garcia, por ter-me brindado a oportunidade de estudar no Brasil, de apreender e incursionar numa área apaixonante que é a educação. Agradeço sua ajuda, seus conhecimentos, compreensão, confiança e paciência ao longo do mestrado. Agradeço-lhe também encarecidamente, os livros emprestados e material bibliográfico compartilhado que têm sido um rico e importante material para meu trabalho.

Aos Professores Doutores Elaine Sampaio Araujo e Germán Sánchez Daza, dos que eu tenho recebido valiosas contribuições e indicações bibliográficas no Exame de Qualificação, dando luz e caminho a meu trabalho.

Aos Professores Doutores Teise Garcia, Elaine Sampaio e Vítor Henrique Paro que despertaram em mim o interesse pela economia política da educação, pelo enfoque marxista na educação.

A meus irmãos Katia e Pável, e a meus sobrinhos Aiumi, Maia e Pável Fernando, os grandes amores e alegrias da minha vida.

A Ondina e Emigdio, queridos amigos do Perú e do México, por ajudar-me e incentivar-me para continuar meus estudos de pós-graduação.

A meus amigos do GREPPE - Grupo de Estudos e Pesquisa em Políticas Educacionais - Ribeirão Preto, Priscilla, Bárbara, Simone, Aline e Eduardo, por seu carinho, ajuda e cumplicidade.

A Sonia, Irene, Nazaré e a Fátima, grandes amigas, mães e conselheiras de vida. Com elas minha vida no Brasil foi uma benção.

A Graça um maravilhoso anjo que chegou no momento justo na minha vida para dar-me luz, ajuda, e para brindar-me uma incrível amizade. 
A Vanessa Espitia por sua sabedoria, por estar sempre perto de mim, por sua bela e entranhável amizade.

A Tauani, uma grande e querida amiga, com quem comparto uma visão do mundo.

A Diana por seu fantástico humor e optimismo, uma amiga de estudo e longas falas.

A Naiara Santos por seu imenso carinho e sólida amizade.

A Lucia uma amiga solidária e amorosa quem sempre teve tempo para mim.

A Ignacio, quem me ajudou na última fase do mestrado com sua especial amizade e seus preciosos conhecimentos de informática.

A os dois grupos de biodança no México e no Brasil, a meus professores Adriana Macias, Helena, Rosa e Werner, a meus companheiros de dança que são uma grande família para mim.

A todos meus amigos e amigas brasileiras, à gente linda que eu conheço e que me brindaram carinho, confiança e me alentaram em todo momento.

Á Organização dos Estados Americanos e ao Grupo Coimbra de Universidades Brasileiras (OEA-GCUB), á Universidade de São Paulo (USP), pela bolsa de estudos recebida para realizar meus estudos de mestrado em Educação no Brasil. 
No sólo de pan vive el hombre. Yo, si tuviera hambre y estuviera desvalido en la calle no pediría un pan; sino que pediría medio pan y un libro. Y yo ataco desde aquí violentamente a los que solamente hablan de reivindicaciones económicas sin nombrar jamás las reivindicaciones culturales que es lo que los pueblos piden a gritos. Bien está que todos los hombres coman, pero que todos los hombres sepan. Que gocen todos los frutos del espíritu humano porque lo contrario es convertirlos en máquinas al servicio de Estado, es convertirlos en esclavos de una terrible organización social. (GARCíA LORCA, 2016). 


\section{RESUMO}

Este trabalho surge da preocupação que tem adquirido a acelerada dinâmica de mercantilização das economias a nível internacional neste século XXI, mediante a aplicação de reformas econômicas, políticas e sociais que favorecem a abertura da economia e das instituições públicas ao setor privado, em detrimento dos direitos sociais e da qualidade de vida da maioria da população mundial. No caso da educação, este processo de descentralização para o mercado é evidenciado por vários autores (BALL, 2008; HILL, 2003; ROBERTSON, VERGER, 2012; PERONI, OLIVEIRA, FERNANDES, 2009; KRAWCZYK, 2005, entre outros), assim como as graves consequências de grande exclusão social, de inequidade, de homogeneização e empobrecimento da educação (ver ROBERTSON; VERGER, 2012), e da submissão internacional a uma ideologia hegemónica: a lógica neoliberal do lucro, da competitividade, da individualidade, da liberdade de seleção, e da supremacia do mercado sobre o social. A administração e organização, das práticas educacionais estão reconfigurando-se sob esses eixos neoliberais. Neste trabalho se estuda esse processo neoliberal na educação, analisando a experiência do México, que nos anos noventa principalmente, inicia com políticas de descentralização educacional e de gestão de qualidade nas escolas, promovidas por grandes organismos internacionais, que levaram à promulgação e implementação de grandes reformas nos decênios seguintes. A última grande mudança constitucional, conhecida como a "Reforma Educativa 2013", é nosso objeto de estudo. Partindo do princípio da totalidade da teoria marxista, pretende-se compreender a articulação do movimento capitalista do século XXI a nível internacional, com as mudanças econômicas da economia mexicana (a reforma laboral) e por sua vez, destas com a educação. Retomando a Marx (1977), parte-se da tese de que as relações sociais de produção condicionam as práticas sociais (à educação), assim como a consciência dos homens. Desde a perspectiva marxista a educação é vista nesta pesquisa, como um processo histórico de produção e apropriação da cultura pelo homem (LEONTIEV, 1978; VIGOTSKI, 2004) que possibilita a formação do homem ciente e revolucionário, que contribui na sua emancipação para a construção de um sistema econômico mais justo (VIGOTSKI, 2015).

Palavras-chave: Homem. Educação. Alienação do trabalho. 


\begin{abstract}
This research emerges from the concern due to the accelerated dynamics of commodification of economies at the international level in the XXI century, that through the implementation of economic, political and social reforms contribute to economic openness and the involvement of public institutions in the private sector, thus promoting the detriment of social rights and life quality of the majority of the world's population. Regarding the educational field, the decentralizing process to open this sector to private capital is evidenced by several authors (BALL, 2008; HILL, 2003; ROBERTSON, VERGER, 2012; PERONI, OLIVEIRA, FERNANDES, 2009; KRAWCZYK, 2005, et al). In the same way, serious consequences are being observed as a result of social exclusion, inequity, homogenization and impoverishment of education (ROBERTSON; VERGER, 2012). The unconditional international subjection to an hegemonic ideology, the neo-liberalism, has imposed the logic of profit, competitiveness, individuality, freedom of choice and supremacy of market over society. The management and organization of educational practices are being modified under neo-liberalism basis. This research analyzes the neoliberal influence in education, based on the experience in Mexico during the 1990s, mainly, period during which it was implemented several decentralization and quality management policies in schools, promoted by large international organizations and which have led to the promulgation and implementation of major reforms in the following decades. The last constitutional amendment, known as the "Reforma Educativa 2013", is the object of the study. Based on the principle of totality of the Marxist theory, the main goal of this research is to understand the link between the XXI century capitalist development at international level, with the economic changes of the Mexican economy (the labor reform) and the implications on educational matters. Karl Marx (1977) stated that the social relations of production determine the social practices (such as education, among others) and conscience of men. This study analyzes education from the Marxist perspective, in which it is seen as an historical process of production and an appropriation of human culture (LEONTIEV, 1978; VIGOTSKI, 2004), this process allows the education of a conscious and revolutionary human being that could contribute to his emancipation towards the construction of a more equitable system (VIGOTSKI, 2015).
\end{abstract}

Keywords: Human being. Education. Work alienation. 


\section{RESUMEN}

Este trabajo surge de la preocupación que ha adquirido la acelerada dinámica de mercantilización de las economías a nivel internacional en este siglo XXI, con la aplicación de reformas económicas, políticas y sociales, que favorecen la apertura de la economía y de las instituciones públicas al sector privado, en detrimento de los derechos sociales y de la calidad de vida de la mayoría de la población mundial. En el caso de la educación, este proceso de descentralización para el mercado es evidenciado por varios autores (BALL, 2008; HILL, 2003; ROBERTSON, VERGER, 2012; PERONI, OLIVEIRA, FERNANDES, 2009; KRAWCZYK, 2005, entre otros), así como las graves consecuencias de gran exclusión social, de inequidad, de homogeneización y empobrecimiento de la educación (ver ROBERTSON; VERGER, 2012), y del sometimiento internacional a una ideología hegemónica: la lógica neoliberal del lucro, de la competitividad, de la individualidad, de la libertad de selección y de la supremacía del mercado sobre lo social. La administración y organización de las prácticas educativas están reconfigurándose sobre esos ejes neoliberales. Este trabajo estudia ese proceso neoliberal en la educación, a partir de la experiencia de México, que en los años noventa principalmente, pone en marcha políticas de descentralización educativa y de gestión de calidad en las escuelas, promovidas por grandes organismos internacionales y que han llevado a la promulgación e implementación de grandes reformas en los siguientes decenios. La última modificación constitucional, conocida como la "Reforma Educativa 2013", es nuestro objeto de estudio. Partiendo del principio de totalidad de la teoría marxista, se pretende comprender la articulación del movimiento capitalista del siglo XXI a nivel internacional, con los cambios económicos de la economía mexicana (la reforma laboral) y a su vez, de éstos con la educación. Retomando a Marx (1977), se parte de la tesis de que las relaciones sociales de producción determinan las prácticas sociales (entre ellas a la educación), así como la consciencia de los hombres. Desde la perspectiva marxista, la educación es vista en esta investigación como un proceso histórico de producción y apropiación de la cultura por el hombre (LEONTIEV, 1978; VIGOTSKI, 2004), que posibilita la formación del hombre consciente y revolucionario, que contribuye a su emancipación para la construcción de un sistema más justo (VIGOTSKI, 2015).

Palabras clave: Hombre. Educación. Alienación del trabajo. 


\section{LISTA DE FIGURAS}

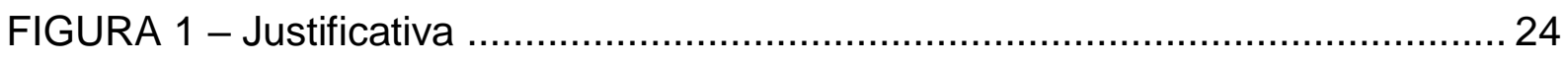

FIGURA 2 - Teoria e metodologia da pesquisa ................................................28

FIGURA 3 - Contexto internacional da reforma educativa 2013 ........................... 32

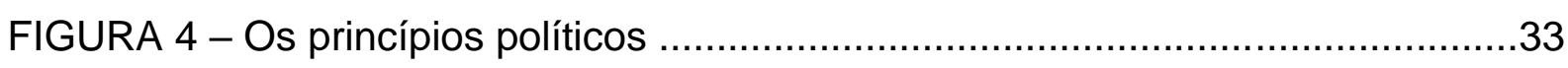

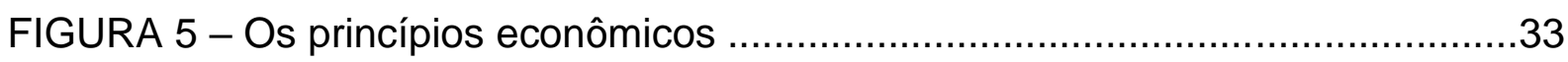

FIGURA 6 - Princípios da qualidade total gerencial ............................................53 


\section{LISTA DE QUADROS}

QUADRO 1 - O sistema educacional mexicano 82

QUADRO 2 - Concorrência pública de provimento e progressão para o magistério público .87

QUADRO 3 - Configuração da reforma constitucional 2013, artigo $3^{\circ}$ .96 


\section{LISTA DE SIGLAS}

ACE - Aliança pela Qualidade da Educação

ANMEB - Acordo Nacional para a Modernização da Educação Básica

APPO - Assembleia Popular dos Povos de Oaxaca

BIRD - Banco Internacional para Reconstrução e Desenvolvimento

C\&T - Ciência e Tecnologia

CNTE - Coordenadora Nacional de Trabalhadores da Educação

ENLACE - Avaliação Nacional do Êxito Acadêmico em Centros Escolares

ETN - Empresas Transnacionais

EXCALE - Exame de Qualidade e Êxito Educacional

FMI - Fundo Monetário Internacional

GREPPE - Grupo de Estudos e Pesquisa em Políticas Educacionais

I\&D - Investigação e Desenvolvimento

IED - Investimento Estrangeiro Direto

INEE - Instituto Nacional para a Avaliação Nacional

IPN - Instituto Politécnico Nacional

LGE - Lei Geral de Educação

MERCOSUL - Mercado Comum do Sul

OMC - Organização Mundial do Comércio

NGP - Nova Gestão Pública

OCDE - Organização para a Cooperação e o Desenvolvimento Económico

PAE - Programas de Ajuste Estrutural

PAN - Partido Ação Nacional

PEC - Programa Escolas de Qualidade

PISA - Programa Internacional de Avaliação de Alunos

PRD - Partido da Revolução Democrática

PRI - Partido Revolucionário Institucional

PRONAE - Programa Nacional de Educação

RIEB - Reforma Integral para a Educação Básica

SEM - Sistema Educacional Mexicano

SEP - Secretaria de Educação Pública

SNTE- Sindicato Nacional dos Trabalhadores da Educação

SPD - Serviço Profissional Docente 
TLCAN - Tratado de Livre Comércio com América do Norte

TT - Transferência Tecnológica

UE - União Europeia

UNESCO - Organização das Nações Unidas para a Educação, Ciência e Cultura UNICAMP - Universidade Estadual de Campinas

UNESP - Universidade Estadual Paulista

USP - Universidade de São Paulo 


\section{SUMÁRIO}

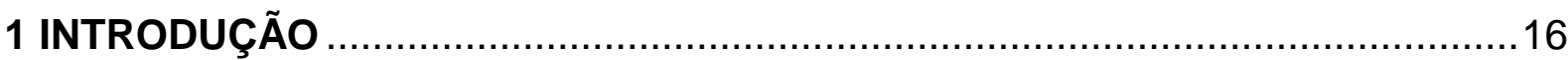

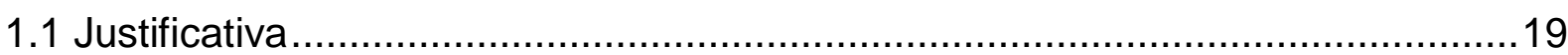

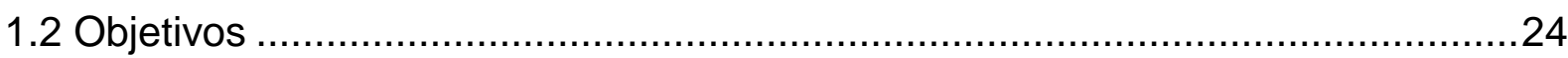

1.3 Metodologia e procedimentos metodológicos .........................................25

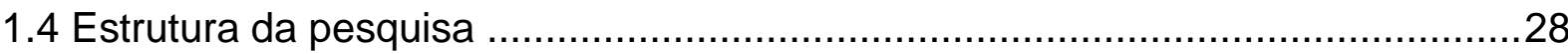

\section{CONTEXTO ECONÔMICO E POLÍTICO. O CAPITALISMO DO SÉCULO XXI E A} EDUCAÇÃO

2.1 A educação no marco da mundialização do capital e do neoliberalismo no século $\mathrm{XXI}$.

2.2 O Tratado de Livre Comercio de América do Norte e a educação no México.....56

2.3 A educação em uma perspectiva histórico-dialética

3 NATUREZA ECONÔMICA E POLÍTICA DA REFORMA EDUCATIVA 2013 NO

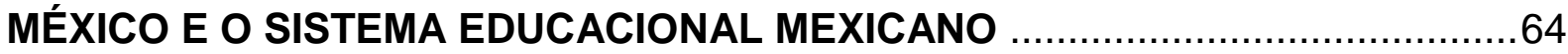

3.1 Breve histórico do Sistema Educacional Mexicano ............................................64

3.2 Estrutura atual do Sistema Educacional Mexicano e a Lei Geral de Educação 2013

3.3 Análise das principais mudanças legislativas da Reforma Educativa 2013 no México

3.4. Os princípios teóricos, econômicos e políticos contidos na reforma educativa 2013 no México

\section{ESTADO NEOLIBERAL FRENTE À RESISTÊNCIA DA SOCIEDADE CIVIL}

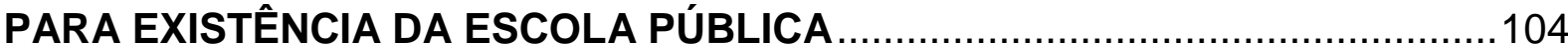

4.1 Breve resenha dos movimentos sociais e da educação no México 104

4.2 A reforma educativa 2013 no México e a resistência política dos professores da educação básica e da sociedade civil. 


\section{INTRODUÇÃO}

A reforma educativa 2013 no México ${ }^{1}$, atinge o ensino básico ${ }^{2}$ e médio superior $^{3}$, e compreende uma série de mudanças que acabam por modificar $\mathrm{o}$ artigo $3^{\circ}$ constitucional e a Lei Geral de Educação, principais instrumentos jurídicos do Sistema Educacional do México. Ela é parte de um processo econômico e político que se inicia, principalmente, com o Acordo Nacional para a Modernização da Educação Básica (ANMEB) em 1992 e com a promulgação em 1993 da Lei Geral de Educação, com o objetivo de descentralizar a educação e de "modernizar" ao sistema educacional (ABOITES, Hugo, 2013; COLL, 2013; ORGANIZAÇÃO PARA A COOPERAÇÃO E DESENVOLVIMENTO ECONÔMICO, 2009).

As reformas promulgadas desde 1992, até a reforma educacional 2013, têm sido impulsionadas e aplicadas coercivamente (ROSARIO, 2010) pelos organismos financeiros internacionais tais como o Banco Mundial, o Fundo Monetário Internacional (FMI), a Organização para a Cooperação e o Desenvolvimento Econômico (OCDE), e a Organização das Nações Unidas para a Educação, Ciência e Cultura (UNESCO).

O grande objetivo procurado de todas estas reformas educacionais tem sido o crescimento econômico dos países em desenvolvimento via a universalização do ensino fundamental, a eficácia do ensino e a qualidade da educação, segundo os interesses desses mesmos organismos internacionais. Estes aspectos estão presentes nas reformas no México ao longo destes 21 anos.

\footnotetext{
${ }^{1}$ Os Estados Unidos Mexicanos (nome oficial do país), é uma república federal com 31 estados e um Distrito Federal. Este é um país em que existem diferentes expressões culturais, com 62 povos indígenas, cada um com sua própria linguagem (68 línguas com 364 variantes) e costumes (COMISIÓN NACIONAL PARA EL DESARROLLO DE LOS PUEBLOS INDÍGENAS, 2006; MONTEMAYOR, 2010). Uma verdadeira reforma educativa no México precisa ter em conta o fato de que de um total de 119 milhões 530 mil 753 mexicanos (censo de população para o ano de 2015), o 21.5\% seja indígena, que - 6.5\% da população fala só uma língua indígena e, que o $5.5 \%$ da população total é analfabeta principalmente nas comunidades indígenas - (COMISIÓN NACIONAL PARA EL DESARROLLO DE LOS PUEBLOS INDÍGENAS, 2006; INSTITUTO NACIONAL DE ESTADÍSTICA Y GEOGRAFÍA, 2017a; 2017b); de que existem grandes diferenças educacionais nos estados da república, entre outras questões, e que fazem impossível pensar em uma reforma educacional homogênea. Como veremos no capítulo 3, é preciso um conhecimento da realidade educacional para desenhar uma verdadeira política educacional em favor de um interesse social. (SAVIANI, 2000).

${ }^{2}$ Que compreende a educação infantil, com uma duração de três anos; o ensino fundamental, de seis anos letivos e o ensino secundário, de três anos. Ver subitem 3.2.

$3 \mathrm{O}$ ensino médio superior corresponde ao bacharelado no Brasil, ministrado aos adolescentes com idades que vão dos 15 aos 18 anos, aproximadamente; este é um estágio anterior ao ensino superior. Ele tem uma duração de três anos e é atualmente obrigatório para todos os mexicanos.
} 
As principais propostas da reforma educativa 2013 são:

a) a regulamentação do Instituto Nacional para a Avaliação da Educação, com o objetivo de garantir a eficiência na educação obrigatória: básica e média superior;

b) a institucionalização do Serviço Profissional Docente, com o objetivo de regular o ingresso, promoção e permanência laboral dos professores da educação básica, para a qualidade do ensino;

c) a criação do Sistema de Informação e Gestão Educativa, para regular, coordenar e operar um padrão do sistema nacional educacional;

d) a legalização da autonomia de gestão das escolas de educação básica, com o objetivo de lhes outorgar liberdade de decisão para administrar e buscar seus recursos financeiros e materiais.

Desde seus inícios foi uma reforma amplamente questionada pelos professores da educação básica e da sociedade civil por ela carecer de legitimidade social e por ser só uma reforma laboral e administrativa. Segundo Aboites Hugo (2013), Coll (2013), a Coordenadora Nacional de trabalhadores da Educação (2013) e Hernández (2013), a finalidade desta reforma educativa consiste na avaliação do sistema educacional; entendendo a avaliação, como o instrumento principal do Estado para poder controlar a educação nacional e subordiná-la à lei do mercado.

Esta reforma reflete num nível microeconômico, no nível das instituições sociais, o que acontece econômica e politicamente num nível macroeconômico no sistema capitalista. Se reproduzem as inequidades econômicas e sociais, a administração escolar autoritária, a exploração do trabalho dos professores e trabalhadores da educação, a formação docente alienante; a educação que procura a competitividade, que classifica e que pune; planos de estudo tecnificados que fragmentam a educação; encontram-se nesta reforma, todas as noções econômicas de produção na educação.

Observasse como todas as relações sociais capitalistas se introduzem na educação e, consequentemente, na consciência dos estudantes e professores.

Este trabalho tem como objetivo, analisar as principais leis da reforma educativa 2013, assim como seu contexto econômico e político a nível internacional, para entender o como os princípios do modo de produção capitalista, estão 
relacionados com a atual política educativa no México, legitimando uma determinada prática educativa e social, e organizando um projeto de nação.

Por tanto, analisar os princípios econômicos e políticos do atual modo de produção, nos ajudará a compreender qual perspectiva orienta a educação no México, e quais os valores que estão sendo apropriados na formação educativa e social do homem.

Intentaremos, desenvolver este trabalho com a ajuda da teoria marxista, (LEONTIEV, 1978, 1984; MARX, 1975, 1988; VIGOTSKI, 2015), a partir de uma análise histórica e dialética, sobre a natureza humana, onde a educação cumpre a função de formar ao homem integral, ciente e revolucionário.

Congruente com este objetivo, o presente trabalho de investigação forma parte do Grupo de Estudos e Pesquisa em Políticas Educacionais (GREPPE), que é um grupo acadêmico interinstitucional conformado por pesquisadores e estudantes de graduação e pós-graduação, de três universidades públicas de São Paulo: Universidade de São Paulo, Ribeirão Preto (USP-RP), Universidade Estadual de Campinas (UNICAMP), e a Universidade Estadual Paulista, Rio Claro (UNESP-Rio Claro). O GREPPE caracteriza-se por promover coletivamente o conhecimento teórico e empírico, para a discussão de temas sobre as políticas públicas educacionais no Brasil (RODRIGUES, 2016); nele se valoriza, a experiência educacional internacional que possibilita uma maior compreensão da situação educacional do Brasil, e que permite a formulação de sólidas propostas diante o processo mundial de privatização.

Perante os graves acontecimentos econômicos e políticos vivenciados atualmente no Brasil, é necessário dar uma olhada na dinâmica global capitalista e nas experiências de outros países da região, para entender a inter-relação desses eventos econômico-políticos com o educativo. A lógica neoliberal do lucro, da individualidade, da liberdade de seleção, da supremacia do mercado sob o social, da competitividade, domina internacionalmente as políticas dos Estados nacionais no século XXI, plasmando-se coercitiva e legalmente em todas as áreas sociais, antes restritas ao público e consideradas como direito social. A educação, como direito social está inclusa neste processo de mudança do público para o privado.

A presente pesquisa intentará contribuir com o propósito de este grupo que é "[...] estabelecer discussões sobre políticas públicas educacionais vinculadas ao compromisso com o direito à educação pública, gratuita e de qualidade para todos [...]." (RODRIGUES, 2016, p. 15). 


\subsection{Justificativa}

Segundo a teoria marxista, as relações sociais de produção determinam as diferentes práticas e representações sociais; os indivíduos se apropriam desses significados sociais mediante a atividade prática e a educação. O homem internaliza não a realidade ou as coisas em si mesmas, mas sua significação, a significação que elas têm para a sociedade em seu conjunto, mediante a educação. Desde essa concepção, a educação como prática social, cumpre uma função humanizadora, um papel essencial na formação da personalidade e consciência do homem como ser integral. (MARX, 1977; VIGOTSKI, 1995).

Ao falar de prática social, é preciso pensar na formação da cultura e da sociedade, e assim entender a importância que têm os conceitos de homem e de educação neste trabalho.

A cultura e a sociedade são objetivações materiais e subjetivações ideológicas que o homem como sujeito ativo e social tem vindo a construir de forma coletiva e histórica em sua ânsia de satisfazer as suas necessidades materiais e espirituais. Segundo Ortega y Gasset (1963), o homem não se tem contentado só com o viver ou sobreviver, mas em viver bem e com esse objetivo, ele tem sido capaz de criar tanto "o objetivamente necessário", como "o supérfluo" para cobrir suas "necessidades humanas", necessidades que têm sido construídas historicamente.

O homem como parte da natureza, se diferencia dela precisamente por ser um sujeito com vontade, dono do seu destino, um ser reflexivo, um ser ético que cria valores: "('Isto é bom, isto não é')" (PARO, 2010, p. 24), valores que guiam seus objetivos e sua ação (Ibid.). Essas caraterísticas lhe possibilitaram revelar parte das leis que regem a natureza, conhecimentos e técnicas que lhe tem permitido fazer um uso consciente das suas próprias forças naturais frente a natureza mesma, para transformá-la e apropriar-se dela, deixando sua marca no tempo, na história.

Nesse criar intencionalmente necessidades para ir além do simplesmente viver, o homem com seu trabalho e ciência tem-se constituído, e ao materializar suas ambições e objetivações tem produzido cultura; que podemos definir grosso modo como as produções sociais que o genro humano tem criado em seu atuar social e com a natureza, como por exemplo: a linguagem, a ciência, a técnica, a arte, a filosofia, os valores, as crenças, as instituições sociais, as práticas sociais, etc. Desta forma, o 
homem na produção desses significados sociais e atuando sobre a natureza criou a cultura humana e a história da sua humanização (LEONTIEV, 1978).

Segundo a teoria marxista (LEONTIEV, 1978; MARX, 1988, VIGOTSKI, 1995a; 1995b) quando o homem modifica a natureza externa mediante o trabalho - que é uma atividade prática dirigida por objetivos (MARX, 1988) - ele transforma ao mesmo tempo sua própria natureza interna, desenvolvendo as funções psicológicas superiores (VIGOTSKI, 1995a; 1995b) dando nascimento ao ser social, cultural e histórico, isto é, ao ser humano. É aqui uma importante contribuição do marxismo: a essência ontológica do trabalho.

O trabalho desde a perspectiva marxista, é e tem sido a mediação para a humanização, e também representa a única possibilidade de que o homem se realize de maneira integral, mediante a apropriação cultural. Em contrapartida, no capitalismo, o trabalho é visto como um fim para a consecução de mais-valia, para a exploração, como "[...] fim em si mesmo [...]" (DIAS, 2007, p.35). É aqui uma importante diferença no conceito de trabalho e educação. Temos aqui dois caminhos opostos, o primeiro, que é o marxista, que propõe o trabalho educacional para a constituição do sujeito "[...] detentor de vontade, como autor." (PARO, 2010, p.25); e o segundo, que é a lógica capitalista, que vê na educação um potencial para formar homens, mercadorias produtoras de mais-valia, úteis no trabalho produtivo: uma educação para o trabalho.

O homem visto como sujeito tem conseguido transcender a natureza e fazer história. Com as caraterísticas de homem histórico e de sujeito, ele representa o principal e único objetivo da educação. Uma educação que terá a função de formá-lo na sua integralidade, no significado da apropriação plena da cultura, para sua humanização, para o desenvolvimento da sua consciência e personalidade, sua integração e contribuição à sociedade (PARO, 2010; VIGOTSKI, 1995).

A educação em geral é um processo social, uma prática social, no sentido que a apropriação cultural individual se dá no contato com os homens e com o meio social, seja na família e no círculo social próximo ou na escola.

Segundo a teoria marxista, quando se fala do "social", não se refere exclusivamente a tudo aquilo produzido socialmente pelos homens, mas também às relações existentes e necessárias entre eles para produzir sua existência material. Isto é, o trabalho humano não se realiza de maneira individual. Para sua sobrevivência no 
meio natural, assim como para a produção das suas necessidades se precisa do trabalho conjunto de outros homens.

Nessa atividade criativa e produtiva guiada por um objetivo, processo todo que é o trabalho em se mesmo (MARX apud PARO, 2014; LEONTIEV, 1978), os homens se relacionam, se organizam e estabelecem uma divisão social do trabalho a partir das relações sociais de produção presentes, determinando a organização da sociedade, isto é, o "[...] modo de produção social historicamente determinado [...]" (MARX 1988, p.93).

O trabalho que é um processo de diversas atividades conscientes do homem, é dividido e realizado socialmente; e o resultado desse processo de trabalho coletivo que é a cultura, será um produto social histórico, carregado das crenças, ideias, valores, nível de desenvolvimento científico e tecnológico dessa sociedade, etc.

Desta maneira, o social é condição para a produção e apropriação cultural, necessária para a seguinte produção cultural. E as práticas sociais, produto das relações sociais de produção, organizaram a sociedade desde essas "[...] determinações [sociais] historicamente situadas." (PARO, 2014, p. 24).

Homem, educação, cultura e sociedade são uma unidade, formam parte de um mesmo origem, do trabalho humano que é social, criativo e consciente.

A importância desta relação está no fato de que a formação ética do homem, a natureza social desse homem, a educação, depende em grande parte, das relações sociais, das produções materiais e subjetivas e dos valores que sustentam um determinado modo de produção, em que os interesses econômicos e políticos estão evidentemente presentes.

Vigotski (2000), nos fala o como desde crianças, tomamos consciência da nossa posição social na família e no conjunto da sociedade. As relações sociais que dominam o modo de produção são incorporadas na consciência e na personalidade do novo homem. Este fato assume grande importância, se pensamos na estrutura econômica existente, na sociedade que queremos e por tanto nos valores, na cultura e o mundo que se lega às novas gerações, e em cujas mãos estará a sua vez o futuro da natureza e da sociedade.

No atual modo de produção capitalista, a sociedade se organiza a partir da propriedade privada dos meios de produção. Os meios de produção são a soma dos objetos de trabalho e os meios de trabalho, isto é, são "[...] todos os elementos 
materiais que, direta ou indiretamente, participam do processo de produção." (MARX apud PARO, 2014, p.28) de bens e serviços.

Nesta sociedade capitalista, uma parte da população -os capitalistas- é dona dos meios de produção. Ela conta com os recursos econômicos e materiais e, portanto, tem o poder para controlar o processo de produção e o funcionamento da sociedade, em quanto a outra parte dos trabalhadores-, possui somente sua força de trabalho para vendê-la aos donos dos meios de produção, e desta forma subsistir. No processo de produção capitalista, dá-se a apropriação do trabalho alheio, do capitalista sobre o produto final do trabalhador.

Nos encontramos diante de uma sociedade administrada "[...] a serviço de uma classe em particular e não do homem em geral." (PARO, 2014, p. 75); de uma sociedade dividida em classes sociais, com objetivos de produção econômicos e não sociais; de uma estrutura econômica que sobrevive graças à exploração do homem sobre o próprio homem, rebaixando ao homem a simples objeto de produção da maisvalia, caraterística principal do capitalismo 4 .

Neste modo de produção, o principal incentivo para produzir mercadorias, é o lucro, "o incremento do capital"5" (MARX, 1988, p.185).

No capitalismo, o trabalho deixa de ser constitutivo do ser humano, se organiza de tal forma, que destitui ao homem de sua humanidade, se fragmenta seu ser e suas aspirações, aliena-se de sua essência, converte-se numa mercadoria e ferramenta mais do processo de produção.

Para a produção, reprodução e ampliação do capital, força motora da sociedade capitalista, é preciso incrementar a produtividade da força de trabalho, que significaria o aumento da produção em uma mesma jornada de trabalho. Tornando mais eficaz o processo de produção, reorganizando a produção e aumentando a produtividade laboral, o capitalista coloca-se como um grande competidor no mercado de bens e serviços.

Já a finais do século XVIII, Adam Smith (1999) - na sua obra "Uma investigação sobre a natureza e as causas da riqueza das nações ${ }^{6 "}$ (1776) -, desenvolve sua teoria

\footnotetext{
4 "Podemos dizer, com Paul Marlor Sweezy, que 'o que é específico ao capitalismo é, portanto, não o fato da exploração de uma parte da população pela outra' - já que em sociedades não capitalistas, como, por exemplo, a escravista e a feudal, isso também ocorre -, 'mas a forma que essa exploração assume, ou seja, a produção da mais-valia' [...]" (PARO, 2014, p. 47).

5 O capital segundo Marx (1988, p.39) é "[...] a propriedade privada dos produtos do trabalho alheio."

${ }^{6}$ Inquiry into the nature and causes of the wealth of nations, título da sua obra publicada em inglês.
} 
econômica que fala da importância da divisão do trabalho assim como da capacitação da força de trabalho (entre outros temas) para aumentar a eficiência e a produtividade laboral. Esta divisão e especialização do trabalho, possibilita segundo o autor:

a.) uma crescente destreza laboral dos operários;

b.) uma poupança do tempo por deslocamentos na cadeia de produção;

c.) a introdução de invenções de novas maquinas que reduzem o tempo de trabalho por operário.

Só a educação possibilita o desenvolvimento das forças produtivas; faculta a capacitação laboral (forma distorcida e incompleta da educação), que viabiliza o conhecimento parcial e/ou capacidades que se precisam para executar uma atividade específica e segmentária no processo de produção. O desenvolvimento das forças produtivas eleva a produtividade do trabalho, racionaliza o processo de produção, com a possibilidade de que o capitalista incremente sua produtividade e lucro.

Cada vez que o capitalismo adquire formas mais avançadas de exploração e de ampliação do capital, vai apropriando-se não apenas da natureza geográfica e humana, mas das mesmas relações sociais, da produção cultural toda que possa ser convertida em mercadoria e lucro. Com essa finalidade, ele se apropria do aparelho de Estado, para realizar mudanças legislativas necessárias que favoreçam suas atividades empresariais localmente e internacionalmente, para poder ampliar seu capital.

No século XXI somos testemunhas dos recursos ideológicos e mecanismos de poder utilizados pelo Estado, em mãos da classe dominante (os capitalistas) para o funcionamento e expansão do capitalismo. O neoliberalismo, sua fase atual que iniciou nos anos oitenta do século passado, se caracteriza pela implementação de "reformas estruturais" para a liberalização, desregulação e privatização das economias. Como vimos, pela sua importância, a educação coloca-se como parte dessas "reformas" econômicas.

Tendo em vista as questões consideradas até aqui, faz-se necessário, estudar a reforma educativa 2013, para entender de que modo ela legitima uma determinada prática educativa e social.

A figura 1, apresenta os argumentos que justificam a presente pesquisa. 


\section{Figura 1 - Justificativa}

AS RELAÇÕES DE PRODUÇÃO DETERMINAM AS PRÁTICAS E REPRESENTAÇÕES SOCIAIS
OS INDIVIDUOS SE APROPRIAM

DESSES SIGNIFICADOS SOCIAIS MEDIANTE A ATIVIDADE PRÁTICA E A EDUCAÇÃO
A EDUCAÇÃO COMO PRÁTICA SOCIAL, CUMPRE A FUNÇÃO DE CONSTITUIR, DE FORMAR A PERSONALIDADE E A CONSCIÊNCIA DOS HOMENS
ESTUDAR A REFORMA EDUCATIVA 2013,

PARA ENTENDER DE QUE MODO ELA LEGITIMA UMA DETERMINADA PRÁTICA EDUCACIONAL E SOCIAL

Fonte: Elaborado pela autora

\subsection{Objetivos}

Considerando a grande importância da educação na formação da personalidade e consciência do homem, resulta necessário compreender como a educação se relaciona com a estrutura econômica e, portanto, com o modo de produção vigente.

A proposta desta pesquisa é entender como as relações sociais de produção capitalista do século XXI são fatores determinantes nas definições de políticas que organizam o sistema educativo mexicano. Isto é, como os princípios econômicos e políticos do modo de produção capitalista se concretizam numa legislação, com a aparência de uma reforma educativa, para legitimar uma prática educativa neoliberal.

Por tanto, o principal objetivo deste trabalho é: conhecer, analisar e compreender a natureza econômica e política da reforma educativa 2013 no México, para entender qual a relação entre os âmbitos econômicos e políticos com o educativo e qual o papel dado ao educativo nesta fase neoliberal do sistema capitalista.

O materialismo histórico-dialético, a base metodológica desta pesquisa, orientará no caminho a percorrer e com ajuda da teoria definir as categorias de análise que nos permitam chegar à compreensão dos princípios teóricos, econômicos e políticos contidos nessa reforma constitucional educativa 2013.

Os seguintes objetivos específicos, definiram as ações para alcançar o objetivo geral e para organizar os capítulos do presente trabalho: 
a) compreender os princípios teóricos, econômicos e políticos contidos na reforma educativa 2013;

b) conhecer e analisar as principais mudanças legislativas dessa reforma educacional;

c) entender como os princípios do modo de produção capitalista estão presentes na reforma educativa 2013 e como esses princípios a determinam;

d) apresentar um breve histórico da luta contra hegemônica dos professores do ensino básico no México, como as possibilidades para a construção de uma educação pública, gratuita, humana e integral.

\subsection{Metodologia e procedimentos metodológicos}

Toda pesquisa social ${ }^{7}$ é um processo de construção do conhecimento, conhecimento que nos permite enxergar e conhecer a realidade, seu movimento, suas relações e suas leis, e desde essa compreensão poder incidir nessa concretude material e social, no objeto de estudo (KOPNIN, 1978; MINAYO, 2008; OLIVEIRA, 2014; SHUARE, 1990). Toda investigação que forme parte das ciências sociais parte de um posicionamento sobre a realidade social, a teoria e metodologia escolhidas refletiram a concepção do mundo que se tem para desde aí traçar o caminho a seguir na consecução dos objetivos de pesquisa. É de suma importância a escolha destas ferramentas de trabalho para captar a essência do fenômeno em questão, com a maior objetividade possível, tendo bem em conta aquilo que Gadotti (1988), Kopnin (1978), Minayo (2008) e Oliveira (2014) destacam respeito à neutralidade da ciência. Si todo conhecimento surge da observação e reflexão da atividade prática humana, que the permite captar as leis naturais e sociais para objetiva-las no desenvolvimento da produção material, intelectual e espiritual: isto é as leis do ser, desse social, apropriadas pelas leis do pensamento que permitem a construção teórica e metodológica da realidade, temos em movimento um processo dialético de subjetivação e objetivação, não pudendo existir total independência a uma visão

\footnotetext{
7 Uma definição de pesquisa social nos é dada por Minayo (2008, p.47): "Compreendo por Pesquisa Social os vários tipos de investigação que tratam do ser humano em sociedade, de suas relações e instituições, de sua história e de sua produção simbólica."
} 
política do mundo. Em palavras de Lênin citado por Kopnin (1978, p. 52): "As leis da lógica são reflexos do objetivo no subjetivo da consciência do homem".

$\mathrm{Na}$ presente pesquisa, escolhemos uma teoria e metodologia que nos permitisse entender o fenômeno social como parte de um todo, de um universo social produto do trabalho humano, que produz sob uma determinada organização social econômica, política e jurídica, inserido, portanto num determinado modo de produção com leis econômicas próprias. Se as leis do pensamento são um reflexo das leis do ser, o processo de conhecimento do objeto de estudo tem que desenvolver-se e surgir nesse contexto histórico-social. Para entender o fenômeno de estudo, tentamos nos referenciarmos na teoria e metodologia escolhidas e desde aí poder entender a essência do objeto de estudo com a maior objetividade, dentro de nossa linha teórica.

Tomando em conta o objetivo geral desta pesquisa, que é a caracterização e análise econômica e política da reforma educativa 2013 no México, assumimos como pressuposto teórico do trabalho: que os princípios econômicos e políticos do modo de produção capitalista se objetivam numa prática educativa capitalista, e portanto num projeto de sociedade. O econômico determina a superestrutura, e esse social a consciência do homem que está mediada pela educação.

Para os fins desta pesquisa de tipo qualitativa documental, adotamos como marco teórico o marxismo e como marco metodológico o materialismo históricodialético; e como base material, fontes primárias em documentos públicos oficiais, teórica e legislativa.

A pesquisa qualitativa abrange uma série de técnicas e teorias que definem 0 caminho para o conhecimento da realidade. Ela aborda questões sócio-históricas, em que se privilegia a construção do concreto-objetivo, a partir da análise e entendimento da subjetividade do ser, das relações e dos significados sociais do fenômeno em questão (MINAYO, 2008). Em palavras de Minayo (Ibid., p. 57): "Caracteriza-se pela empiria e pela sistematização progressiva de conhecimento até a compreensão da lógica interna do grupo ou do processo em estudo."

Porém é preciso ter em conta que qualidade e quantidade são parte de um mesmo processo dialético, e para os fins desta pesquisa nos focamos sobretudo no entendimento do subjetivo-qualitativo para a compreensão da realidade. Desta mesma forma, teoria e metodologia são dos instrumentos que juntos nos permitiram chegar ao resultado, ao conhecimento de nosso objeto de estudo. 
A base teórica deste trabalho se sustenta no marxismo, tomando como principais categorias de análise: o homem, a educação e a alienação do trabalho.

As etapas da pesquisa são: 1.) delimitação do objeto de estudo, 2.) contexto do fenômeno, 3.) conhecimento do objeto de estudo, 4.) reflexão, interpretação e integração das etapas da pesquisa.

Esta pesquisa parte de uma análise do universal: do contexto econômico e político capitalista, a nível internacional, para compreender o funcionamento do sistema educativo mexicano, e propriamente a relação que a reforma educativa 2013 (o singular) mantêm como esse universal. A categoria trabalho como a mediação (OLIVEIRA, 2001) entre as relações de produção do sistema capitalista e a forma que esta assume no processo educacional, num país capitalista, o México; revela como a lógica econômica de lucro, a organização produtiva e laboral capitalista está sendo transferida ao sistema educacional desde a administração escolar, aprofundando a alienação do trabalho pedagógico.

Desde a teoria marxista, compreende-se a constituição humana, como um ser com representações sociais, objetivações e significados apropriados na produção de sua vida material, social, política e espiritual. Estas representações sociais como produto das relações sociais caraterísticas de um determinado modo de produção, condicionam a personalidade e consciência dos homens (LEONTIEV, 1984; MARX, 1977; MINAYO, 2008).

A educação desde esta perspectiva é a mediação para a apropriação cultural produzida historicamente em sociedade. Mediante 0 trabalho ou a atividade dos homens, os significados sociais são subjetivados e apropriados. A importância da educação está justamente, na formação da consciência e da personalidade nos homens. Logo, o processo educacional considera-se como elemento transformador da sociedade (LEONTIEV, 1984; VIGOTSKI, 2015).

Compreender o fenômeno educacional, apoiando-nos no materialismo histórico-dialético significa analisar a totalidade, assim como as especificidades histórico sociais (MINAYO, 2008, p. 26).

Portanto, com ajuda de informação documental, jurídica e teórica, este trabalho parte de um breve estudo do cenário econômico e político internacional, para ir ao singular o específico, a reforma educacional 2013 no México. A figura 2, resume as caraterísticas metodológicas deste trabalho e nos mostra o rumo a percorrer para o conhecimento de nosso objeto de estudo: a Reforma educativa 2013. 
Figura 2 - Teoria e metodologia da pesquisa

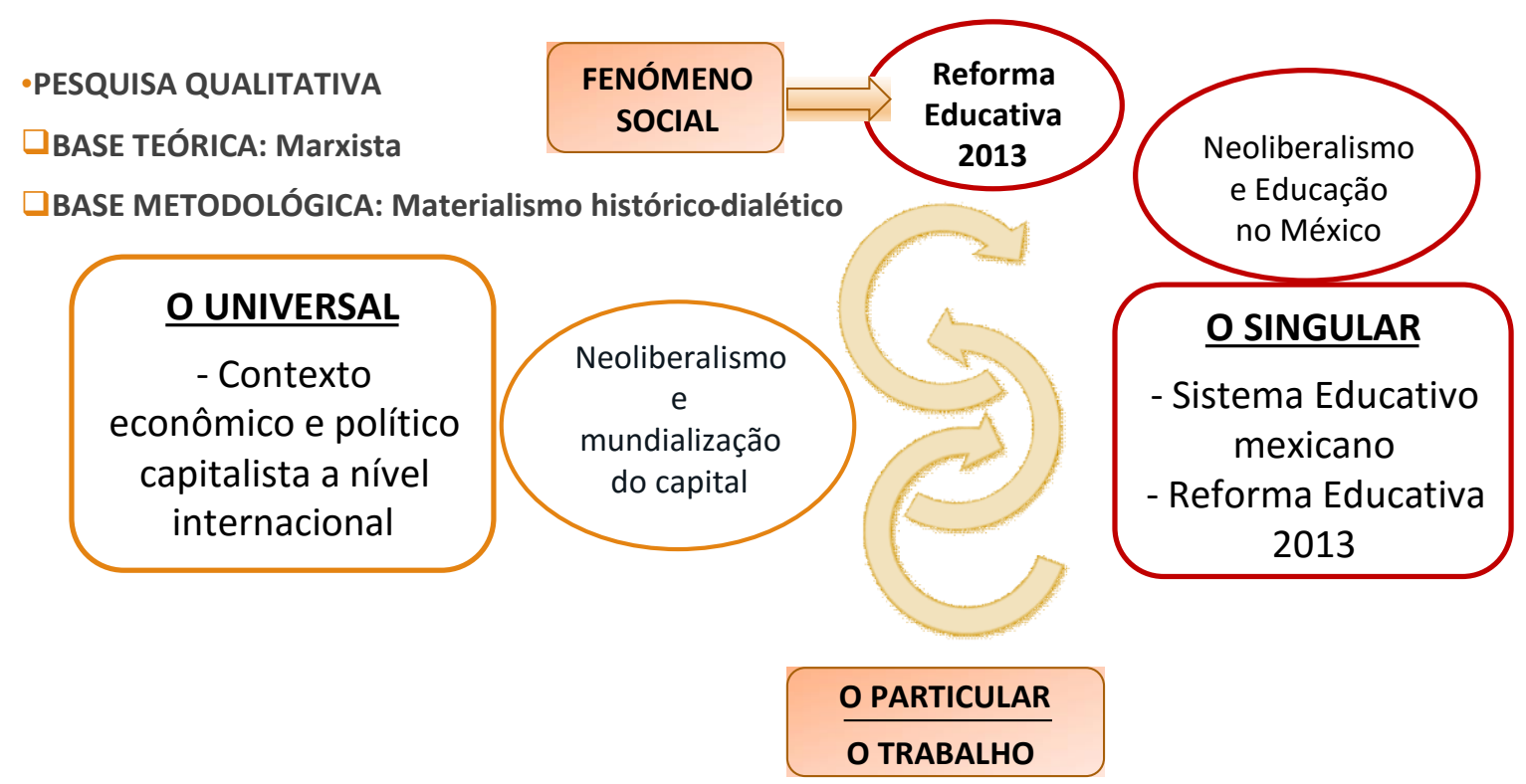

Fonte: Elaborado pela autora

\subsection{Estrutura da pesquisa}

A partir dos objetivos e da metodologia identificados acima, a presente pesquisa organiza-se em quatro capítulos.

No capítulo 2, em base a referências bibliográficas, exporemos o contexto histórico e teórico da reforma educativa 2013 no México. Um primeiro passo, será analisar as principais caraterísticas dos princípios econômico e político do capitalismo no século XXI, identificando no plano econômico, a mundialização do capital: produção, reprodução e ampliação do capital; e no plano político, o neoliberalismo: a liberalização, desregulação e privatização das economias. Para entender que o funcionamento e a lógica capitalista abrangem o total das instituições sociais, em que a educação tem um papel essencial para a manutenção do sistema econômico.

Esta análise teórica nos ajudará a entender as relações sociais e econômicas que se têm desenvolvido no sistema econômico do século XXI e que têm configurado 0 atual sistema educacional.

Tendo a dinâmica internacional do capital, falaremos brevemente das caraterísticas que adoptou a educação no comércio internacional no México. 
Uma terceira parte deste segundo capítulo, será apresentar brevemente a base teórica que servirá de guia para compreender nossas principais categorias de análise: homem, educação e trabalho, desde a teoria histórico cultural.

No capítulo 3, apoiando-nos em documentos legislativos e referências bibliográficas analisaremos a reforma educativa 2013 no México. Mostraremos um breve histórico das reformas educativas no México desde os anos 1990 em que começa a descentralização a educação para o mercado. Posteriormente, analisaremos as principais modificações legislativas à educação em 2013 e as diferenças e semelhanças que existem entre as atuais mudanças educacionais e as anteriores.

Intentara-se entender o como os princípios econômicos e políticos advindos das relações de produção capitalistas encontram-se presentes na reforma educativa 2013, legalizando uma prática educativa capitalista.

No capítulo 4. Em base a referências bibliográficas, faremos uma resenha do movimento do magistério no México em 2013, que é a resposta dos professores e da sociedade em geral diante do movimento hegemônico na educação. 


\section{CONTEXTO ECONÔMICO E POLÍTICO. O CAPITALISMO DO SÉCULO XXI E A EDUCAÇÃO}

Para compreender a essência da reforma educativa 2013 e o papel que ela tem nas mudanças econômicas e políticas atuais no México, é preciso examinar as relações sociais de produção capitalista que organizam o trabalho e que determinam a existência de um determinado tipo de educação.

Neste capítulo, analisaremos as transformações econômicas e políticas a nível internacional no século XXI para compreender o contexto em que surge a reforma educativa 2013. Num primeiro momento, examinaremos os princípios políticos, que é o neoliberalismo, ademais dos princípios econômicos - a mundialização do capital é que formam parte desta reforma; para posteriormente, entender a função que tem a educação no México dentro do comércio internacional.

Compreenderemos, como as relações de produção capitalistas estão sendo reproduzidas no âmbito educacional no México, mediante a aplicação de "reformas estruturais" que tem precisado de uma nova participação do Estado na economia. Estas chamadas reformas, têm sido a ponte para a ingerência política dos grandes organismos internacionais na economia toda, privatizando e eliminado todo sentido social das grandes conquistas dos povos, como a educação e a saúde.

Entanto as relações sociais de produção determinam as práticas sociais, para compreender o tema educacional é imprescindível conhecer o sistema econômico em que ele se tem gerado, seu entorno institucional, econômico, ideológico, político e social. Neste trabalho nos centraremos nos aspectos econômicos e políticos. No seguinte subitem, faremos uma breve análise da estrutura econômica capitalista para compreender o papel que tem a educação nessa dinâmica econômica.

\subsection{A educação no marco da mundialização do capital e do neoliberalismo no século XXI.}

Após a crise de acumulação do capitalismo dos anos setenta, a intervenção do Estado na economia e o Estado social são questionados por diversos setores: intelectuais, políticos e homens de negócio, organismos internacionais e grandes corporações, todos eles relacionados à ideologia neoliberal, conforme indicam Anderson (1995), Rosario (2010) e Toussain (2004). 
Os neoliberais edificaram uma grande rede política e econômica a nível internacional para expandir sua ideologia de livre mercado, "[...] apoiada por um vasto e eclético corpo teórico [...]" (TOUSSAIN, 2004, p.181), ação liderada por organismos internacionais como o Banco Mundial e o Fundo Monetário Internacional (FMI), após o Consenso de Washington (1989). (ANDERSON, 1995).

Aproveitando a conjuntura internacional, ao longo das décadas dos oitenta e noventa, estes organismos financeiros (representantes da hegemonia capitalista) aplicaram $^{8}$ de forma homogênea e inflexível, os "Programas de Ajuste Estrutural" (PAE), de corte neoliberal que redefiniram a participação do Estado na economia. Os dois objetivos principais destes programas para fazer frente à crise fiscal internacional, são: a estabilidade macroeconômica e a reestruturação econômica, que tinham como propósito o crescimento econômico, pela via do controle das finanças públicas e da apertura ao comercio internacional. Estas medidas significaram a diminuição do papel do Estado, com políticas de redução no gasto social -como na educação e a saúde-, a privatização das empresas e serviços públicos, a liberalização do comercio e das finanças e a desregulamentação do marco legal para favorecer a entrada do investimento nacional e estrangeiro (ROSARIO, 2010; FLORES, 2010; IBARRA, 2006).

De acordo com Altman (2002) e Peixoto (1995), este discurso de estabilidade e progresso econômico dos organismos internacionais como justificativa dos PAE, procurou em realidade um clima de estabilidade para os investimentos estrangeiros e a acumulação do capital. Para Rosario (2010), estes pacotes econômicos significaram além disso, o incremento da dívida externa para os países latino-americanos, enquanto sua aplicação foi a única via de negociação para obterem empréstimos internacionais. Razão pela qual a autora refere-se a estes programas como de "mecanismos extorsivos" para aplicar a lógica neoliberal (Ibid, p. 239). Uma extorsão e ingerência política disfarçada de liberdade econômica que continua da forma "mais agressiva" no século XXI com a interferência e enfraquecimento das soberanias nacionais, desnacionalização das administrações públicas e reorganização do território geopolítico e econômico mundial (ESTAY, 1993).

8 “[...] as recomendações de caráter neoliberal sugeridas para os países subdesenvolvidos sintetizaramse em 1989 nas reformas propostas pelo chamado Consenso de Washington." (FLORES, 2010, p.49, tradução nossa). 
No caso do México (assim como nos outros países latino-americanos), os PAE, significaram o fim de uma estratégia estruturalista de crescimento e industrialização "desde dentro", para iniciar uma fase neoliberal, sob um Estado não protecionista que foi privatizando paulatina e rapidamente a economia toda. A Reforma educativa 2013, é parte deste processo, em que se legaliza formalmente a privatização da educação, com mudanças legislativas no plano administrativo e laboral.

A figura 3, mostra o contexto internacional em que surge a reforma educativa 2013, nosso tema de pesquisa.

\section{Figura 3 - Contexto internacional da reforma educativa 2013}

\footnotetext{
$\square$ Contexto econômico e político do século XXI:

1) No plano econômico: Mundialização do capital: Produção, reprodução e ampliação do capital.

2) No plano político: Neoliberalismo: Liberalização, desregulação e privatização das economias.
}

$\square$ Crise internacional de 1973 e a transição econômica e política nos anos 1980

Suporte ideológico da

mundialização do capital

Modelos de desenvolvimento econômico capitalista:

"Estado de bem-estar" ou "desenvolvimento desde dentro" para as economias latino-americanas.

- Neoliberalismo (a partir de 1980), domina o cenário internacional.

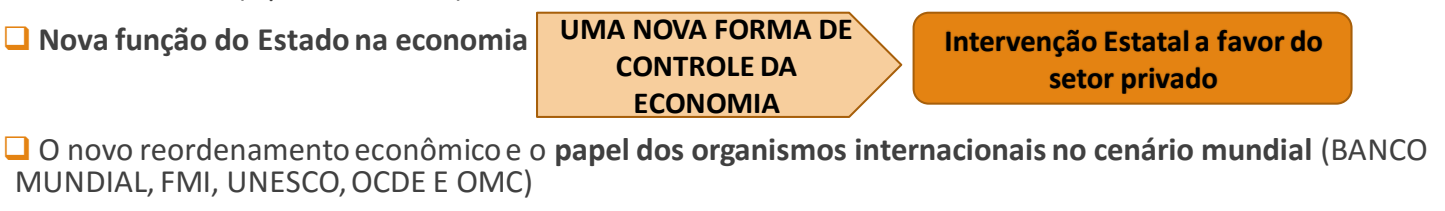

Fonte: Elaborado pela autora

Segundo a literatura (ANDERSON, 1995; CHESNAIS, 2015; ROSARIO, 2010), o neoliberalismo, fundamentado no liberalismo clássico, defende um Estado não protecionista que favoreça a livre competência e que possibilite a auto regulação "natural" da economia; defende também uma liberdade absoluta do mercado para a formação e reprodução do capital. Desde essa visão, estas medidas possibilitariam o emprego adequado do capital na produção, com efeitos positivos na produtividade, eficiência e competividade das empresas e nações, e logo no crescimento econômico e na distribuição da riqueza social. A liberdade ao mercado pregoada pelos neoliberais, envolve políticas de liberalização e desregulação econômica e financeira, que eliminam o monopólio do Estado para fornecer os serviços públicos.

Segundo Chesnais (2015), três são os princípios neoliberais, suporte ideológico da mundialização do capital, e materializados nas políticas econômicas nacionais 
desde os anos noventa (principalmente) até agora. "Liberalização, desregulação e privatização são as plataformas da mundialização do capital contemporâneo." (Ibid., p.1, tradução nossa) $)^{9}$. Neoliberalismo no plano político e mundialização do capital no plano econômico (NEVES; SANT'ANNA, 2005) aparecem no cenário internacional como dois fenômenos interligados (CHESNAIS, 2015), ver figuras 2 e 3.

\section{Figura 4 - Os princípios políticos}

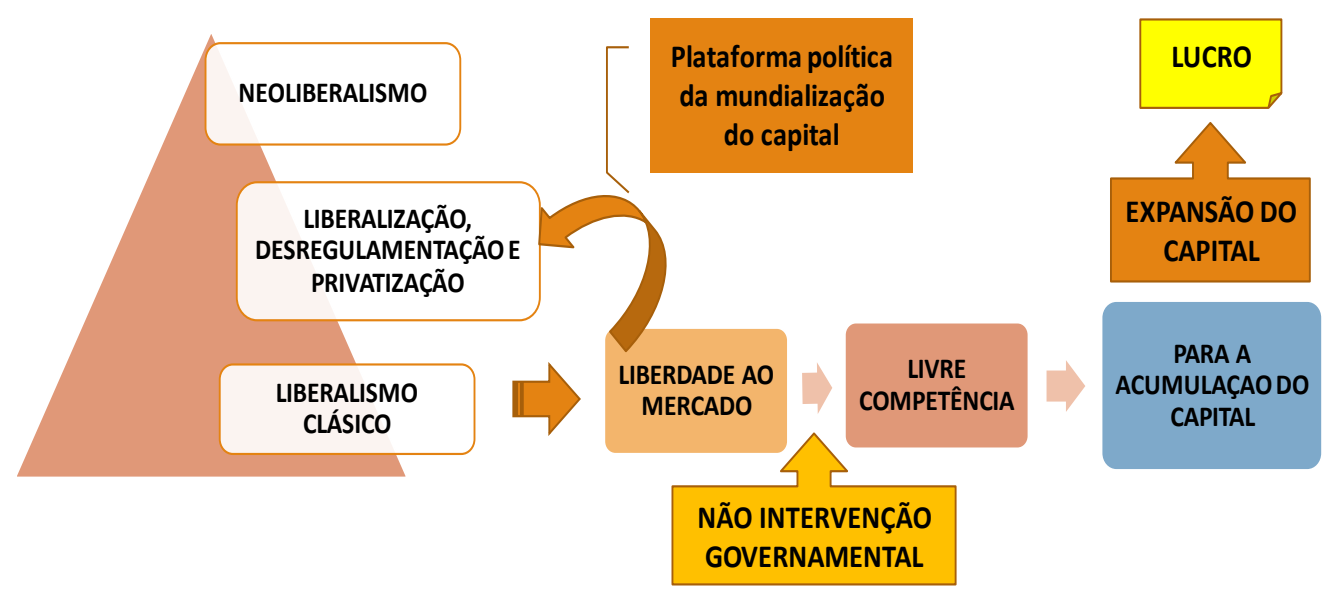

Fonte: Elaborado pela autora

Figura 5 - Os princípios econômicos

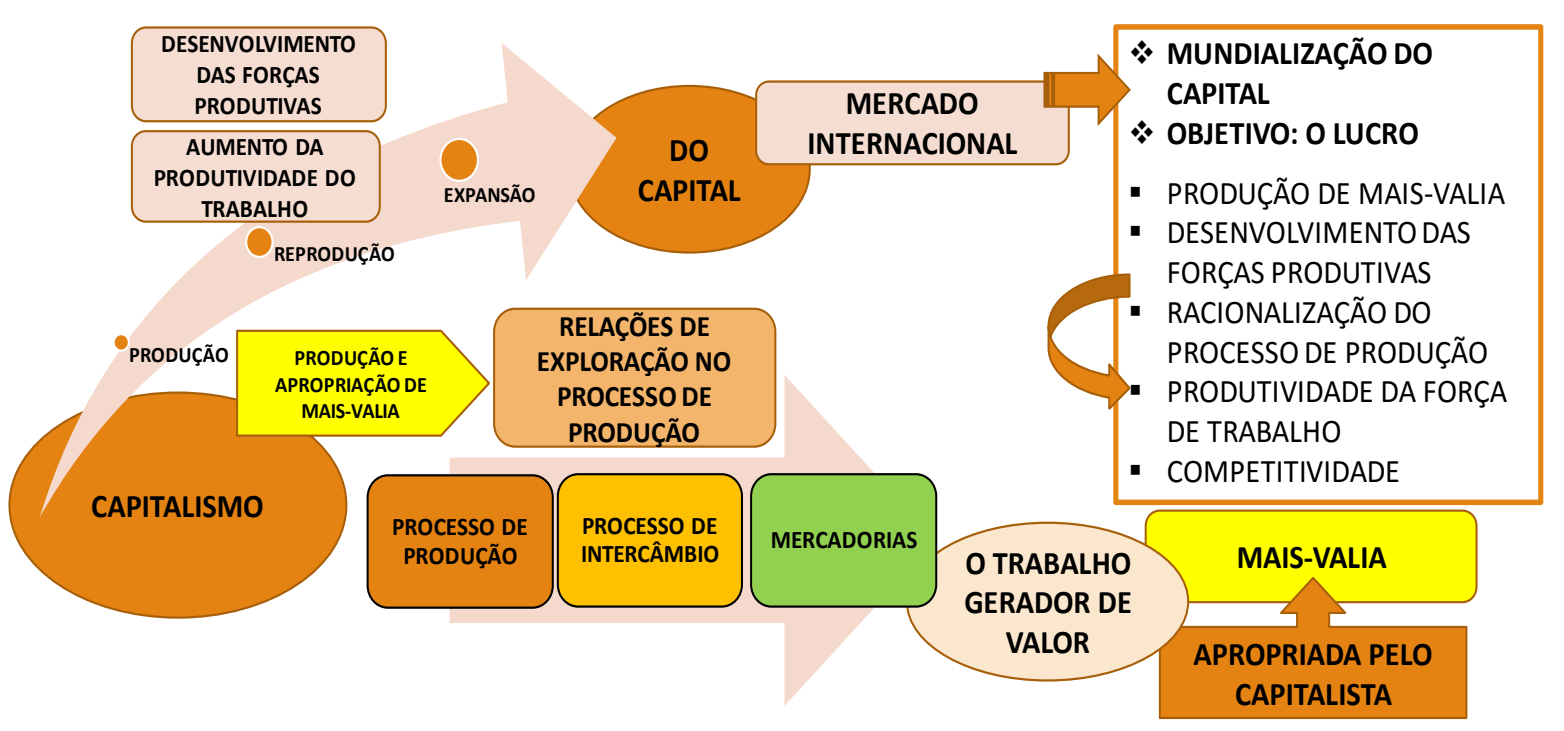

Fonte: Elaborado pela autora

9 Liberalización, desregulación y privatización son la plataforma de la mundialización del capital contemporáneo. 
Para compreender a mundialização do capital, é preciso retomar a análise do modo de produção capitalista de Marx. Segundo este autor (MARX, 1988; 1975a; 1975b), a riqueza destas sociedades se constrói no processo de produção e de intercâmbio das mercadorias ${ }^{10}$. Isto é, na produção de um produto com duplo valor: um valor-de-uso, que é a utilidade (em quanto satisfaz as necessidades humanas) e um valor-de-uso social, que representa a troca desse produto útil no mercado.

As mercadorias são portadoras de riqueza e valor, na medida em que elas contêm trabalho humano incorporado no seu processo de produção. Porque só o trabalho é aquele capaz de criar valor, que se materializa na produção de um novo valor de uso, que quando destinado a um uso social adquire também um valor de troca. Este valor de troca possibilita o intercâmbio e venda do produto, na forma do dinheiro como equivalente geral, e entanto uma mercadoria só pode ser trocada por outra mercadoria de igual valor, o dinheiro surge como uma mercadoria mais. A finalidade produtiva em uma sociedade capitalista, não é a produção de simples valores-de-uso, mas a produção de valores-de-uso social que contenham valor, isto é, a produção de mercadorias (MARX, 1988).

Para Marx (Ibid., p. 223), o conceito de trabalho tem que ser compreendido como uma atividade exclusivamente humana, como aquela orientada a uma finalidade determinada: à produção social de bens necessários para sua vida. É nesse processo social, que o homem age conscientemente sobre a natureza para apropriar-se dos materiais (objeto de trabalho); para elaborar os instrumentos ou meios de trabalho que Ihe permitem transformar o objeto de trabalho (se for o caso) para atingir seu objetivo. O homem estabelece com seu trabalho uma relação de mediação com a natureza.

\footnotetext{
O trabalho é primeiramente um processo entre o homem e a natureza, um processo em que o homem medeia, regula e controla seu metabolismo com a natureza. O homem [...] Põe em movimento as forças naturais que pertencem a sua corporeidade, braços e pernas, cabeça e mãos, para apoderar-se dos materiais da natureza sob uma forma útil para sua própria vida. (MARX, 1988, p. 215, tradução nossa).
}

10 "Para a sociedade burguesa a forma de mercadoria, adoptada pelo produto do trabalho, ou a forma de valor da mercadoria, é a forma celular econômica." (MARX, 1988, p. 6, tradução nossa). 
A natureza não é apenas necessária neste processo criativo e produtivo, para Marx ela é fundamental. A natureza é a mãe de tudo aquilo que existe ${ }^{11}$, e em quanto natureza corporificada, o homem por meio do seu trabalho entra em contato com a natureza externa, atuando à vez em se mesmo, na sua própria natureza interna. Transformando a natureza externa, ele transforma ao mesmo tempo sua "própria natureza" (MARX, 1988, p. 216). O homem com seu trabalho cria-se a se mesmo, é aqui a importância do trabalho e seu caráter ontológico constitutivo do ser humano (LEONTIEV, 1978).

Os produtos de caráter sócio histórico, resultados do processo de trabalho, são apropriados pelos homens na sua interação social. Segundo Vigotski (2015) e Rubinstein (1973), a produção e apropriação destes produtos materiais e espirituais são condição para o desenvolvimento das funções psicológicas superiores e da personalidade dos homens.

É neste trabalho produtivo que o homem se organiza, estabelecendo relações sociais de produção e uma divisão social do trabalho (a partir da propriedade sobre os meios de produção) que determinarão o modo de produção, que Marx chama de estrutura econômica. É sobre esta base que se erige a "[...] superestrutura jurídica e política e à qual correspondem determinadas formas de consciência social." (MARX 1977, p. 24). A consciência é, portanto, produto dessas relações sociais, em quanto reflexo do social (como representações sociais subjetivas) e em quanto prática social (LEONTIEV, 1984).

A divisão do trabalho possibilitou que os produtos dos homens se transformassem em mercadoria, e no capitalismo, a força de trabalho -criadora de valor- que para Marx (1988) é o trabalho vivo ${ }^{12}$, transforma-se também numa mercadoria que, mediante um contrato laboral o próprio trabalhador "livre", vende-se por um tempo determinado ao possuidor dos meios de produção (e, portanto, do dinheiro, do capital) para assim obterem seus meios de subsistência (lbid., p. 205). É aqui uma caraterística importante do capitalismo, a alienação do trabalho ao capital, como uma categoria histórica que nos explica a "forma mercantil" do trabalho e "dos produtos do trabalho" (MARX, 1988, p. 207). Essa categoria econômica explica o que

\footnotetext{
11 "O trabalho, por tanto, não é a fonte única de produção dos valores de uso, da riqueza material. O trabalho é o pai desta, como diz William Petty, e a terra, sua mãe." (MARX, 1988, p. 53, tradução nossa). 12 "A força de trabalho só existe como faculdade do indivíduo vivo." (MARX, 1988, p. 207, tradução nossa).
} 
acontece realmente dentro da "esfera de circulação ou do intercâmbio de mercadorias" (MARX, 1988, p. 214), dentro dessas relações sociais de produção; relações que estão ao serviço da classe social detentora dos médios de produção (MARX, 1988, p.8).

A alienação é a "[...] transferência da propriedade de alguém para outra pessoa [...]." (KANT apud MÉSZÁROS, 2006, p. 38) mediante uma "liberdade contratual" que é "[...] (na realidade, a abdicação contratual da liberdade humana) [...]." (MÉSZÁROS, 2006, p. 38). No capitalismo, "A venda é a prática da alienação." (MARX apud MÉSZÁROS, ..., p. 39). Citando a Mészáros (lbid., p.39):

A alienação caracteriza-se, portanto, pela extensão universal da "vendabilidade" (isto é, a transformação de tudo em mercadoria); pela conversão dos seres humanos em "coisas", para que eles possam aparecer como mercadorias no mercado (em outras palavras: a "reificação" das relações humanas); e pela fragmentação do corpo social em "indivíduos isolados" [...], que perseguem seus próprios objetivos limitados, particularistas, "em servidão à necessidade egoísta", fazendo de seu egoísmo uma virtude em seu culto da privacidade.

Como qualquer outra mercadoria, a força de trabalho tem um valor de uso, que possui a característica de produzir um excedente; e tem um valor de troca, que é o pagamento que recebe ao finalizar seu trabalho (MARX, 1988, p. 211).

O valor da mercadoria força de trabalho determina-se da mesma forma que todas as mercadorias (MARX, 1988, p. 207). O valor de uma mercadoria é medido pela "quantidade de trabalho" empregada por cada uma das forças de trabalho individuais na sua produção, ou seja, pelo tempo de trabalho socialmente necessário para produzi-las; que "[...] é aquele exigido para produzir um valor-de-uso qualquer, nas condições normais de produção existentes em uma sociedade e com um grau social médio de destreza e intensidade de trabalho." (MARX, 1988, p. 48, tradução nossa) ${ }^{13}$.

No caso da mercadoria força de trabalho, como trabalho vivo, o seu valor estipula-se também pelo tempo de trabalho socialmente necessário para sua reprodução, para a compra dos meios de subsistência do trabalhador e de sua família. E portanto:

\footnotetext{
${ }^{13}$ El tiempo de trabajo socialmente necesario es el requerido para producir un valor de uso cualquiera, en las condiciones normales de producción vigentes en una sociedad y con el grado social medio de destreza e intensidad de trabajo.
} 
[...] o tempo de trabalho socialmente necessário para a produção da força de trabalho resolve-se no tempo de trabalho necessário para a produção desses meios de subsistência, isto é, o valor da força de trabalho é o valor dos meios de subsistência necessários para a conservação do possuidor daquela." (MARX, 1988, p. 207, tradução nossa).

A quantidade de valor de uma mercadoria varia dependendo do grau de desenvolvimento alcançado pela força produtiva do trabalho, determinada por um conjunto de fatores tais como: "[...] o nível médio de destreza de cada operário, do estádio de desenvolvimento em que encontram-se a ciência e suas aplicações tecnológicas, a coordenação social do processo de produção, a escala e a eficácia dos médios de produção, as condições naturais." (MARX, 1975b, p. 976, tradução nossa). Por conseguinte, esta força produtiva expressaria "[...] o grau de eficácia de uma atividade produtiva orientada a um fim". (MARX, 1975b, p. 983, tradução nossa).

Assim, quanto maior seja o grau de desenvolvimento alcançado pela força produtiva do trabalho, menor será o tempo de trabalho consumido no processo de produção de uma mercadoria; reduzidos o tempo e a quantidade de trabalho incorporados nela, menor será o seu valor expressado no preço para seu intercâmbio.

Conforme o homem tem aumentado seu conhecimento e experiências sobre sua própria natureza, sobre o mundo que o rodeia, das leis naturais que regem essas duas naturezas, as forças produtivas materiais têm-se desenvolvido social e historicamente. $\mathrm{O}$ estado das forças produtivas corresponde a um determinado espaço de tempo e a uma concreta organização econômica, no seio da qual têm-se desenvolvido esses avances filosóficos, científicos, tecnológicos, econômicos, políticos e ideológicos ${ }^{14}$. Quanto mais uma sociedade progride economicamente, suas forças produtivas desenvolvem-se. O desenvolvimento da força produtiva em conjunto com a divisão social do trabalho, têm possibilitado o aumento da produtividade do trabalho. Porém no capitalismo esse conhecimento social é apropriado pela classe hegemónica contribuindo à "estratificação da cultura" e a desigualdade econômica e social dentro e entre as nações (LEONTIEV, 1978, p. 276).

\footnotetext{
14 "Os principais 'instrumentos' do progresso científico são de ordem intelectual (e até político), metodológico, e Engels escreveu que os 'instrumentos intelectuais' não tem nascido da nada, eles não são inatos no homem, senão que eles os têm adquirido, têm-se desenvolvido e se desenvolvem historicamente." (GRAMSCI, 2009, p.58).
} 
No modo de produção capitalista, as relações de produção caracterizam-se por serem de exploração de uma classe social que detêm o poder econômico e os meios de produção (capitalistas), sobre outra que possui apenas sua força de trabalho como único meio de sobrevivência (trabalhadores). No processo de produção, quando o capitalista compra a força de trabalho, apropria-se do valor de uso, e à vez do produto resultado desse trabalho, materializado como outro valor de uso. Porém, nesse processo de produção não existe apenas um processo de formação de valor (produção de mercadorias) mas também um processo de valorização. O homem com seu trabalho reproduz seu valor de troca e produz além disso, um valor excedente que não é pago pelo capitalista mas que é apropriado por ele.

Destaca-se desta forma, uma relação econômica desigual, uma relação de exploração expressada como a "[...] apropriação do produto do trabalho alheio." (MARX apud PARO, 2014, p.46).

Esse excedente, que Marx chama de mais-valia, é o principal incentivo econômico para produzir. A produção de mais-valia e sua apropriação pelos capitalistas é a principal característica do capitalismo ${ }^{15}$. Retomamos a explicação de Paro (2014) ao respeito:

\footnotetext{
Ao comprar meios de produção e força de trabalho, o capitalista tem por finalidade a valorização de seu capital. Seu objetivo último é a produção de mais-valia. Só assim ele consegue ter seu capital ampliado. Mas essa expansão do capital só se dá, [...], pela exploração do trabalhador. (MARX apud PARO, 2014, p.58).
}

Marx identifica dois momentos num mesmo processo de trabalho em que são criados um valor e um valor excedente (mais-valia). Na primeira fase deste processo que Marx denomina de tempo de trabalho necessário, "[...] o operário limita-se a produzir o valor da sua força de trabalho, isto é, o valor dos meios necessários de subsistência" (MARX, 1988, p. 260, tradução nossa); numa segunda fase desse mesmo processo, que Marx identifica como tempo de trabalho excedente, o consumo da mesma força de trabalho prolonga-se além do tempo de trabalho necessário para sua reprodução, gerando um mais-trabalho que produz um mais-valor. O processo de trabalho situasse só como o meio para a produção da mais-valia (o fim). (MARX apud PARO, 2014, p. 58).

15 Ver Paro (2014) também. 
Nos inícios do capitalismo, a extração de mais-valia dava-se com a extensão da jornada de trabalho e com o aumento da intensidade de trabalho. As condições de trabalho eram simplesmente inumanas, crianças e adultos trabalhavam até 12 horas diárias (MARX, 1988, p. 335) em situações insalubres. Esta produção de mais-valia absoluta é a "[...] expressão material da subsunção formal do trabalho ao capital" (MARX apud PARO, 2014, p. 62), que é "[...] a forma social pela qual se realiza a subordinação do trabalho ao capital." (PARO, 2014, p. 61).

Posteriormente, com as lutas sociais pelos direitos dos trabalhadores, conseguem-se legislações que regulam a produção e a redução das jornadas de trabalho (MARX, 1988). O capitalista opta por expandir seu capital, aumentando a produtividade e eficiência laboral via a introdução de tecnologia moderna e da reorganização do processo de trabalho. Trata-se de elevar a produtividade com "[...] o aumento relativo do tempo de trabalho excedente, mas pela redução do tempo de trabalho necessário. [...] A mais-valia decorrente dessa redução do tempo de trabalho necessário é chamada de mais-valia relativa." (MARX apud PARO, 2014, p. 63).

Como vimos, o desenvolvimento das forças produtivas, a geração e uso de novas tecnologias, a organização do processo produtivo, assim como a introdução de novos processos ou produtos, principalmente, têm como resultado a elevação da produtividade do trabalho. O tempo de trabalho necessário para a produção de mercadorias diminui, e do mesmo modo reduzem-se o valor das mercadorias, incluída a força de trabalho (MARX, 1975a).

Esta racionalização do trabalho para o incremento da produtividade e da eficiência conseguisse com a parcelarização das atividades de um mesmo processo de produção. A "divisão pormenorizada do trabalho" ou "divisão técnica do trabalho" (MARX, 1975a) é uma forma mais de controle e de "subsunção real" do trabalho ao capital, entanto o homem encontra-se preso num espaço, com uma atividade rotineira, guiado e subordinado por uma maquinaria, representação do capital. Em palavras de Peixoto (1995, p. 43), "O trabalho assume um caráter eminentemente mecânico, abstrato, indiferente e destituído de sentido."

Esta subsunção real conseguisse também com o controle gerencial dos trabalhadores e, por conseguinte com a divisão entre eles em questões de cooperação e solidariedade na luta dos seus direitos laborais. $O$ fato de que existam distinções hierárquicas e diferencias de salários entre os trabalhadores, resulta numa diferença de interesses e posturas da classe operária face a exploração capitalista. 
Quando o homem participa apenas de uma pequena parte do ciclo produtivo, como simples apêndice de uma máquina em um processo produtivo, perdendo de vista os objetivos, planejamento e resultados de todo o processo; quando se cinde cada vez mais o trabalho entre o manual e intelectual; intensifica-se sua alienação.

A fragmentação do trabalho em atividades simples, possibilita ao capitalista comprar a baixo custo e de maneira diferenciada a força de trabalho dependendo das habilidades e competências que precise essa atividade em questão. Os capitalistas não precisam de homens com uma educação integral nem com a consciência sobre seus direitos fundamentais, logo, o sistema educacional capitalista assumirá a responsabilidade por brindar educações diferenciadas, em que uma esteja voltada à uma formação privada e privilegiada, outra a uma formação pública e outra ao "[treinamento] para uma certa especialidade" (VIGOTSKI, 2015, p. 4) ou formação técnica, encaminhada para o mercado laboral. Esta última é uma educação que mutila ao ser humano, o escraviza a vida toda a uma atividade e a um domínio (lbid). Leontiev (1978) refere-se a esta situação como a estratificação de uma mesma cultura, em que a classe dominante se apropria do conhecimento produzido social e historicamente, e "O choque destas duas tendências provoca aquilo a que se chama a luta ideológica." (Ibid, p. 276) e que Marx chamou de luta de classes.

Enquanto à subsunção real do trabalho, Marx (1975a, p. 440) menciona como em nome da "riqueza social", "wealth of nations" ou do progresso econômico - fazendo alusão à obra de Adam Smith (1999) -, se explora a tão grau ao trabalhador que lhe provoca não apenas um desgaste físico e um empobrecimento econômico, mas também espiritual. É aqui outra finalidade dos capitalistas, desagregar ao espírito humano para sua dominação.

A competitividade das empresas, reside no valor das mercadorias (incluindo a força de trabalho). É no processo de circulação que o valor das mercadorias se materializa adquirindo sua forma mercantil de preço ${ }^{16}$, neste caso um preço competitivo que lhe permite ao capitalista competir com outros capitais no mercado e à vez expandir continuamente seu capital, incrementando desta forma seus ganhos, objetivo último do capitalismo.

16 "O preço é a denominação monetária do trabalho objetivado na mercadoria." (MARX, 1988, p.124, tradução nossa). 
A subsunção real the permitirá racionalizar ${ }^{17} 0$ processo de produção, eliminando desperdícios de recursos ${ }^{18}$, e reduzindo custos (entre eles os custos salariais), graças à:

[...] elevação na produtividade do trabalho advinda do aproveitamento máximo da matéria prima, da redução no desgaste dos instrumentos de produção e do emprego adequado da ciência e tecnologia na invenção e aperfeiçoamento de máquinas e ferramentas, bem como na divisão do trabalho orientada para a produtividade máxima. (PARO, 2014, p. 73).

Para os capitalistas, a redução dos custos de produção (tanto dos meios de produção como da força de trabalho), financeiros e de transporte (entre outros) são necessários para manter-se num mercado cada vez mais competitivo. Para sustentar esta dinâmica capitalista, de produção e expansão do capital, a chamada mudança tecnológica, motivada pela competência entre as empresas é indispensável (MARX, 1988; SMITH, 1999).

A mudança tecnológica como parte da teoria económica, tem seus inícios com a síntese neoclássica nos anos cinquenta como parte do debate teórico sobre o crescimento econômico (SÁNCHEZ, 2000). Abramovitz (1956) numa tentativa por explicar o crescimento dos Estados Unidos concluía que as causas dos incrementos na produtividade não eram apenas o resultado do trabalho e do capital (ARCHIBUGIE; MICHIE, 1998). Um ano mais tarde em 1957, o trabalho de Solow (1990) explicaria os incrementos da produtividade dos Estados Unidos (para o período de 1909-1949) com um residual que ele chamou de "mudança técnica".

O crescimento econômico para a teoria neoclássica seria explicado pela acumulação de capital, pela intensificação do fator produtivo "recurso humano", chamado também de "capital humano" (entendido como os conhecimentos, habilidades e competências incorporadas nas pessoas), e pelas mudanças tecnológicas, que é o avanço do conhecimento e da técnica materializadas em

\footnotetext{
17 "uma organização é racional se os meios mais eficientes de uma organização são escolhidos para a implementação das metas. No entanto, são as metas coletivas da organização [leia-se: do capital] e não as dos seus membros individuais que são levadas em consideração. Deste modo, o fato de uma organização ser racional não implica necessariamente que seus membros ajam racionalmente no que concerne às suas próprias metas e aspirações. Muitas ao contrário, quanto mais racional e burocrática se torna uma organização, tanto mais os membros individuais se tornam simples engrenagens de uma máquina, ignorando o propósito e o significado de seu comportamento." (CHIAVENATO, apud PARO, 2014, p.73).

18 "[...] a utilização racional dos recursos [...]."(PARO, 2014, p.72).
} 
maquinarias, produtos e processos que elevam a produtividade do trabalho e dos insumos. Condições estas para a competitividade das empresas e países.

Resumindo, a competência entre os diferentes capitais é o principal motivo para que se invista fortemente em ciência e tecnologia (C\&T), inovação e gestão empresarial, políticas internas encaminhadas ao aumento da produtividade e a redução dos custos econômicos e financeiros.

Com a criação de novos produtos, a introdução de novos processos de produção (geração de novas tecnologias), transforma-se a estrutura produtiva e organizativa das empresas, e modificam-se as estruturas tecnológicas até então existentes. Este processo dinâmico conhece-se como mudança tecnológica (CAPDEVIELLE, 2000).

A mudança tecnológica é vista por conseguinte como um esforço tecnológico endógeno, em que as políticas públicas desempenham um papel determinante na conformação das capacidades tecnológicas. No nível microeconômico, estas mudanças incidem na produtividade, eficiência e competitividade das empresas assim como das instituições públicas e privadas, todos eles considerados como agentes econômicos (DOSI, 1991).

A nível macroeconômico estas capacidades tecnológicas promoveriam o crescimento econômico e um desenvolvimento econômico ao longo prazo, e consequentemente uma competitividade internacional (ABOITES, Jaime, 1998; MOZAMMEL, 1998; RADOSEVIC, 1999). Os efeitos de grande alcance econômico que sugere a literatura sobre a mudança tecnológica, é o motivo pelo qual os países e empresas investem fortemente nesta área.

A lógica empresarial instala-se no público, e o Estado capitalista, organização política no domínio da superestrutura, assumirá uma nova forma de intervenção, regulando as relações econômicas, promulgando políticas industriais que incentivem a acumulação de capital, mediante leis laborais flexíveis, apoios aos esforços tecnológicos das empresas, e mudanças na "capacitação" da população. Tudo isto com o discurso de modernidade produtiva e nacional, de benefício social. O Estado capitalista ao serviço da classe hegemônica ${ }^{19}$ como domínio do público, "proclamase" de interesse social (POULANTZAS, Nico, 2015).

\footnotetext{
19 "Nas sociedades capitalistas, o poder emana das relações sociais de produção na sociedade civil (estrutura) e é exercido pelo Estado, ou sociedade política (superestrutura política), forma ético-política
} 
Partindo do fato de que as atividades inovadoras eram geradas substancialmente nos países desenvolvidos e não assim nos países em desenvolvimento (DOSI, 1991), nos anos oitenta inicia-se a discussão sobre a geração das capacidades tecnológicas nas empresas e nos países, que consiste na promoção de certos conhecimentos e habilidades nos trabalhadores, necessários para a aquisição, assimilação, uso e adaptação da tecnologia, assim como para a direção da mudança tecnológica e da criação (inovações). A falta destas capacidades, faz que os países em desenvolvimento cubram a parte tecnológica através da transferência tecnológica (TT) internacional. (ABOITES, Jaime, 1998; MOZAMMEL, 1998; RADOSEVIC, 1999).

Mokyr, citado em Radosevic (1999, p. 97), menciona a importância que tem também a "acumulação tecnológica nacional" que consiste no desenvolvimento de capacidades como a organizacional, desenho e engenheira, assim como a criação de uma infraestrutura que permita desenvolver localmente a C\&T como a investigação e desenvolvimento (I\&D). Enquanto os evolucionistas ${ }^{20}$ (FREEMAN, 1995; LUNDVALL, 2000) propõem o conceito de Sistema Nacional de Inovação (SNI) que faz referência a todos aqueles elementos e agentes (conjunto de empresas e instituições) num país que interagem de maneira conjunta ou individual e que conduzem à conformação de redes de cooperação e competência, nas quais desenvolvem-se e geram-se as inovações. As políticas públicas são de grande importância para que se estabeleçam essas relações. Este conceito leva implícito a conformação das capacidades tecnológicas que facilitariam o aprendizado nos países em desenvolvimento.

A geração de conhecimento para o desenvolvimento da tecnologia, posicionase como política pública prioritária como solução dos problemas econômicos e sociais via a competitividade das empresas e das instituições públicas. Deixa-se de lado a análise crítica do funcionamento do sistema econômico como germe das desigualdades econômicas e sociais, dentro dos países e entre os países (SAVIANI, 2008). Precisa-se de um Estado forte que regule as políticas que favoreçam a

de garantia da dominação da classe expropriadora sobre a classe expropriada ou trabalhadora." (NEVES; SANT'ANNA, 2005, p. 21).

${ }^{20}$ Segundo Dosi (1990), Archibugi e Michie (1998) pode-se dividir em dois grandes grupos os trabalhos sobre mudança tecnológica no pensamento econômico, em que por um lado encontramos à escola neoclássica com estudos que centram-se principalmente no crescimento econômico e o comercio; e por outro lado, um grupo bastante eclético que nós conhecemos como a escola evolucionista, que se apoia em estudos de Smith, List, Marx e Schumpeter (ARCHIBUGI; MICHIE, 1995, 1998; DOSI, 1990; PAVITT, 2001). 
expansão das empresas e a implementação de políticas gerenciais nos setores públicos (CHESNAIS, 2015; BALL; YOUDELL, 2007).

A busca de novos mercados além do território nacional não é um fenômeno contemporâneo, está presente desde os inícios do comércio, a caraterística da mundialização do capital consiste na intensificação desses intercâmbios sob os postulados neoliberais: uma expansão sem barreiras comerciais, jurídicas, geográficas, para "[...] a disposição de capitais e mercadorias, como de melhores condições nacionais e regionais para a acumulação." (ESTAY, 1993, p. 40, tradução nossa). A liberdade que estes fluxos econômicos e financeiros têm adquirido, têm levado a uma integração da economia internacional e à conformação de bloques regionais supranacionais como o Tratado de Livre Comércio com América do Norte (TLCAN), a União Europeia (UE) e o Mercado Comum do Sul (MERCOSUL), encaminhadas a intensificar essas relações comerciais. A Organização Mundial do Comércio $(\mathrm{OMC})$ é a instituição internacional encarregada de liberalizar e regulamentar o comércio entre os países membros com tratados econômicos, jurídicos e políticos dirigidos a eliminar a desregulamentação e regulação governamental em todos os setores da economia. Desde a ótica neoliberal, o incremento da competência promoveria a competitividade internacional, mas como sinalamos acima, esta é uma estratégia mais para a ampliação do capital (ABOITES, Hugo, 2007).

A educação considerada pelos neoliberais como um serviço e uma mercadoria, forma parte das políticas comerciais da $\mathrm{OMC}^{21}$. A educação é vista como um grande mercado estável e em expansão, que representa uma grande oportunidade de negócios para qualquer investidor. Segundo Aboites Hugo (2007, p. 28), desde 1985 o comércio de serviços cresce mais rapidamente que o comércio de mercadorias, esta expansão observa-se sobretudo na educação a distância.

Citamos a continuação a explicação de Aboites Hugo (lbid.) sobre as bondades que tem o mercado educacional para o capital:

[...] a educação formal é uma das atividades mais intensivas que existem, ela involucra a centenas de milhões de pessoas e igual número de famílias, cinco dias à semana e praticamente o ano todo. Ela é também extremamente variada e com muitas facetas e, além de longa duração (pelo menos os seis

21 "Embora trate-se de negociações e compromissos entre os governos, em alguns países, estes pactos são ratificados no Congresso e conseguem adquirir o status de Leis constitucionais." (ABOITES, Hugo, 2007, p. 32, tradução nossa). 
ou nove anos de educação básica). E finalmente, ela é uma das atividades consideradas mais importantes em sociedades como as latino-americanas. Se vale a pena investir -pensam muitos pais de família- é em educação. (Ibid, p. 29, tradução nossa).

A propriedade intelectual, os produtos da ciência e da investigação, e em geral o conhecimento produzido social e historicamente está sendo apropriado cada vez mais pelas grandes empresas. Existem modernos mecanismos de proteção à tecnologia e ao conhecimento impulsionados pela OMC, assim como tratados de livre comercio que possibilitam o livre trânsito do chamado "capital humano" (visto como o conhecimento materializado nos trabalhadores e conhecido também como "capitalconhecimento"), desta forma, os grandes consórcios conseguem mobilizar a seus trabalhadores, entre suas filiais localizadas em diferentes países (ABOITES, Hugo, 2007). A competitividade das empresas nesta fase do capitalismo, destaca-se pelo nível de mudança tecnológica alcançada por elas e pela comercialização de alta tecnologia. O conhecimento como fator produtivo tem um valor comercial de suma importância para o capital.

A década dos noventa identificou-se pelo aumento da atividade econômica internacional, em que as empresas transnacionais principais protagonistas (ETN) têm registrado uma grande expansão mediante as fusões e aquisições (CHESNAIS, 2015; ESTAY, 1997). Elas são as principais condutoras dos fluxos de investimento estrangeiro direto (IED), da produção internacional e comercial de bens e serviços (lbid.), em que a educação como uma mercadoria está presente. A respeito, Chesnais (2015) nos diz que "[...] a [IED] com destino aos países em via de desenvolvimento tem sido um dos elementos do movimento mundial de centralização e concentração de capital." (Ibid., p. 5, tradução nossa) ${ }^{22}$.

O IED é um dos melhores indicadores da presença desses agentes econômicos em um país receptor e é portanto, o indicador por excelência da mundialização do capital. Devido aos altos custos que pressupõe a mudança tecnológica para os países em desenvolvimento, o IED representa para estes países um veículo de transferência tecnológica (TT), para conseguir e absorver por esta "via rápida" a tecnologia, as inovações em processos e produtos, necessários para o funcionamento do aparato produtivo e para sua competitividade (DUNNING, 2001).

\footnotetext{
22 [...] la IDE hacia los países en vías de desarrollo ha sido uno de los componentes del movimiento mundial de centralización y concentración de capital.
} 
Mas como comentamos, a tecnologia encontra-se protegida por leis de propriedade intelectual que fazem difícil sua apropriação. Segundo os evolucionistas (ARCHIBUGI; FREEMAN, 1995; LUNDVALL, 2000; MICHIE, 1998; DOSI, 1991; PAVITT, 2001) o conhecimento e a tecnologia são de propriedade privada, têm um preço e representam um lucro para as empresas que as possuem. O conhecimento tecnológico caracteriza-se por estar codificado ${ }^{23}$ e por ser "adquirido" ao longo de um processo de aprendizagem, logo, tem um caráter histórico e local que dificulta sua transferência de uns países a outros. Assim, a apropriação tecnológica pelos países desenvolvidos via a TT não é mecânica nem automática.

Para González (2000), este "reordenamento econômico" caracterizado por "A integração de mercados, de finanças e de tecnologia [...]" tem constituído "[...] uma nova divisão internacional do trabalho" (Ibid., p. 568), como resultado das novas formas de organização produtiva (produção flexível) que levam a essas integrações inter e intra-regionais, como inter e intra-sectoriais. A educação no neoliberalismo considerado como um serviço e mercadoria, participa como comentamos, nesta lógica produtiva.

As grandes mudanças tecnológicas dos anos oitenta e a reestruturação empresarial, em termos de novas formas de produção e de acumulação flexível ${ }^{24}$, modificaram a internacionalização do trabalho e das empresas. Com a reestruturação empresarial, estabelecem-se assim, novas relações internacionais do trabalho e do comercio, que configura a nova divisão internacional do trabalho (GONZÁLEZ, 2000; ANTUNES, 2014).

Segundo Antunes (2014) e Dabat (2002), o cenário mundial capitalista dos anos oitenta e noventa, posterior ao modelo keynesiano e ao "padrão fordista de acumulação", abre o "[...] passo à automatização flexível dos processos produtivos [...]" (DABAT, 2002, p. 45, tradução nossa) ${ }^{25}$, e a uma incrível revolução científicotecnológica em áreas como "[...] a eletrônica e a inteligência artificial, a digitalização,

\footnotetext{
${ }^{23}$ Conhecimento que encontra-se em livros, patentes, artigos científicos, etc.

24 "[...] Ela se apoia na flexibilidade dos processos de trabalho, dos mercados de trabalho, dos produtos e padrões de consumo. Caracteriza-se pelo surgimento de setores de produção inteiramente novos, novas maneiras de fornecimento de serviços financeiros, novos mercados e, sobretudo, taxas altamente intensificadas de inovação comercial, tecnológica e organizacional. A acumulação flexível envolve rápidas mudanças dos padrões do desenvolvimento desigual, tanto entre setores como entre regiões geográficas, criando, por exemplo, um vasto movimento no emprego no chamado "setor serviços", bem como conjuntos industriais completamente novos em regiões até então subdesenvolvidas [...]" (HARVEY apud ANTUNES, 2014, p. 28).

${ }^{25}$ paso a la automatización flexible de los procesos productivos.
} 
a robótica, a telemática, o satélite, etc." (GONZÁLEZ, 2000, p. 572, tradução nossa) ${ }^{26}$, a biotecnologia, nanotecnologia, o desenvolvimento de novos materiais não férreos como os plásticos reforçados, "os semicondutores", "as fibras óticas", etc. que tornaram possível uma revolução nas comunicações, facilitando os fluxos de informação e capitais entre países e regiões. Novas tecnologias, que têm diminuído os tempos de produção e aumentado a produtividade das empresas em geral; conectando e reestruturando a nível mundial as relações sociais e econômicas. Esta nova etapa conhece-se como a "sociedade do conhecimento". Vivemos numa sociedade em que o conhecimento e a informação são elementos estratégicos para a competitividade de qualquer empresa ou instituição, e sobretudo para "[...] a acumulação de capital a nível mundial." (GONZÁLEZ, 2000, p.574). As universidade ${ }^{27}$ e a educação em geral, desempenham um papel central nesta nova fase de mundialização do capital, como veremos mais para frente.

Embora a "produção flexível", sistema toyotista da pós-guerra, apresenta-se como uma readaptação gerencial estadunidense, ela se estende a nível mundial "[...] enquanto processo ágil e lucrativo de produção de mercadorias." (ANTUNES, 2014, p. 30), como a nova lógica produtiva, liberalizando para tal efeito, as legislações laborais e econômicas (processo de desregulação econômica).

Os objetivos do toyotismo de produzir aquilo que a demanda ${ }^{28}$ determine e precisa, no menor tempo, com eficiência, eficácia e qualidade total, se efetivam no: "just in time", no método kanban ${ }^{29}$, nos Círculos de Controle de Qualidade (CCQs), no sistema de cero estoque ou estoque mínimo, flexibilização, terceirização, subcontratação, sindicalismo de empresa ${ }^{30}$ e na gestão participativa, em que "[...] o trabalho passa a ser realizado em equipe, rompendo-se com o caráter parcelar típico do fordismo [...]" (ANTUNES, 2014, p. 32).

A "descentralização produtiva", é uma forma de organização espacial da produção, em que as grandes empresas se articulam com as pequenas empresas

\footnotetext{
${ }^{26}$ la electrónica y las nuevas tecnologías de la información y la comunicación como la informática, la inteligencia artificial, la digitalización, la robótica, la telemática, el satélite, etc.

${ }_{27}$ Veja-se González (2000), para um maior conhecimento do tema a respeito do papel que tem a educação superior nesta sociedade do conhecimento.

28 " [...] ao contrário do fordismo, a produção sob o toyotismo é voltada e conduzida diretamente pela demanda. A produção é variada, diversificada e pronta para suprir o consumo, É este quem determina o que será produzido e não o contrário, como se procede na produção em série e de massa do fordismo." (ANTUNES, 2014, p. 33).

29 "[...] o kanban é a senha utilizada que alude à necessidade de reposição das peças/produtos." (ANTUNES, 2014, p. 33).

${ }^{30}$ Para mais informação ver Antunes (2014).
} 
fornecedoras de produtos e serviços, localizadas nas proximidades. Mediante a tecnologia informática e softwares avançados, estabelece-se um contato permanente com a rede produtiva empresarial, evitando estoques ao mínimo, obtendo no tempo preciso as peças e/ou produtos para a montagem e produção. Com esta estrutura produtiva, consegue-se uma redução de trabalhadores e custos, e um aumento na produtividade (ANTUNES, 2014).

A respeito da flexibilização produtiva, laboral e organizativa da empresa, que este sistema de produção requere, Antunes (2014) nos diz que:

\begin{abstract}
Para atender às exigências mais individualizadas de mercado, no melhor tempo e com melhor "qualidade", é preciso que a produção se sustente num processo flexível, que permita a um operário operar com várias máquinas (em média cinco máquinas, na Toyota), rompendo-se com a relação um homem/uma máquina que fundamenta 0 fordismo. E a chamada "polivalência" do trabalhador japonês, que mais do que expressão e exemplo de uma maior qualificação, estampa a capacidade do trabalhador em operar com várias máquinas, combinando "várias tarefas simples" (conforme o interessante depoimento do ex-líder sindical japonês, Bem Watanabe, 1993a:9). Coriat fala em desespecialização e polivalência dos operários profissionais e qualificados, transformando-os em trabalhadores multifuncionais (Coriat, 1992b:41).
\end{abstract}

Esta nova dinâmica produtiva "intensifica a exploração do trabalho" (GOUNET apud ANTUNES, 2014, p.34).

Como pudemos apreciar, o capitalismo oculta sob o lema de competitividade e desenvolvimento econômico, uma exploração laboral e depredação dos recursos naturais cada vez maior, uma homogeneização, estandardização da cultura e das relações sociais, impondo uma ideologia como "[...] modo de vida [...] o individualismo e o consumismo que estende-se à educação com uma oferta mercantil de certificados e diplomas, sob uma educação permanente. Distorce-se o conceito de educação para a vida toda." (GONZÁLEZ, 2000, p. 569, tradução nossa) ${ }^{31}$.

Neste sistema económico tudo está orientado pela produção e venda de mercadorias. Tudo aquilo que possa gerar lucro é suscetível de ser posto em venda. Converte-se em mercadoria tudo que tenha um valor de uso social no mercado. Neste sentido, é importante ter presente a obra de Marx, quem descobriu a essência, dinâmica e caraterísticas do capitalismo e cujas palavras são de grande atualidade:

\footnotetext{
31 [...] modo de vida [...] el individualismo y el consumismo que se extiende a la educación con una oferta mercantil de certificados y diplomas, bajo una pretendida educación permanente. Se distorsiona el concepto de educación durante toda la vida.
} 
Coisas que em si e para si não são mercadorias, como por exemplo a consciência, o honor, etc., podem ser postas em venda por seus possuidores, adotando assim, graças a seu preço, a forma mercantil. É possível logo, que uma coisa tenha formalmente preço sem ter valor. A expressão em dinheiro torna-se imaginaria [...]. (MARX, 1988, p.125, tradução nossa) ${ }^{32}$.

Certificados, diplomas, etc., absolutamente tudo converte-se em mercadoria, mesmo as relações sociais. Saviani (citando a Marx) descreve como neste modo de produção capitalista as "[...] relações -sendo sociais, humanas- apresentam-se como relações entre coisas." (SAVIANI, 2008, p. 229). Nas mercadorias ficam ocultas as relações económicas de inequidade e de exploração do trabalho humano, relações sociais de produção que são necessárias para a sobrevivência do sistema econômico capitalista.

Como bem disse Gramsci (2009), "[...] enquanto exista um Estado-classe [...] não pode existir igualdade política completa e perfeita sem a igualdade econômica." (Ibid., p. 208).

Com esta breve introdução do funcionamento do sistema econômico capitalista neoliberal, passaremos a empreender o esforço de compreender o papel que tem a educação nele, e como a reforma educativa 2013 se insere nos princípios econômicos e políticos do século XXI.

A educação, que tem na escola sua figura institucional, está sendo transformada e desmantelada, do mesmo modo que o resto das instituições sociais. Esta instituição de cunho republicano, público e laico ${ }^{33}$ na maioria dos países latinoamericanos, esteve até os oitenta sob a custódia estatal, sendo um objetivo principal a constituição de "sujeitos de direito" 34.

Saviani (2008), identifica dois momentos históricos na vida da "escola burguesa". Uma fase que ele define como "revolucionária", em que a educação esteve comprometida com a formação de sujeitos criativos, livres, e com esta finalidade ela impulsionou a cultura em todo seu esplendor, entendendo por cultura o saber humano produzido historicamente. Nesta etapa revolucionária a "[...] educação se destinou à

\footnotetext{
32 Cosas que en sí y para sí no son mercancías como por ejemplo la conciencia, el honor, etc., pueden ser puestas en venta por sus poseedores, adoptando así, merced a su precio, la forma mercantil. Es posible pues, que una cosa tenga formalmente precio sin tener valor. La expresión en dinero deviene aquí imaginaria [...]. (MARX, 1988, p.125).

33 Ver Chaui (2003).

${ }^{34}$ Ver Krawczyk (2005).
} 
formação de elites dinâmicas que impulsionaram o desenvolvimento das ciências, das letras, das artes e da filosofia." (Ibid., p. 233). E a fase "conservadora" em que a classe dominante, a burguesia "massificou" e "vulgarizou" a cultura. Aquilo que González (2000) denomina de "empobrecimento" da vida cultural, "[...] que atenta contra a diversidade de entidades e tradições dos povos." (Ibid., p. 569), homogeneizando um modo de vida, de produção e de consumo.

Todavia, é fundamental considerar as contradições no interior do processo educativo. A educação tem potencial para cumprir um papel fundamental na sociedade: a humanização e a constituição de sujeitos livres e cientes (com a apropriação cultural integral dos homens), para sua participação plena na vida social, econômica e política. Porém, a educação capitalista eleva "[...] a um determinado nível cultural e moral, nível (ou tipo) que corresponde à necessidade de desenvolvimento das forças produtivas e, por conseguinte aos interesses das classes dominantes." (GRAMSCI, 2009, p. 209).

A escola cumpre com a função de reprodução do sistema econômico, mas ao mesmo tempo essa instituição representa também um "instrumento de equalização social" (PARO, 2014, p. 143), com um grande poder emancipador que pode pôr em risco os interesses do próprio sistema (ver PARO, 2014; SAVIANI, 2008; KRAWCZYK, 2005). Neste sentido, a atual organização produtiva denominada por Harvey (apud ANTUNES, 2014) de “acumulação flexível”, precisa de controlar também a educação e tirar sua custodia do Estado, para entrega-la em mãos do capital privado.

Educação e poder, educação e luta de classes, são relações que estão presentes neste modo de produção capitalista, relações que explicam a dinâmica que vive o sistema educacional no México.

A reforma do Estado capitalista sustentada na ideia de que a crise gestada nos anos setenta, foi resultado da ineficiente e burocrática gestão Estadual, e não consequência das contradições e inequidades do sistema capitalista (PERONI; OLIVEIRA; FERNANDES, 2009), consistiu em uma diminuição de sua participação na economia.

Nos anos oitenta y noventa, os organismos internacionais como o Banco Mundial, o Fundo Monetário Internacional (FMI) e a Organização para a Cooperação e Desenvolvimento Econômico (OCDE), aplicaram "reformas estruturais" neoliberais nos países latino-americanos que atravessavam por graves problemas fiscais. Como mencionamos no começo deste subitem, estas reformas foram aplicadas em troca de 
empréstimos que endividaram ainda mais a estas economias (com altas taxas de juros que perpetuam as dívidas). Chesnais (2015) menciona como estas políticas neoliberais têm provocado "processos de desindustrialização" nestas economias.

Os trabalhos de dois prêmios Nobel de Economia, Friedrich Hayek e Milton Friedman, permitiram que as propostas neoliberais de liberalização, desregulação e privatização das economias (suporte ideológico da mundialização do capital) ganhassem notoriedade (ANDERSON, 1995; ROSARIO, 2010).

A naturalização da desigualdade entre os homens, de Hayek e a "liberdade" do homem para eleger seu destino, êxito, ou fracasso, de Friedman, o homo oeconomicus em ação, são as ideias que permitiram de uma maneira simplificada, questionar a eficiência do Estado como provedor dos serviços públicos e defensor dos direitos sociais (ANDERSON, 1995; ROSARIO, 2010).

Para os neoliberais, no caso da educação, o Estado monopólico, burocrático e ineficiente é o principal responsável pelos grandes problemas fiscais e educacionais, e resulta ser necessário que o Estado assuma a esfera política que the corresponde e deixe os assuntos econômicos para os agentes com experiência administrativa.

Hayek e Friedman, sublinharam a importância da existência de competitividade nos âmbitos econômicos e educacional, por ela representar o grande incentivo para os "fornecedores" educacionais oferecerem serviços de qualidade ${ }^{35}$, ótimos resultados e satisfações aos "clientes" alunos e pais de família (ROSARIO, 2010).

As forças econômicas e políticas que movimentam este sistema econômico, conseguiram diminuir consideravelmente o papel do Estado "provedor e regulador" 36 na economia, permitindo a liberdade total ao capital (HILL, 2003). Porém Chesnais (2015), Ball e Youdell (2007), assinalam que não existe uma diminuição tal do Estado, existe uma nova forma de controle e uma participação ativa do Estado na desregulamentação de Leis que favorecem às ETNs e aos grandes investidores financeiros. Trata-se de um Estado interventor em favor do capital (CHESNAIS, 2015).

A descentralização e a autonomia (no sentido de liberdade) se apresentam como as opções neoliberais para essa transferência da educação (e de todos os setores públicos) ao capital nacional e internacional (FRIGOTTO; CIAVATTA, 2003).

\footnotetext{
${ }^{35}$ Quando os neoliberais "sugerem" que o Estado deixe de oferecer os serviços públicos, ele pugna pela qualidade, porque "[...] os fornecedores sabem que podem ser dispensados se sua qualidade cair; funcionários públicos sabem que não podem." (OSBORNE \& GAEBLER, apud ROBERTSON; VERGER, 2012, p. 1139).

${ }^{36}$ Ver Krawczyk (2005).
} 
Tratam-se de políticas privatizadoras não sempre evidentes que se ocultam sob os nomes de "reformas e modernização" para introduzir os princípios e as práticas gerenciais na educação, novas formas de financiamento privado (venda dos serviços educacionais), e a livre competência como incentivo para o lucro econômico, os verdadeiros objetivos desse processo (BALL; YOUDELL, 2007). A ideologia neoliberal apropria-se de conceitos caros aos movimentos sociais que historicamente assumiram lutas por ampliação de participação e autonomia.

A Nova Gestão Pública (NGP) por volta dos anos 1980 é aplicada nos países desenvolvidos como Estado Unidos e o Reino Unido, ela é instituída a escala global nos noventa com a finalidade de sanear a administração pública (GARCIA; ADRIÃO; BORGHI, 2009), de modernizar ao Estado para participar competitivamente no novo cenário mundial, "[...] como um meio de superar a pobreza, e a desaceleração econômica, e com base para a construção de economias baseadas no conhecimento." (ROBERTSON; VERGER, 2012, p. 1137).

A OCDE em 1995, descreve esta reestruturação econômica e política "como "o novo paradigma da gestão pública" (apud BALL, 2001, p. 103). Os principais objetivos de esta nova gestão, são a busca da "[...] eficiência, eficácia e qualidade dos serviços [...]" (BALL, 2001, p.104), propósitos que serão possíveis com: a implementação de esquemas flexíveis orientados nos resultados para satisfazer as demandas dos consumidores; o fomento da competência vinculada com disposições contratuais e remunerações laborais baseadas no mérito e no desempenho; a promoção da liberdade dos consumidores para eleger os melhores fornecedores de serviços; à utilização intensiva das tecnologias da informação; uma eficiente administração (exploração) dos "recursos humanos"; a "[...] transferência do gerenciamento para os gestores, a especificação de padrões e indicadores, [...], auditoria e terceirização de uma série de atividades que haviam sido uma parte central do setor público." (ROBERTSON; VERGER, 2012, p.1136); a implementação de processos de descentralização das funções governamentais para as jurisdições locais, com o estabelecimento de parcerias público-privadas (terceirizando áreas importantes deste setor). (BALL, 2001; GARCIA; ADRIÃO; BORGHI, 2009; ROBERTSON; VERGER, 2012).

Para Xavier (1991) o conceito de qualidade total empresarial, presente na gestão escolar, tem que ser entendida como, o conjunto de "princípios e métodos" que exigem um trabalho produtivo em equipe, com o objetivo de "satisfazer" as 
necessidades dos consumidores. Produzem-se os produtos e serviços específicos que exige a sociedade, com altos padrões de qualidade e excelência, que significam "medidas de prevenção" para minimizar os erros, defeitos e custos (racionalização do trabalho), assim como políticas de premiação aos trabalhadores pelo alto desempenho (eficiência) e produtividade. A responsabilidade e a medição do processo produtivo, traslada-se aos próprios trabalhadores. Tanto o trabalho manual como o intelectual encontra-se sujeito ao controle da gerência, que é um trabalhador mais, representante dos interesses do capital. (PARO, 2014).

\section{Figura 6 - Princípios da qualidade total gerencial}

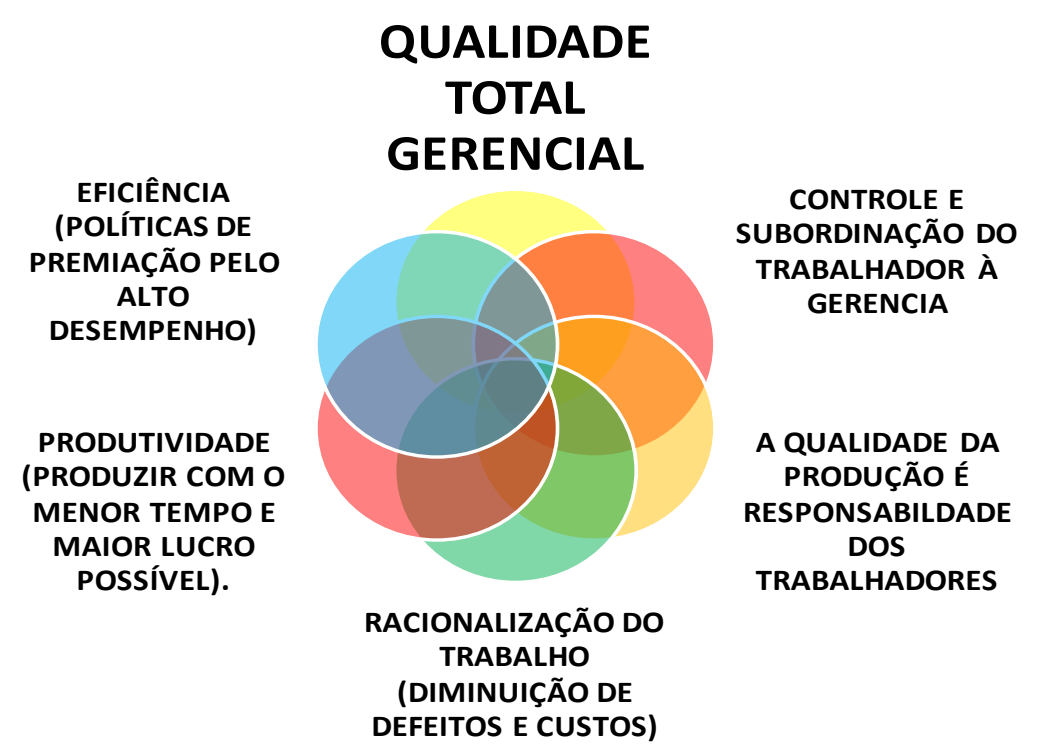

Fonte: Elaborado pela autora

Paro (op. cit.) menciona a importância que tem a figura do gerente para as empresas. Por médio da gerência, controla-se, coordena-se e subordina-se ao trabalhador. Cito textualmente: "A superação do desinteresse do trabalhador e a neutralização de sua resistência às condições de trabalho impostas pelo capital são buscadas por meio da gerência. Esta consiste, essencialmente, no controle do trabalho." (PARO, 2014, p. 79-80).

A gestão escolar, está implementando os princípios do toyotismo, para "reestruturar", "reformar" e "modernizar" a educação. Transferem-se assim os mecanismos de supervisão gerencial, racionalização econômica, flexibilização organizacional, laboral e de qualidade total ao processo educacional. 
A NGP entra no âmbito educacional como "gestão escolar" em que o gestor (o diretor), principal protagonista da reforma (BALL; YOUDELL, 2007), possui o poder de decisão, a liberdade, "autonomia e flexibilidade" "[...] na utilização dos recursos humanos [materiais] e financeiros." (BALL, 2001, p.104) para garantir a qualidade dos resultados. Por outra parte, esta liberalização escolar é no sentido de possibilitar "[...] aos sujeitos escolares de atuarem utilizando seus "próprios" recursos (ideias [sic], desejos, valores, contatos sociais, recursos materiais etc.) pela ausência dos tradicionais recursos normativos e da vocação universalista do Estado na sua política financeira." (KRAWCZYK, 2005, p. 809). A introdução destes mecanismos de mercado na educação, levam a privatização uma vez que se permite a entrada do investimento privado nacional e estrangeiro em todas as áreas públicas. Estes processos mercantis são bastante complexos e não sempre explícitos legalmente, e como comentamos, muitos deles são encobertos sob conceitos políticos, com supostos objetivos de interesse social e nacional (BALL; YOUDELL, 2007; ROBERTSON; VERGER, 2012). Os fluxos de investimento privado permeiam todas as áreas educacionais, mesmo a pedagógica, em que as apostilas para o ensino básico são elaboradas por empresas internacionais.

A educação, "[...] processo pedagógico que tem lugar na escola" (PARO, 2014, p. 184) vem a ser administrada ${ }^{37}$ com objetivos de lucro, e de formação do "capital humano" para as necessidades do mercado, ignorando os objetivos sociais da educação e sua importância na formação integral dos sujeitos. Com a gestão escolar trasladam-se as práticas produtivas e de poder do capitalismo, em que a competitividade, a individualidade, a exploração e as injustiças são naturalizadas, descaracteriza-se assim por completo a função da escola (SILVA, 2001; PARO, 2014; RUSSO, 2004). Sobre a reprodução do sistema capitalista nas escolas, citaremos a Silva (2001) que nos diz:

[...] as desigualdades e injustiças da estrutura existente de poder são reproduzidas cotidianamente em nossas salas de aula. Quando as identidades pessoais e sociais de nossos/as estudantes são forjadas diariamente no interior de relações assimétricas de poder, um discurso que

37 "[...] la actividad administrativa, como proceso que se renueva permanentemente y como instrumento en busca de la racionalidad, no puede dejar de lado el desarrollo de sus principios, métodos y técnicas, los cuales están íntimamente relacionadas con la naturaleza y propósitos de la cosa administrada". (PARO, 2014, p. 178). En el capítulo 4, analizaremos con más detalle la naturaleza de la educación, así como la importancia que juega la administración escolar desde este enfoque que nos presenta Paro, el de la administración en general como una actividad específica y necesaria al hombre, pero que en el capitalismo es puesta al servicio del capital. 
tende a obscurecer precisamente a existência dessas relações só vai tornar mais provável que essas relações sejam reforçadas e reproduzidas. (Ibid., p. 22).

A educação vista como um bem ou serviço, deixa de formar parte do investimento social. Segundo os neoliberais, ela representa um grande custo econômico a ser minimizado, que deve ser portanto, transferido ao mercado e à comunidade. Desde esta lógica neoliberal reduz-se o financiamento público educacional (GARCIA; ADRIÃO; BORGHI, 2009), descentraliza-se a educação para o mercado, e passa a ser considerada como um bem privado e por conseguinte, como uma mercadoria (BALL; YOUDELL, 2007).

A educação nas mãos do neoliberalismo corresponderia à fase conservadora que Saviani (2008) menciona, em que se homogeneízam os objetivos educacionais, a administração e organização do sistema escolar a nível internacional, sem ter em conta as necessidades da sociedade, nem as especificidades de cada país e região. Os objetivos estabelecidos pelos organismos internacionais, são os objetivos que servem ao capital econômico e financeiro.

Como vimos, a gestão da escola é uma das bases da reforma educacional, sob esta figura administrativa, conseguem-se adequar as "decisões políticas" às "decisões do mercado", relações públicas e privadas que precisam de novas modalidades regulamentadoras, como a descentralização e a liberdade ou "[...] autonomia financeira, administrativa e pedagógica- da instituição" (KRAWCZYK, 2005, p. 805).

Nesta associação do público e do privado, nasce o "sector público não-estatal" (GARCIA; ADRIÃO; BORGHI, 2009, p. 15). A incorporação destes "[...] mecanismos gerenciais na gestão pública assume a denominação de quase-mercado. Nesse sentido difere da total privatização dos serviços e incentiva a adoção de novas simbioses entre a esfera pública e privada." (Ibid., 2009, p. 15).

Esta forma de quase-mercado no setor público não-estatal, encobre segundo Ball e Youdell (2007) o principal mecanismo de privatização na educação. Esta é uma "estratégia sutil” (KRAWCZYK, 2005), que diminui as tensões sociais, uma vez que a escola pública continua existindo sob a tutela do Estado. Para que esta permanência pública continue, faz-se necessária a participação oportuna do investimento privado. Um investimento nacional ou estrangeiro que atua de ponte, para as transferências de recursos financeiros, materiais e tecnológico, indispensáveis ao sistema educacional. 
Krawczyk (2005) identifica duas formas em que vem ocorrendo a descentralização para o mercado. A primeira “[...] busca, prioritariamente, descentralizar para o mercado a responsabilidade de controle e regulação educacional, [e a segunda] pretende a descentralização da responsabilidade da oferta e universalização do serviço educativo." (op. cit., p. 811).

A dinâmica privatizadora da educação, assumida sob a mundialização do capital e do neoliberalismo, será analisada especificamente para o caso do México. As caraterísticas e funcionamento do sistema educacional mexicano nos ajudaram a compreender com mais clareza os objetivos econômicos e políticos da reforma educativa 2013 neste contexto econômico, análise que será realizada no capítulo 4 .

\subsection{O Tratado de Livre Comercio de América do Norte e a educação no México}

Com a aplicação dos PAE, nos anos oitenta do século passado, o México passa de uma política de proteção econômica e industrial à abertura total da economia, exposta totalmente à competitividade internacional, dinâmica que se intensifica em 1994 com a firma do Tratado de Livre Comercio de América do Norte (TLCAN). (FLORES, 2010).

A Organização Mundial do Comercio (OMC), consagra os princípios econômicos do neoliberalismo nas regras comerciais dos tratados de livre comercio, que abrem as fronteiras para o livre trânsito dos capitais e das mercadorias, e se liberalizam e privatizam as economias desde dentro, desde "[...] o coração da faculdade normativa dos governos." (GRIESHABER-OTTO; SINGER apud ABOITES AGUILAR, Hugo, 2007, p. 26). Nos anos de 1990, a educação entrou como tema de negociação do capital internacional, como bem altamente rentável, com grande diversificação de serviços e em constante expansão.

A mercantilização da educação, está destruindo seu caráter social e seu objetivo de formar ao homem integral. Esta privatização, está significando um desvio dos recursos públicos (como incentivo) para o setor privado que investe nos serviços educativos; a aplicação de objetivos e conteúdos educativos orientados ao mercado; práticas educativas gerenciais; métodos de gestão de resultados; flexibilização do trabalho educativo e condições precárias de emprego; combate contra os sindicatos. Isto é somente uma parte das consequências privatizadoras da educação que vários autores tem constatado (BALL, 2015; ROSARIO, 2010). 
A apertura comercial do México objetivada em 12 tratados de livre comercio com 44 países, tem transformado a economia e portanto os mercados laborais. $\mathrm{O}$ TLCAN é o primeiro e o mais importante acordo comercial (em questão do fluxo comercial) para o México. Neste tratado se estabelece a regulação da propriedade intelectual e da educação como parte dos serviços. Aboites (2007) relata como nos vários capítulos deste Tratado, se estabelecem: a) limites dos recursos públicos destinados à educação pública, b) restrição da matrícula pública, c) obrigação do setor público para não discriminar entre provedores, na compra de mercadorias ou serviços privados na educação, d) eliminação no possível dos efeitos "nocivos" da prática monopolista Estatal, assim como dos efeitos da política de competências em áreas reservadas exclusivamente a ele, e) inclusão de mecanismos de avaliação para regular a qualidade dos serviços e do capital humano ${ }^{38}$, f) oferecimento de um "trato nacional" a prestadores estrangeiros de serviços, g) facilitar a entrada temporal do capital humano e dos homens de negócio; entre outras medidas (ABOITES, 2007).

As reformas educativas impulsadas no México a partir dos organismos internacionais Banco Mundial, o FMI, UNESCO, a OCDE e a OMC obedecem conforme relatado, às necessidades de lucro e de expansão do capital. O discurso oficial do Banco Mundial e da OCDE centra-se na importância da educação, sobretudo no nível básico para eliminar os defasagens econômicos e educativos (demostrado nas avalições nacionais e internacionais) e em geral como mecanismo de combate à pobreza, daí a necessidade de expandir a educação (ALTMANN, 2002; CORDERO; SERRANO; PATIÑO, 2013; UNESCO, 2014), "Universalizar o acesso à educação e fomentar a equidade" UNESCO, 2014, p. 7).

Todas as "recomendações" destes organismos internacionais para a qualidade e equidade da educação no México, tem sido fielmente aplicadas. Neste sentido, desde 1992, com a promulgação da primeira reforma educativa "Acordo Nacional para a Modernização da Educação Básica" (ANMEB), que cria as bases para a nova Lei Geral de Educação (1993), até a reforma educativa 2013, implementaram-se duas grandes reformas constitucionais (2001 e 2008) e uma série de programas com mudanças administrativas, organizativas e financeiras da Secretaria de Educação Pública (SEP) e do sistema de educação básica e ensino médio superior (ORGANIZAÇÃO PARA A COOPERAÇÃO E DESENVOLVIMENTO ECONÔMICO,

38 Desde a visão neoliberal, o capital humano corporifica os conhecimentos acumulados nas pessoas (ABOITES, 2007). 
2009). A última reforma educativa aprovada em 2013 no México, elevou a categoria constitucional muitas das propostas e programas educativos de sexênios anteriores que não tinham conseguido executar-se totalmente.

As principais mudanças educacionais no México para o ensino básico, desde 1992 até 2016, segundo a literatura especializada caracterizam-se por: a) estarem focadas à reorganização do sistema educativo: descentralização dos serviços educativos para os estados e centralização da autoridade federal, que preserva o controle sobre os elementos decisivos do sistema educativo. Deixam-se para os governos estatais as responsabilidades administrativas; b) a reformulação dos conteúdos e materiais educativos. Homogeneização do currículo e dos livros de texto gratuitos; c) uma reforma docente, que estabelece a responsabilidade dos professores na qualidade educativa, estabelecendo a carreira magistral, a atualização docente, e a avaliação como indicador para a toma de decisões na estabilidade laboral, salarial, nos incentivos e estímulos a receber; d) a avaliação permanente do sistema educativo; e) a reforma da escola, que visa a autonomia financeira e administrativa das escolas. (ORGANIZAÇÃO PARA A COOPERAÇÃO E DESENVOLVIMENTO ECONÔMICO, 2009).

A implantação da "reforma educativa 2013", foi possível, graças ao Pacto por México, acordo político nacional assinado o 2 de dezembro de 2012 entre o Presidente da República e os presidentes dos três principais partidos políticos: Partido Revolucionário Institucional (PRI), Partido Ação Nacional (PAN), e Partido da Revolução Democrática (PRD).

A continuação, apresentaremos as principais contribuições da teoria históricocultural respeito aos conceitos de homem, trabalho e educação; que nos ajudem a compreender o importante papel da educação para a formação do homem como sujeito.

Toda política educacional é desenhada, segundo o enfoque teórico desses conceitos. Os objetivos educacionais, são logo congruentes com os objetivos de homem que se quer, com a sociedade que se busca construir.

\subsection{A educação em uma perspectiva histórico-dialética}

$\mathrm{Na}$ interação com a natureza e na produção material para satisfazer suas necessidades, o homem tem-se constituído a si mesmo (LEONTIEV, 1978). Os 
progressos culturais alcançados no decorrer da história, são transmitidos de geração em geração, mediante a educação. Este processo cria aos novos homens para sua inserção na atividade e estrutura social.

Segundo a perspectiva histórico-cultural (LEONTIEV, 1978, 1984; VIGOTSKI, 2015), a educação é entendida como a apropriação da cultura pelo homem, apropriação da experiência social, significações sociais e de tudo aquilo produzido pelos homens em sociedade, evitando desta forma, começar de zero, reinventar, produzir e redescobrir cada vez. Reiniciando e retrocedendo não haveria evolução nem história humana.

A educação, por conseguinte, é um processo de ensino-aprendizado que permite a continuidade no progresso social. E na medida que as sociedades avançam em conhecimento, o processo de ensino vai tornando-se cada vez mais complexo. Citando a Leontiev (1978), temos que:

\begin{abstract}
Quanto mais progride a humanidade, mais rica é a prática sócio-histórica acumulada por ela, mais cresce o papel específico da educação e mais complexa é a sua tarefa. Razão por que toda a etapa nova no desenvolvimento da humanidade, bem como no dos diferentes povos, apela forçosamente para uma nova etapa no desenvolvimento da educação: o tempo que a sociedade consagra à educação das gerações aumenta; criam-se estabelecimentos de ensino, a instrução toma formas especializadas, diferencia-se o trabalho do educador do professor; os programas de estudo enriquecem-se, os métodos pedagógicos aperfeiçoamse, desenvolve-se a ciência pedagógica. Esta relação entre o progresso histórico e o progresso da educação é tão estreita que se pode sem risco de errar julgar o nível geral do desenvolvimento histórico da sociedade pelo nível de desenvolvimento do seu sistema educativo e inversamente. (LEONTIEV, 1978, p. 273, destaque nosso).
\end{abstract}

Porém, como menciona o próprio Leontiev (1978), a possibilidade de apropriação dos frutos do desenvolvimento cultural está em função do sistema econômico, que permite ou não a socialização da produção material e intelectual. No capitalismo, este fato cria desigualdades, divisão de classes sociais, e a alienação econômica e cultural (educacional). (LEONTIEV, Ibid.)

Portanto, como aponta Leontiev (Ibid.), uma sociedade será mais desenvolvida econômica e socialmente, sempre e quando sua política educacional tenha como objetivo, brindar a todos os homens - isto é, sem distinção de classes -, o saber adquirido historicamente, para sua própria evolução e da sociedade.

Isto significa que em uma sociedade justa e igualitária, a educação vai estar sempre dirigida à formação integral do homem. 
$\mathrm{Na}$ perspectiva histórico-cultural, o trabalho e a educação, constituem ao homem, isto é, são mediações que permitem a apropriação cultural. Esta afirmação é de grande relevância, e aporta luz para esta pesquisa, em quanto, considera ao trabalho só como mediação para a aprendizagem, para formar ao homem integral: chame-se estudante, professor ou trabalhador; porque a educação e formação se dá ao longo da vida toda. No capitalismo, o trabalho tem uma conotação negativa, ela é a finalidade, não a mediação, educa-se para o trabalho, um trabalho penoso, rotineiro, mecanicista, competitivo e alienante. Utiliza-se o trabalho para explorar e alienar ao homem, em vez de constituí-lo.

Pensando no sentido de uma verdadeira reforma educativa, os objetivos das atividades pedagógicas (trabalho pedagógico): os métodos pedagógicos, os currículos, a formação de professores, devem estar focados à formação do sujeito. $O$ que significa um conhecimento pleno do seu objeto de estudo e de sua participação transformadora nele. É, portanto, indispensável que neste processo, cada um deles se aproprie do objeto de seu trabalho (MORETTI, 2007), para que todo conhecimento Ihes permita adotar em todo momento, uma atitude ativa, criativa, formativa e de contribuição para eles e a sociedade.

Mas quem que é o homem, e como que é o seu processo de aprendizado?

Conforme a teoria marxista (VIGOTSKI, 1995a; 1995b; 2000; 2015; LEONTIEV, 1978; PINO, 2000) o homem é um ser social, resultado da fusão entre o biológico (o organismo, "forma primitiva") com o social (o meio, "formas culturais") ${ }^{39}$. Segundo Vigotski (1995a; 1995b) a humanização supõe um longo e difícil processo histórico de evolução, involução e finalmente uma revolução de fatores internos e sociais, em que se superam todas as dificuldades para sua supervivência e adaptação a esse meio social. Vigotski nos explica este fenômeno ativo na evolução do ser humano, a partir da análise no desenvolvimento da criança:

[...] trata-se de um complexo processo dialético que se distingue por uma complicada periodicidade, a desproporção no desenvolvimento das diversas funções, a metamorfose ou transformação qualitativa de umas formas em outras, um entrelaçamento complexo de processos evolutivos e involutivos, 0 complexo cruzamento de fatores internos e externos, um complexo processo de superação de dificuldades e de adaptação. (VIGOTSKI, 1995b, p. 141, tradução nossa) $)^{40}$.

\footnotetext{
39 Ver Vigotski (1995a; 1995b) e Leontiev (1975).

40 se trata de un complejo proceso dialéctico que se distingue por una complicada periodicidad, la desproporción en el desarrollo de las diversas funciones, las metamorfosis o transformación cualitativa
} 
O desenvolvimento cultural não pode ser apenas considerado como uma relação "mecanicista" que vai do externo (o cultural) ao interno (o psiquismo do homem), precisa ser analisado também como um processo dialético, em que a compreensão (e não só assimilação) dos significados sociais pelo homem são condição fundamental para a criação de novas formas materiais, intelectuais e espirituais (RUBINSTEIN, 1973).

As faculdades das pessoas se formam não apenas no processo de assimilação dos produtos criados pelo homem no decorrer do desenvolvimento histórico, mas também no processo de sua criação, já que o processo de criação do mundo material pelo homem é ao mesmo tempo o desenvolvimento de sua própria natureza. (RUBINSTEIN, 1973, p. 239).

Si bem é verdade que o homem tem um primeiro nascimento biológico e posteriormente assiste a um segundo nascimento cultural (PINO, 2005), e que seu desenvolvimento está agora "[...] submetido não às leis biológicas, mas a [sic] leis sócio-históricas." (LEONTIEV, 1978, p. 262); o desenvolvimento das faculdades psicológicas superiores dá-se na inter-relação e complementação entre o mundo natural e a atividade prática dos homens (que é o que diferencia ao homem do animal). (RUBINSTEIN, 1973). Podemos dizer que, a natureza psíquica do homem se identifica por ter um caráter histórico (como ciência única) e cultural, em que ficam unidos essa "dupla natureza". (RUBINSTEIN, 1973).

Quer dizer que, no processo de ensino-aprendizado, será necessário utilizar mediações determinadas que permitam a plena formação do sujeito, para que sua educação se traduza na apropriação do conhecimento, e não de uma assimilação dos conceitos e operações, que significam a simples transposição do externo para dentro, "a interiorização do externo" (RUBINSTEIN, Ibid.). Se precisa uma verdadeira compreensão e conhecimento do mundo, que permita analisar, questionar, para aportar, produzir, criar soluções, etc. Precisa-se de uma educação integral que permita desenvolver em sua máxima e maravilhosa potência, as faculdades psicológicas superiores dos homens.

de unas formas en otras, un entrelazamiento complejo de procesos evolutivos e involutivos, el complejo cruce de factores internos y externos, un complejo proceso de superación de dificultades y de adaptación. 
Quando o homem produz, ele se transforma física e psicologicamente; desenvolve ainda mais suas capacidades, que são suas faculdades psicológicas (RUBINSTEIN, Ibid.), e nessa produção ele utiliza o corpo todo. É através dos sentidos que captamos o mundo (LEONTIEV, 1984) e que contribuímos ao mundo; portanto, uma educação humanizadora, precisa das disciplinas que permitam o movimento do corpo todo, despertar as diferentes partes do corpo, dos sentidos, desenvolver as faculdades intelectuais, criar a confiança, estimular a criatividade, ensinar o amor, a solidariedade, o trabalho em equipe, etc.

Uma educação humanizadora precisa, de materiais, equipes, enfim, de todo tipo de mediações que possibilitem conseguir o objetivo único de formar ao homem ciente, libre, solidário e revolucionário.

As mediações sociais segundo Vigotski, são um produto social que possibilitam a interação social entre os homens e a possibilidade de aprendizagem. Assim como os instrumentos de trabalho constituem a ponte entre o homem e a natureza, estes instrumentos e signos (ou símbolos) sociais contêm todos os significados sociais produzidos pelos homens, e são por conseguinte, os responsáveis da transformação, "internalização" das relações sociais em funções psíquicas (VIGOTSKI, 1995a; 1995b).

Para Vigotski (1995b) os signos são a condição para relacionar-se socialmente, com os outros, e são a "[...] base de toda a história humana [...]" (PINO, 2000, p. 58), a partir deles se desenvolve e evoluciona a humanidade. Aparece o "mundo simbólico" e da "significação" e é a compreensão do significado das coisas que lhe dá um carácter social ao ser humano. Entre os signos temos a linguagem, que é fundamental para a reflexão e o pensamento verbal.

O homem nasce com certas funções psicológicas elementares (orgânicas), como as ações reflexas, as reações automatizadas, as associações simples, e outros processos elementares. Estas funções são a base e o complemento para que possam surgir novas formas de funções superiores (VIGOTSKI, 1995b).

As funções psicológicas superiores, como: a percepção, a atenção, a memória, o pensamento, a consciência, a intenção, o planejamento, todas as ações voluntárias; se desenvolvem com a interação social dos homens, isto é, com as práticas sociais. Este é um processo que se constrói internamente, na consciência do homem. A partir da mediação de signos e instrumentos sociais, as relações sociais são internalizadas e são transformadas em processos psicológicos, em funções sociais da personalidade 
do indivíduo, que possibilitam sua constituição como ser social. (VIGOTSKI, 1995b). Citamos textualmente a Vigotski (Ibid., p. 151): "Modificando a conhecida tese de Marx, poderíamos dizer que a natureza psíquica do homem é um conjunto de relações sociais trasladadas ao interior e convertidas em funções da personalidade e em formas de sua estrutura."

Desta forma, podemos compreender o como a estrutura econômica, o modo de produção, determinam as relações e práticas sociais e como estas a sua vez, são internalizadas nos homens (MARX, 1977, VIGOTSKI, 1995a; 1995b). São estes significados sociais, as condições materiais de vida, que definiram a consciência e personalidade nos homens (MARX, 1977); um fato de grande importância para compreender os processos de desenvolvimento das sociedades, e para pensar na educação pública, como o espaço único para criar novas mediações (planos de estudo, material pedagógico) e relações sociais democráticas no trabalho pedagógico; que se traduzam na possibilidade de formar homens que tenham o conhecimento científico, a consciência para lutar contra a exploração, por uma sociedade mais justa.

No próximo capítulo, apresentaremos as caraterísticas do sistema educacional no México, os objetivos e a orientação que tem adotado desde os anos de 1990, assim como a análise das principais reformas na educação em 2013. Esta análise, nos permitirá entender, o como estas modificações constitucionais fazem parte de uma lógica capitalista que está definindo o caráter do ser humano, mediante a prática educativa. 


\section{NATUREZA ECONÔMICA E POLÍTICA DA REFORMA EDUCATIVA 2013 NO MÉXICO E O SISTEMA EDUCACIONAL MEXICANO}

A educação está presente na formação de todo homem e sociedade de forma "assistemática", isto é, "[...] indiferenciada; ou seja: não se distinguem ensino, escola, graus, ramos, padrões, métodos, etc." (SAVIANI, 2000, p.88-89). A educação como "atividade sistemática" é assumida pelo Estado, tendo a escola como a instituição social, o lugar em que se realiza esta função.

$\mathrm{Na}$ escola realiza-se o processo educacional sistemático, o processo de ensinoaprendizagem necessário para formar e incorporar ao novo homem na sociedade. Por tanto, esse processo educativo terá que levar em conta as caraterísticas físicas, biológicas, mentais, psíquicas, sociológicas do educando, do homem como ser completo e único, como unidade e como ser diferenciado à vez; e em base a estas especificidades, elaborar um método pedagógico. Um método baseado numa teoria, que brinde as ferramentas metodológicas para poder atingir seu objetivo, a formação do homem integral.

Teoria e método constroem o sistema educacional, que orientará o rumo da educação. Toda teoria, e portanto todo método pedagógico, deverão construir-se tomando em conta a problemática educativa do país, o seu contexto educativo e socioeconômico.

Neste capítulo, procuramos conhecer a organização e desenvolvimento do sistema educacional e a teoria que tem orientado o processo educativo.

Analisaremos as principais leis da reforma educativa 2013 e os princípios econômicos e políticos que estão presentes nela, definindo o sistema educativo todo.

\subsection{Breve histórico do Sistema Educacional Mexicano}

Tal como já reiteramos, a organização da economia e da sociedade em seu conjunto são congruentes com o modo de produção ao qual pertencem. Nesta visão de totalidade, as características atuais do Sistema Educacional Mexicano (SEM) ${ }^{41}$ devem ser analisadas no seu contexto histórico, e relacionadas aos principais fatores

\footnotetext{
${ }^{41}$ No México se conhece como o Sistema Educacional Nacional (SEN), mas neste trabalho, vamos nos referir a ele como Sistema Educacional Mexicano (SEM).
} 
econômicos e políticos nacionais e internacionais que tem um estreito vínculo com a educação no México.

Antes que nada, é preciso saber o que é um Sistema Educacional. Segundo Saviani (2000) uma vez que o homem tem como objetivo educar intencionalmente ás novas gerações para a apropriação do produzido historicamente pelo homem (ver também LEONTIEV, 1978), aparece a educação sistematizada, que representa um "ato refletido e intencional", em direção a um objetivo, a constituição do ser humano, do ser cultural. A educação sistematizada é portanto uma atividade sistematizadora, "uma práxis intencional" em que o homem faz consciência da importância da sua ação educativa, reflete sobre ela, identifica os problemas, brinda soluções, que se transformam em ações para a atingir seu objetivo principal.

Para Saviani (Ibid), o ato de sistematizar implica não só um ato intencional, mas também a organização, união de elementos relacionados e coerentes entre si. "Sistematizar é, pois, dar, intencionalmente, unidade à multiplicidade. E o resultado obtido, eis o que se chama de sistema." (SAVIANI, op. cit., p. 77).

O sistema é logo o resultado de uma práxis intencional, que se caracteriza por reunir uma série de "[...] práxis intencionais individuais [que] conduzem a um produto comum inintencional [...]" (Ibid., p. 85).

Desta forma, o sistema educacional, como produto social, de interesse comum, nacional e não individual, organiza e unifica os elementos econômicos, políticos, jurídicos e sociais de uma nação, gera e organiza as instituições para a ação educativa sistematizada, em função das necessidades e da realidade sócio-educativa existente.

Para Saviani (2000), a teoria educacional representa essa guia sob a qual se expressam os objetivos, concepções e organização da educação a nível nacional, para chegar a esse "produto comum intencional" acima citado.

Continuando com Saviani (2000, p. 87), um sistema educacional apresentaria as seguintes caraterísticas:
a) Consciência dos problemas da situação;
b) Conhecimento da realidade (as estruturas);
c) Formulação de uma pedagogia.

Explicitado o conceito de sistema educacional em geral e tendo em conta as características apresentadas, passaremos a entender as especificidades deste conceito para o caso mexicano. 
O Sistema Educacional Mexicano (SEM) tem suas origens no ideário da revolução mexicana, a Constituição de 1917, que foi brindar educação ${ }^{42}$ pública e gratuita ao povo, mas sobretudo aos indígenas e camponeses com quem o país está em dívida; a educação é vista como uma forma de inseri-los na sociedade, melhorar suas condições de vida e fazê-los cidadãos partícipes do desenvolvimento econômico nacional (ARNAUT, 1998; ORNELAS, 2011; KRAWCZYK, 2008).

Com esta finalidade é criada a Secretaria de Educação Pública (SEP) em 1921, que desde seus inícios estabelece escolas ao longo do país, absorbendo da mesma forma as escolas municipais para centralizar a educação, e guiá-la sob uma orientação nacionalista e laica fundada nos princípios arraigados da revolução mexicana (ARNAUT, 1998; KRAWCZYK, 2008).

Se é certo que a ênfase esteve centrada na cobertura da educação sobretudo o ensino fundamental obrigatório - "[...] um dos compromissos históricos e constitucionais do Estado mexicano." (ARNAUT, 1998, p. 20, tradução nossa) ${ }^{43}$ - o crescimento educativo desde então, se sobrepõe à qualidade educativa. Umas das razões: a) a rigidez do sistema educacional originada pela centralização; b) a isenção da participação dos estados, municípios e da sociedade em geral na discussão da política educacional e, c) a magnitude e complexidade do processo educativo que dificultou a possibilidade de reflexão dos problemas para sua transformação e desenvolvimento (ARNAUT, 1998).

Porém, os progressos conseguidos até 1958 no sistema educacional, são de grande importância para a integração do México como nação, assim como para o povo mexicano em seu conjunto ${ }^{44}$.

A partir dessa data, os problemas educativos existentes (administrativos, técnicos e pedagógicos) exigem uma reestruturação imperativa da SEP, que não vai conseguir efetuar-se. A forte centralização do sistema educacional ${ }^{45}$ desses anos lhe permitiu ganhar autonomia mesmo sobre o próprio governo federal, fortalecendo aos principais interlocutores do sistema: a SEP e o Sistema Nacional dos Trabalhadores

\footnotetext{
42 Respeito ao ensino fundamental, se expressa já sua obrigatoriedade e universalidade (ORNELAS, 2011).

43 [...] uno de los compromisos históricos y constitucionales del Estado mexicano.

${ }^{44}$ Segundo Hernández (2015, p. 19), após o período revolucionário a importante criação de escolas ao longo do país, consegue reduzir a taxa de analfabetismo aproximadamente num 70 por cento.

$45 \mathrm{Em}$ julho de 1944 se firma um pacto entre o governo federal e os trabalhadores da educação, para criar um sindicato único reconhecido pela federação. Com a finalidade de reunir a todos os pequenos sindicatos de professores e outros trabalhadores da SEP, para assim legitimar tanto as relações de dominação do Estado, como as políticas educacionais. (ORNELAS, 2011).
} 
da Educação (SNTE) principalmente. Em palavras de Arnaut (1998): "As autoridades educativas tinham perdido o controle sobre os professores [...] a SEP afrontava os problemas derivados do seu crescimento e do fortalecimento do poderio sindical [...]". (Ibid., p. 22, tradução nossa) ${ }^{46}$. Novas estruturas de poder na educação se conformaram, decidindo o caminho educacional a seguir.

A necessidade de reformar o SEM para atender a qualidade educacional e para retomar a governabilidade da SEP e da educação nacional, orientou à política educacional para processos paulatinos de descentralização a partir de 1970. No sexênio presidencial de 1970-1976, criam-se oito Unidades de Serviço regionais que atendiam questões administrativas e laborais dos professores. No seguinte período (1976-1982) o governo federal cria as primeiras delegações da Secretaria de Educação em cada estado da República ${ }^{47}$, e em $1982^{48}$ o país é protagonista do começo de uma radical descentralização da educação que vai continuar até nossos dias. A SEP delega aos estados da república os principais serviços educativos e laborais particularmente $o$ ensino fundamental $e$ as escolas normais. Esta transferência de recursos continuará e se consolidará principalmente no período presidencial de 1988-1994 com a firma do Acordo Nacional para a Modernização da Educação (ANMEB) em 1992 e a promulgação da Lei Geral de Educação (LGE) em 1993, base jurídica desta reforma (ARNAUT, 1998; MÉXICO, 1992; ORGANIZAÇÃO PARA A COOPERAÇÃO E DESENVOLVIMENTO ECONÔMICO, 2009).

Este último período conhecido como o "federalismo educativo49" ou "novo federalismo", é uma "inversão do centralismo" (KRAWCZYK, 2008), uma transferência de todos os serviços educativos federais para os estados, "[...] ao tempo que o governo federal conserva e fortalece suas faculdades normativas sobre 0 conjunto do sistema educacional nacional" (ARNAUT, 1998, p. 17) ${ }^{50}$, política que permite ao sistema educacional conservar seu caráter nacional e à autoridade federal preservar o controle tanto dos professores como do sistema todo.

\footnotetext{
${ }^{46}$ Las autoridades educativas habían perdido el control sobre los maestros [...] la SEP afrontaba los problemas derivados de su crecimiento y del fortalecimiento del poderío sindical.

47 Os Estados Unidos Mexicanos, é uma República federal integrada por 31 estados e um Distrito Federal.

48 O país atravessava uma grave crise econômica, que impediu avançar no processo de descentralização educativa (ORNELAS, 2011).

${ }^{49}$ Assim expressado no Diário Oficial da Federação do dia 19 de maio de 1992 (MÉXICO, 1992, p.7).

$50[\ldots]$ al mismo tiempo que el gobierno federal conserva y refuerza sus facultades normativas sobre el conjunto del sistema educativo nacional.
} 
Como vimos no subitem 2.1, a crise do capitalismo dos anos setenta veio a impulsionar um novo modelo econômico e uma diminuição do Estado na economia. Ante a crise fiscal das economias latino-americanas e o rápido processo de internacionalização e globalização das economias, organismos internacionais tais como o Banco Mundial e o Fundo Monetário Internacional (FMI), brindaram empréstimos às economias e impuseram os Programas de Ajuste Estrutural (PAE) como medidas para a estabilização macroeconômica, a reestruturação econômica e a inserção internacional com competitividade das economias. Todas elas foram diretrizes econômicas e sociais orientadas à privatização, à descentralização e ao desmantelamento dos bens e serviços públicos que favoreceram a liberdade de um mercado "auto-regulador" (ROSARIO, 2010).

A partir dos anos noventa, grandes organismos internacionais (Banco Mundial, BID, UNESCO, OCDE, principalmente) apelam à universalização e qualidade da educação básica como um dos fatores decisivos para a coesão e equidade social, para a produtividade escolar e econômica que incidam no desenvolvimento e competividade das nações.

A aplicação da Gestão educativa no México a partir dos anos noventa, forma parte dessa lógica economicista e neoliberal da educação. Descentralização da educação junto com as práticas de gestão educativa, colocaram o foco na qualidade e na avaliação da aprendizagem, transformando e redefinindo o Sistema Educacional Mexicano (SEM).

Nesse sentido, o ANMEB firmado em 1992, descentralizou para os estados a educação básica e normal, porém o poder real permaneceu na SEP (governo federal) e o SNTE (ORGANIZAÇÃO PARA A COOPERAÇÃO E DESENVOLVIMENTO ECONÔMICO, 2009). O executivo federal fica com as principais decisões sobre o SEM, respeito à sua normatividade; ao conteúdo dos planos e programas educacionais; planos de carreira e remuneração do magistério, assim como no gasto público educacional. Os governos estatais recebem a responsabilidade operativoadministrativa e o SNTE conserva sua representatividade nacional para pactuar com a SEP as questões salariais e laborais do magistério (ORGANIZAÇÃO PARA A COOPERAÇÃO E DESENVOLVIMENTO ECONÔMICO, 2014).

Para garantir um processo de federalização da educação bem-sucedido o Acordo estabeleceu quatro estratégias principais: a) o aumento do financiamento federal e estadual na educação; b) a "reorganização" do SEM; c) a "reformulação", 
atualização dos programas e materiais educativos ${ }^{51}$; d) a "reavaliação da função do magistério" e a reforma docente. (MÉXICO, 1992; ORGANIZAÇÃO PARA A COOPERAÇÃO E DESENVOLVIMENTO ECONÔMICO, 2009).

A reorganização do SEM, não é só uma questão de transferência dos serviços educativos, ela integra também as responsabilidades políticas, laborais, administrativas e eventualmente econômicas em cada estado (ARNAUT, 1998). Nesse federalismo educativo se identificam as responsabilidades normativa, financeira, administrativa, técnica, e aquelas concernentes aos recursos físicos (infraestrutura e materiais escolares) para cada âmbito de governo (federal e estadual).

Esta reestruturação do SEM significou ademais, a incorporação da comunidade escolar (autoridades escolares, professores e pais), dos empresários com um papel protagonista, e o retorno da Igreja Católica nos assuntos educacionais (KRAWCZYK, 2008).

Diante a liberalização econômica do México, o governo federal decide vincular ao empresariado com a educação como uma forma de modernizar e atualizar os planos e programas de ensino acordes com esse novo cenário. Segundo análise de Krawczyk (2008), a ingerência desse "empresariado moderno" mexicano na educação, é no sentido de identificar as novas necessidades econômicas, sobretudo do mercado internacional, e preparar às novas gerações para o trabalho, um trabalho produtivo que impulsione a competitividade das empresas e da nação.

A respeito da Igreja Católica, segundo relato de Krawczyk (2008, p. 103) existe evidencia da pressão que ela exerceu no governo para aumentar o apoio público à educação privada e/ou religiosa, assim como para participar nos "conteúdos curriculares escolares" com seu moralismo conservador ${ }^{52}$.

A reavaliação do magistério no ANMEB significa considerá-lo como "O protagonista da transformação educativa do México [...]”. (MÉXICO, 1992, p.12), cujo protagonismo implica nos fatos responsabilizá-lo pela baixa qualidade na educação

\footnotetext{
51 Implicou uma reorganização curricular para o ensino fundamental e médio, com especial ênfase na leitura, escritura e matemáticas; assim como uma reforma dos livros de texto, sob a responsabilidade do governo federal (MÉXICO, 1992).

52 Para entender a coalizão entre Estado e religião e seu impacto na educação, recomenda-se ler Apple (2003). O autor faz uma análise interessante sobre os principais grupos que conformam a aliança neoconservadora nos Estados Unidos, e que controlam a política nacional. Analisa como desde os anos noventa, principalmente, esta aliança tem decidido os rumos educacionais com graves consequências. Este livro nos mostra por tanto o que vem acontecendo também nas economias latinoamericanas, importadoras desse modelo neoliberal-conservador na educação.
} 
nacional, à vez que ele é designado o encarregado de conseguir os objetivos de qualidade na aprendizagem plasmados no Acordo, com margens baixas ou nulas de autonomia. Com essa finalidade é reformada a educação normal. Se estabelecem programas de atualização, um Programa de Carreira do Magistério ${ }^{53}$ (em 1993) e uma série de avaliações nacionais tanto para o magistério como para os alunos do ensino básico.

As estruturas de poder do SNTE foram também transferidas às secretarias e instituições educacionais estatais, e estas não permitiram que o ANMEB conseguisse sua plena descentralização (ORGANIZAÇÃO PARA A COOPERAÇÃO E DESENVOLVIMENTO ECONÔMICO, 2009; KRAWCYZK, 2008). A SEP e o SNTE continuam mantendo o controle e "[...] liderança na gestão do sistema educacional no país, nos estados e nas escolas." (KRAWCYZK, 2008, p. 105).

Para garantir a continuidade do federalismo e a aplicação do ANMEB, em 1993 se reforma 0 artigo $3^{\circ}$ Constitucional e é decretada a Lei Geral de Educação (LGE) que substituirá à Lei Federal de Educação (LFE) promulgada em 1973 (ARNAUT, 1998). Se substitui o termo Federal por Geral porque no marco do federalismo ela contém disposições legais que se aplicam aos três níveis de governo: federal, estadual e municipal. Além de ser a base jurídica e política do artigo $3^{\circ}$ Constitucional, para regulamentar a educação a nível nacional (BARBA, 1994).

A LGE plasma os objetivos principais em matéria de equidade e de qualidade para a educação básica em que se inclui à educação primaria (6 anos de duração) e o ensino secundário (3 anos de duração); e se constituem os programas compensatórios para garantir essa equidade social e educativa (ORGANIZAÇÃO PARA A COOPERAÇÃO E DESENVOLVIMENTO ECONÔMICO, 2009). No artigo 29 da LGE, se estabelece também a responsabilidade federal pela avaliação nacional da educação (BARBA, 1994).

Por primeira vez, na LGE se reconhece oficialmente a titularidade de um sindicato, o SNTE como interlocutor do magistério ante a SEP (ARNAUT, 1998). Assim mesmo, a LGE legaliza as funções do Estado na direção, condução, financiamento e intervenção no SEM, ao tempo que se adicionam novas importantes

${ }^{53}$ Este é um programa nacional de incentivos para o magistério, no qual se estabelece um sistema de bônus salariais segundo o seu desempenho. (CORDERO; LUNA; PATIÑO; 2013). 
funções do governo federal ${ }^{54}$. Retomando a Ornelas citado pela Organização para a Cooperação e Desenvolvimento Econômico (2014, p. 5, tradução nossa), ressaltamos - seguinte: "Em outras palavras, se centraliza o poder e se descentraliza a administração. Essa é a essência do modelo formal da descentralização educativa do México." 55

Segundo Krawczyk (2008), os objetivos de equidade no financiamento da educação com o objetivo de reduzir as desigualdades regionais, não deu fruto e exacerbou ainda mais a diferenciação social. As políticas compensatórias, destinadas às zonas mais marginalizadas, em quanto ao gasto público foram insuficientes, "[...] o que impunha às autoridades escolares a busca de formas alternativas de financiamento, sendo a mais procurada a colaboração dos pais." (Ibid., p. 119). Equidade e gratuidade, elementos centrais no artigo $3^{\circ}$ Constitucional e na LGE, são portanto questionados (lbid.).

Já no ANMEB se perfila a reforma da escola, com a autonomia escolar, indispensável na modernização neoliberal da educação. Nela se estabelece a participação da comunidade escolar e da sociedade em seu conjunto nas decisões administrativas e financeiras das escolas (KRAWCZYK, 2008; ORGANIZAÇÃO PARA A COOPERAÇÃO E DESENVOLVIMENTO ECONÔMICO, 2009), mas com uma contradição porque a LGE não possibilita a autonomia administrativa escolar desde os estados (ORGANIZAÇÃO PARA A COOPERAÇÃO E DESENVOLVIMENTO ECONÔMICO, 2009).

Em 1994 começam mais seriamente as discussões sobre a centralidade da escola, entre a SEP e os estados. Entre 1996 e 1998 a SEP impulsionada pela "Comissão Internacional sobre a Educação para o Século XXI", implementa o programa: "Projeto de Gestão da Escola Primária" (PGEP), (KRAWCZYK, 2008; ORGANIZAÇÃO PARA A COOPERAÇÃO E DESENVOLVIMENTO ECONÔMICO, 2009), projeto que tinha como objetivo, propiciar uma melhor comunicação e cooperação no trabalho escolar entre professores e diretores (KRAWCZYK, 2008).

\footnotetext{
54 Mais detalhes a este respeito podem ser encontrados no documento da Organização para a Cooperação e Desenvolvimento Econômico (2009).

${ }^{55}$ En otras palabras, se centraliza el poder y se descentraliza la administración. Esa es la esencia del modelo formal de la descentralización educativa de México.
} 
Fiel a descentralização e a reforma da escola, proclamada pela UNESCO, no período 2000-2006 foi criado o Programa Escolas de Qualidade (PEC) ${ }^{56}$, com os objetivos institucionais de fomentar a democracia e de aumentar a qualidade da educação básica. Este Programa que substitui o PGEP, propõe uma nova gestão para as escolas e o sistema educacional, no sentido de estabelecer uma relação de trabalho desde as escolas para o SEM, tentando eliminar o centralismo nas decisões administrativas e financeiras do ANMEB (BARUCH, 2007; ORGANIZAÇÃO PARA A COOPERAÇÃO E DESENVOLVIMENTO ECONÔMICO, 2009). Porém, segundo Krawczyk (2008, p.117), o PEC -que é implementado em 2001, sem tomar em conta os resultados do PGEP- "[...] incorporou a visão do empresariado e a lógica competitiva do mercado nas mudanças da gestão escolar."

A principal proposta do PEC centra-se em melhorar a qualidade educacional a partir do fortalecimento da capacidade de gestão das escolas de educação básica, refletida na capacidade para elaborar projetos de desenvolvimento escolar, que visam a melhoras na sua organização, gestão, financiamento, qualidade do ensino e avaliação. É um Programa voluntario para as escolas da periferia ${ }^{57}$ em que a comunidade escolar participa, a partir de seus conselhos escolares, identificando as necessidades, as metas educacionais e institucionais, e elabora a organização e gestão para sua execução (BARUCH, 2007; KRAWCZYK, 2008; LOYO, 2006).

O PEC supõe que uma escola de qualidade é aquela em que participa a comunidade educacional. A gestão educacional estratégica, favoreceria a prática pedagógica e a participação dessa comunidade escolar (BARUCH, 2007; KRAWCZYK, 2008). Porém, em base a um estúdio feito por Krawczyk (2008), se constata que a participação dos pais limitou-se a reuniões escolares e às contribuições econômicas para a "[...] manutenção da escola e a compra de equipamentos [...]." (lbid., p.119).

Embora o Programa fosse voluntario, muitas escolas foram implementando-o porque representou a possibilidade e ao mesmo tempo condição para a obtenção de recursos financeiros adicionais ${ }^{58}$. Recursos que se obtinham apresentando projetos

\footnotetext{
56 Pelas siglas em espanhol: Escuelas de Calidad (PEC). Este Programa começa a operar em abril de 2001, e forma parte das ações da "Política de transformação da gestão escolar" do Programa Nacional de Educação 2001-2006 (PRONAE), (MÉXICO, 2001, p.139).

57 Escuelas urbano marginales.

58 Segundo Loyo (2006) e Alcántara (2011), o financiamento do PEC assim como de outros programas educativos e sociais foi insuficiente ao longo de esse sexênio.
} 
que plasmaram a autonomia escolar, pretendida pelo governo federal. Esta busca pelos recursos incentivou, segundo análise de Krawczyk (2008), uma competição entre as escolas, isto é se introduziu a lógica competitiva do mercado nas escolas.

A busca por este orçamento federal e pelo prestigio de pertencer a uma escola de qualidade (LOYO, 2006), centrou os esforços dos centros escolares na elaboração de projetos administrativos em detrimento do projeto pedagógico. A nível federal, a função da SEP focara-se também na capacitação de diretores para a elaboração dos projetos escolares e para a autogestão administrativa e financeira ${ }^{59 ~ "[\ldots] ~ e m ~ v e z ~ d e ~}$ promover reflexões sistemáticas sobre o fazer educativo [...]." (KRAWCZYK, 2008, p. 118).

Uma forma de garantir a eficiência do gasto público dedicado à educação, para a equidade e qualidade -principais aspectos contidos no Programa Nacional de Educação 2001-2006 (PRONAE)- será a criação do Instituto Nacional para a Avaliação da Educação (INEE) ${ }^{60}$ em 2002 (ALCÁNTARA, 2011; LOYO, 2006; MÉXICO, 2001, p. 100). Este é um objetivo de grande relevância no PRONAE 20012006.

Este Instituto surge de um decreto presidencial, como um organismo público, de caráter técnico e descentralizado da SEP, com a função de avaliar o conjunto do sistema educacional, sobretudo na educação básica (educação infantil61, ensino fundamental, e ensino médio) e média superior (ALCÁNTARA, 2011). As avaliações nacionais do Instituto são independentes daquelas que a SEP tem a seu cargo, como; a avaliação do PEC; as Provas de Aproveitamento Escolar da Carreira do Magistério; as Olimpíadas do Conhecimento, e as Avaliações Nacionais do Êxito Acadêmico em Centros Escolares (Enlace) ${ }^{62}$, desde 2006. Respeito a este último, Cordero, Luna e Patiño (2013, p. 3) mencionam que, "[...] Enlace tinha um enfoque formativo de

\footnotetext{
${ }^{59}$ Cada escola deve conhecer as Regras de Operação vigentes para submeter o projeto escolar, deve ter capacidade de autogestão e prestar contas como ajuda do Manual para o Exercício e Comprovação dos Recursos do Programa Escola de Qualidade, entre outros documentos importantes do PEC (BARUCH, 2007; ORGANIZAÇÃO PARA A COOPERAÇÃO E DESENVOLVIMENTO ECONÔMICO, 2009).

60 Pelas siglas em espanhol do: Instituto Nacional para la Evaluación de la Educación (INEE).

61 Uma das principais reformas jurídicas deste sexênio, foi a incorporação em 2004, da educação infantil (tem duração de três anos) ao ciclo de educação básica obrigatória (LOYO, 2006).

62 Pelas siglas em espanhol: Evaluación Nacional del Logro Académico en Centros Escolares (Enlace). A partir de 2006, este exame anual se introduz a nível nacional para medir o desempenho nas disciplinas de espanhol e matemáticas (basicamente) dos estudantes dos três últimos anos do ensino fundamental (ORGANIZAÇÃO PARA A COOPERAÇÃO E DESENVOLVIMENTO ECONÔMICO, 2014).
} 
retroalimentação para professores, alunos e pais de família. [...] O seu enfoque mudou e seu uso está agora relacionado com a concessão de estímulos econômicos a professores no marco do Programa de Carreira do Magistério."63

O INEE representa uma ferramenta importante para a federação, os estados e municípios, se estrutura em quatro grandes áreas de trabalho: a) elaborar e brindar indicadores e informação do sistema educacional; b) elaboração de provas de "qualidade" a nível nacional que medem o desempenho de professores e estudantes (ALCÁNTARA, 2011; MÉXICO, 2001, p.100); c) avaliação de recursos e gestão das escolas; d) participação nos projetos internacionais. (CORDERO; LUNA; PATIÑO; 2013).

Entre as provas que o INEE aplicou no seus inícios, figuram os Exames de Qualidade e de Éxito Educacional (Excale) ${ }^{64}(2005)$, o Programa Internacional de Avaliação de Alunos (PISA) 65 coordenado pela OCDE (nos anos 2003, 2006 e 2009) 66 por parte da Direção de Avaliações Internacionais de Resultados Educacionais (DEIRE) ${ }^{67}$ do Instituto, assim como as avaliações das escolas e informes gerais sobre a qualidade da educação básica (ALCÁNTARA, 2011; CORDERO; LUNA; PATIÑO; 2013).

Para sintetizar as principais reformas educativas ocorridas no México de 1992 a 2009, retomamos o documento da Organização para a Cooperação e Desenvolvimento Econômico:

[...] além da «descentralização» e de maneira simultânea, tem-se desenvolvido três processos de reforma educativa, cada uma com sua lógica, seus procedimentos e seus tempos: a) A reforma pedagógica curricular que atingiu à educação infantil, fundamental e secundária (em dois momentos, as reformas de 1993 e as reformas posteriores a 2004 para a educação infantil, de 2006 para a educação secundária e de 2009 para o ensino fundamental); b) A reforma docente - Carreira do Magistério e programas de atualização docente-; e c) A reforma da escola, da sua organização e funcionamento. (ORGANIZAÇÃO PARA A COOPERAÇÃO E DESENVOLVIMENTO ECONÔMICO, 2009, p. 17, grifo nosso, tradução nossa).

\footnotetext{
63 [...] Enlace tenía un enfoque formativo para retroalimentar a maestros, alumnos y padres de familia. [...] Su enfoque ha cambiado y su uso ahora está relacionado con el otorgamiento de estímulos económicos a los maestros en el marco del Programa de Carrera Magisterial.

64 Pelas siglas em espanhol: Exámenes de la Calidad y el Logro Educativo (Excale).

65 Pelas siglas em inglês: Programme for International Student Assessment (PISA). Este é um programa desenvolvido e coordenado pela OCDE, com a finalidade de realizar avaliações comparadas a estudantes do ensino básico, dos países membros.

${ }^{66}$ Este exame é aplicado por vez primeira no México no ano 2000 e brinda indicadores comparativos dos sistemas educacionais dos membros da OCDE que participam nele.

${ }^{67}$ Em espanhol: Dirección de Evaluaciones Internacionales de Resultados Educativos (DEIRE).
} 
Programas de apoio a cada uma de essas reformas têm-se aplicado também conjuntamente desde 1992. Mais detalhes a este respeito, podem encontrar-se em Alcántara (2011); Loyo (2006); México (2001); Organização para a Cooperação e Desenvolvimento Econômico (2009, 2012, 2014).

Como parte da reforma pedagógica curricular, a Reforma Integral da Educação Básica (RIEB) em 2009 -proposta da Aliança pela Qualidade da Educação68 20082012- teve como objetivo articular os três ciclos de ensino básico (educação infantil, ensino fundamental e médio), padronizando os currículos, as práticas pedagógicas e a gestão escolar, especificando as competências e habilidades a serem adquiridas para cada nível de ensino (ORGANIZAÇÃO PARA A COOPERAÇÃO E DESENVOLVIMENTO ECONÔMICO, 2012; TREVIÑO; CRUZ, 2014).

A RIEB se propus fornecer uma educação integral, baseada na pedagogia das competências com o propósito de melhorar o desempenho do estudante e o êxito na sua vida. Para atingir estes objetivos, a RIEB abrange reformas na formação inicial e continua dos professores, e do mesmo modo, nas práticas de qualificação e avaliação docente, sob o mesmo enfoque de competências (ORGANIZAÇÃO PARA A COOPERAÇÃO E DESENVOLVIMENTO ECONÔMICO, 2012; TREVIÑO; CRUZ, 2014).

Entre outros elementos contidos nesta reforma, estão: o estabelecimento do ensino do inglês para a educação infantil e o ensino fundamental; a incorporação de materiais educacionais inovadores, e o estabelecimento de escolas de tempo completo (ORGANIZAÇÃO PARA A COOPERAÇÃO E DESENVOLVIMENTO ECONÔMICO, 2012).

O programa de Escolas de Tempo Completo (presente também na seguinte reforma de 2013), teve como objetivo estender o tempo de escola para favorecer o aprendizado dos estudantes, principalmente daqueles "socialmente menos favorecidos" (MÉXICO, 2009, p.20). Segundo este programa entre mais tempo estudantes e professores dediquem à escola, maior eficiência y eficácia na consecução dos programas de estudo e no aprendizado. E por tanto, maior qualidade da aprendizagem, o objetivo principal.

\footnotetext{
68 Pacto educativo assinado em maio de 2008 pelo governo federal e o SNTE. Este é um documento que estabelece linhas de ação muito gerais, sintetizadas em cinco grandes eixos: "Modernização dos centros escolares, Profissionalização dos professores e das autoridades educativas, Bem-estar e desenvolvimento integral dos alunos; Formação integral dos alunos para a vida e o trabalho e Avaliar para melhorar." (México, 2016).
} 
Em 2008, o governo federal e a OCDE assinaram o Acordo de Cooperação para "Melhorar a Qualidade da Educação nas Escolas no México" (ORGANIZAÇÃO PARA A COOPERAÇÃO E DESENVOLVIMENTO ECONÔMICO, 2010, 2012, 2014), que propõe orientações e recomendações de política educacional para corrigir os problemas ainda presentes no sistema educacional mexicano, como: as altas taxas de evasão na educação básica, melhorar a qualidade dos serviços educacionais, melhorar a organização das escolas, incrementar a autonomia escolar, aprimorar a profissão docente e sua avaliação, e fortalecer a participação social. Ações todas, que impactem nos resultados educacionais, sobretudo nos indicadores do exame PISA (Programme for International Student Assessment). Neste sentido as políticas de gestão escolar e avaliação de estudantes e professores, principalmente, seguiram as pautas descritas neste documento.

Como parte da estratégia de avaliação dos resultados escolares, em 2011 o governo federal propôs mudanças na Carreira do Magistério, expressadas "[...] nas Diretrizes Gerais do Programa Nacional de Carreira Magisterial ${ }^{69}$ em agosto de 2011 [...]". (CORDERO; LUNA; PATIÑO, 2013, p. 4, tradução nossa). Por outa parte, a Aliança pela Qualidade da Educação tinha pactuado os programas de: Estímulos à Qualidade Docente e a Avaliação Universal, que começaram a funcionar em 2011. (CORDERO; LUNA; PATIÑO, 2013).

Conforme Cordero, Luna e Patiño (2013), os três principais programas de avaliação para professores da educação básica em serviço, promulgados desde 1993, são: 1.) Carreira do Magistério; 2.) Estímulos à Qualidade Docente; 3.) Avaliação Universal.

Os principais objetivos destes programas estão focados aos resultados educacionais dos estudantes e aos avanços significativos na aprendizagem. Os resultados das avaliações dos respectivos programas determinam: a.) os estímulos salariais, como premiação pelo desempenho docente na melhora do aprendizado dos estudantes (para o caso da Carreira do Magistério e dos Estímulos à Qualidade Docente); b.) os cursos formativos para a profissionalização docente. Por conseguinte, os dois primeiros programas que estão dirigidos à avaliação das aprendizagens dos estudantes (avaliação somativa) são optativos, e o terceiro dirigido à avaliação formativa ele é obrigatório (CORDERO; LUNA; PATIÑO, 2013).

${ }^{69}$ Lineamientos Generales del Programa Nacional de Carrera Magisterial. 
Pudemos ver, como o SEM, que reúne todas as instituições e elementos educacionais tem tido uma continuidade política desde os anos oitenta, tem sido organizado em função de uma política internacional educacional, com objetivos focados na qualidade da aprendizagem, no desempenho e resultados dos professores e estudantes, e sob o modelo pedagógico baseado no desenvolvimento das competências.

Neste sentido, retomando a Saviani (2000), podemos dizer que as políticas educacionais implementadas no México, não são elaboradas em função de um estudo e conhecimento da realidade educacional e social mexicana. Os diferentes governos federais têm importado políticas internacionais, em troca de financiamento na educação, empréstimos que hoje formam parte da dívida externa do país.

Embora exista conhecimento dos problemas educacionais existentes, como bem diz Saviani (2000) é preciso conhecê-los a detalhe para formular soluções.

No seguinte subitem, analisaremos a atual estrutura do SEM, tomando em conta as mudanças constitucionais na educação, promulgadas pela administração federal 2012-2018. A compreensão do funcionamento do sistema educacional nos ajudará a entender qual o efeito no SEM da reforma educacional 2013.

\subsection{Estrutura atual do Sistema Educacional Mexicano e a Lei Geral de Educação 2013}

Vimos como desde a década dos oitenta, fiel à descentralização educativa e a uma educação básica de resultados e qualidade, cada nova administração governamental tem trazido mudanças legislativas de continuidade com a lógica neoliberal.

Analisaremos brevemente o SEM atual, centrando o estudo na estrutura do sistema de educação básica, para ter os elementos administrativos, técnicos e jurídicos que nos permitam analisar as principais reformas educacionais de 2013 em matéria avaliativa, no subitem 4.3.

O governo federal através da SEP tem instrumentado a política educacional nacional em todos os níveis, em função da legislação e normatividade existente. Os objetivos da educação de cada período sexenal, estão contidos em cada uma de essas políticas públicas, organizando desde essa visão o SEM. 
A descentralização da educação em 1992, transferiu para os estados a administração dos serviços educacionais, conservando a SEP federal, a autoridade para regulamentar e garantir o cumprimento da legislação educacional; a responsabilidade pedagógica (elaboração dos planos e programas de estudo da educação básica e normal, a elaboração e autorização dos livros de texto e o estabelecimento de um calendário escolar ${ }^{70}$ ), avaliativa, financeira, compensatória e laboral do SEM. Mantendo a titularidade nacional do SEM, o governo federal garante o caráter nacional da educação, a equidade na oferta educacional e qualidade da educação a nível nacional, principais objetivos refletidos no artigo $3^{\circ}$ constitucional e nos artigos $2^{\circ}$ e $8^{\circ}$ da LGE (MÉXICO, 2016a; 2016b). Funções que lhe permitem também continuar com o firme controle sobre o SEM. (KRAWCZYK, 2008).

A série de "programas compensatórios", cada vez maiores desde a década dos noventa ${ }^{71}$, foram desenvolvidos com essa finalidade, de ampliar os recursos financeiros para aumentar a cobertura educacional, isto é, dirigidos a equidade na educação (ORGANIZAÇÃO PARA A COOPERAÇÃO E DESENVOLVIMENTO ECONÔMICO, 2014; KRAWCZYK, 2008). Estes providenciam "[...] recursos aos estados em função das carências educacionais." (ORGANIZAÇÃO PARA A COOPERAÇÃO E DESENVOLVIMENTO ECONÔMICO, 2014, p. 21, tradução nossa $)^{72}$.

Os dois principais instrumentos jurídicos do SEM, são 0 artigo $3^{\circ}$ da Constituição Política dos Estados Unidos Mexicanos e a LGE (MÉXICO, 2000). O artigo $3^{\circ}$ constitucional estabelece de maneira geral os direitos educacionais de todos os mexicanos, os objetivos educacionais, a organização do SEM, as atribuições das entidades federal, estatal e municipal respeito à educação; as responsabilidades das escolas públicas e privadas na prestação da educação em todos seus níveis; as diretrizes gerais para o ingresso, promoção e permanência dos professores, e por último, se for o caso, a criação de novos organismos e instituições educacionais (México, 2016a).

\footnotetext{
${ }^{70}$ Funções federais explicitadas no artigo 12 da LGE (MÉXICO, 2016b, p. 6-7)

71 “Já existiam no México programas compensatórios sob responsabilidade do governo central antes da reforma de 1990, com o objetivo de garantir o direito à educação a toda a população, tal como preconizado pelo ideário revolucionário, por meio da cobertura escolar em qualquer lugar do país, principalmente nas regiões mais isoladas." (KRAWCZYK, 2008, p.106).

$72[\ldots]$ recursos a los estados de acuerdo con sus carencias educativas.
} 
A LGE é uma norma diretriz do SEM, formulada a partir dos objetivos constitucionais para a educação, ela regula diretamente a educação pública e privada a nível nacional para alcançar esses objetivos. No seu artigo $1^{\circ}$, parágrafo 1 , ela diz textualmente: "Esta Lei regula a educação que brindam o Estado -Federação, entidades federativas e municípios-, seus organismos descentralizados e os particulares com autorização o com reconhecimento de validez oficial de estudos. É de aplicação geral em toda a República e as disposições que ela contém são de ordem público e de interesse social." (MÉXICO, 2016b, p.1, tradução nossa) ${ }^{73}$.

No México os artigos $3^{\circ}$ constitucional, fracção IV, e 0 artigo $6^{\circ}$ da LGE destacam a gratuidade da educação pública e por tanto o financiamento desta por parte do Estado, nos níveis federal, estadual e municipal. A educação pública laica está refletida no artigo $3^{\circ}$ constitucional, fracção I, e no artigo $5^{\circ}$ da LGE (MÉXICO, 2016a, 2016b), desta forma, corresponde ao Estado brindar uma educação pública, gratuita e laica.

O artigo $10^{\circ}$ da LGE estabelece que a educação ministrada pelo Estado é um serviço público e define assim mesmo, os elementos que integram ao SEM, entre eles destacam-se: os estudantes, professores e pais de família; as autoridades educativas; todas as instituições educacionais a nível nacional; os planos, programas, métodos e materiais educacionais; o Serviço Profissional Docente; a avaliação educacional; o Sistema de Informação e Gestão Educativa e a infraestrutura educacional. (MÉXICO, 2016b).

Observe-se que a participação de novos atores no SEM (professores, estudantes e pais), a avaliação do sistema educacional, assim como o Serviço Profissional Docente, todas elas fracções anexadas em setembro de 2013, têm o objetivo declarado de garantir a qualidade educacional, uma responsabilidade social e não exclusiva do governo (MÉXICO, 2012, p. 2; 2016b).

Com relação a obrigatoriedade dos níveis de ensino, a legislação tem tido modificações, ao longo do tempo. Em 1934 o ensino fundamental de caráter socialista foi estabelecido como obrigatório para todos os mexicanos, porém a reforma de 1946 muda o sentido socialista por uma educação humanista (GONZÁLEZ; FONSECA,

73 Esta Ley regula la educación que imparten el Estado -Federación, entidades federativas y municipios-, sus organismos descentralizados y los particulares con autorización o con reconocimiento de validez oficial de estudios. Es de observancia general en toda la República y las disposiciones que contiene son de orden público e interés social. 
2016; MÉXICO, 2015). Posteriormente em 1993, destaca-se o direito de todo mexicano a receber educação e incorpora-se a educação secundária como obrigatória. Em 2002 se estabelece obrigatória a educação infantil e por último, em fevereiro de 2012, o artigo $3^{\circ}$ constitucional, parágrafo I, determina a obrigatoriedade da educação infantil até a educação média superior (MÉXICO, 2016a). O ensino básico e médio superior são agora obrigatórios para todos os mexicanos, com uma duração de 15 anos (parágrafo II do artigo 4ํ da LGE) ${ }^{74}$, aproximadamente, dos 3 aos 17-18 anos (ver segundo parágrafo da fracção I, do artigo 65, da LGE) ${ }^{75}$.

Na Lei Geral de Educação estabelecem-se três níveis de educação sequencial: a educação básica, a educação média superior e a educação superior; e reconhecemse três modalidades: a escolar ${ }^{76}$, a não escolarizada ${ }^{77}$ e a mista ${ }^{78}$ (artigo 46, da LGE) ${ }^{79}$. Todos eles "serviços" educacionais que podem ser ministrados também por escolas privadas, regidas pela LGE (artigo 10, da LGE) ${ }^{80}$.

Em relação ao ciclo de educação básica, ela compreende: a educação infantil (três anos de duração), o ensino fundamental (seis anos letivos) e o ensino médio (três anos). A educação básica é ministrada por professores das Escolas Normais Públicas, embora para o ensino secundário ele pode ser ensinado por professores universitários. (SECRETARIA DE EDUCAÇÃO PÚBLICA, 2016c).

Atualmente, o SEM, inclui também a educação inicial, como opção educacional, para crianças de 45 dias de nascidas até os quatro anos (artigo 40 da LGE) ${ }^{81}$.

A educação infantil e o ensino fundamental, se organizam em três modalidades: a.) a educação geral, que agrupa as escolas de modalidade escolar localizadas em zonas urbanas e algumas áreas rurais; b.) os cursos comunitários, coordenados pelo Conselho Nacional de Fomento Educativo (CONAFE), de organização multisseriado

\footnotetext{
${ }^{74}$ México (2016c, p. 2).

75 México (2016c, p. 27)

${ }^{76}$ Para este tipo de modalidade precisa-se da presença dos alunos na escola segundo o calendário escolar da SEP.

77 "O serviço não escolarizado tem como objetivo brindar aos alunos que não conseguem incorporarse aos serviços escolarizados a oportunidade de continuar ou concluir sua educação. Este ministra-se através de orientações pedagógicas aos alunos, sem que eles tenham que assistir diariamente à escola." (INSTITUTO NACIONAL DE AVALIAÇÃO EDUCATIVA, 2015, p. 45, tradução nossa).

$78 \mathrm{O}$ sistema de ensino semi-escolarizado, está dirigido às pessoas que trabalham ou que por razões geográficas ou de marginalidade não conseguem assistir regularmente às aulas. Ela "[...] é uma combinação da modalidades escolarizada e não escolarizada, que se caracteriza pela flexibilidade para cursar as disciplinas ou módulos que integram os planos de estudo, seja de maneira presencial ou não presencial [...]". (INSTITUTO NACIONAL DE AVALIAÇÃO EDUCATIVA, 2015, p. 45, tradução nossa).

79 México (2016b, p. 21).

80 México (2016b, p. 4-5).

${ }^{81}$ México (2016b, p.19).
} 
e estão dirigidos às pequenas comunidades rurais e indígenas isoladas, com altos índices de pobreza; c.) a educação indígena -a cargo da Direção Geral de Educação Indígena (DGEI)-, que se caracteriza por ser bilíngue e "bicultural", porém na realidade muitos professores não falam as línguas dos seus alunos nem conhecem sua realidade sociocultural. (INSTITUTO NACIONAL PARA A AVALIAÇÃO DA EDUCAÇÃO, 2015; ORGANIZAÇÃO PARA A COOPERAÇÃO E DESENVOLVIMENTO ECONÔMICO, 2014).

Segundo o informe do Instituto Nacional para a Avaliação da Educação (2015), para o ciclo escolar 2013-2014, o 44.4\%82 do total das escolas de ensino fundamental (43665) no México, eram multisseriadas ${ }^{83}$, isto é, são escolas geralmente localizadas em zonas rurais e indígenas afastadas de difícil acesso, em que um professor trabalha simultaneamente com alunos de diferentes idades e séries do ensino fundamental.

Quanto ao ensino médio, ele compreende cinco modalidades: a) as escolas gerais, que agrupam à "[...] metade da matrícula de alunos, enquanto aproximadamente $028 \%$ dos alunos frequentam uma escola técnica [...]" (ORGANIZAÇÃO PARA A COOPERAÇÃO E DESENVOLVIMENTO ECONÔMICO, 2014, p. 17); b) a escola técnica; c) o sistema de telesecundária ${ }^{84}$, dirigido à adolescentes das zonas semi-urbanas (menos de 2,500 habitantes) ${ }^{85}$ e rurais e oferecido "[...] através de programas especiais de televisão e materiais impressos e digitais, que são complementados com o ensino dos professores." (ORGANIZAÇÃO PARA A COOPERAÇÃO E DESENVOLVIMENTO ECONÔMICO, 2014, p. 17, tradução nossa) ${ }^{86}$; d) os cursos comunitários; e) cursos especiais para adolescentes que trabalham.

A educação média superior se estrutura em dois níveis: a) os ensinos gerais (preparatórias ou bacharelados ${ }^{87}$ ) são cursos com uma duração de dois a quatro anos. Preparam aos alunos para o mercado laboral ou para continuar com os estudos

\footnotetext{
82 Esta porcentagem não tem tido variação nenhuma desde o ciclo escolar 2009-2010 (INSTITUTO NACIONAL DE AVALIAÇÃO EDUCACIONAL, 2012).

${ }^{83}$ No México, se conhecem como escolas de ensino fundamental "multigraus": escuelas primaria multigrados. Para mais informação sobre esta organização de ensino, consultar o documento da Organização das Nações Unidas para a Educação, a Ciência e a Cultura (2003).

${ }^{84}$ Este sistema de ensino foi criado em 1960, com o objetivo de brindar educação à população das zonas rurais e comunidades afastadas.

85 Secretaria de Educação Pública (2016d).

${ }^{86}$ a través de programas de televisión especializados y materiales impresos y digitales, que son complementados con la enseñanza de los maestros.

${ }^{87}$ As "preparatórias e bachilleratos", São os nomes em espanhol destas escolas do ensino médio superior.
} 
superiores; b) os programas professionais técnicos, oferecidos por diversos subsistemas (como o Colégio Nacional de Educação Profissional Técnica, CONALEP), com uma duração aproximada de três anos, que brindam uma formação técnica em diversas especialidades, dirigida ao mercado laboral (INSTITUTO NACIONAL PARA A AVALIAÇÃO DA EDUCAÇÃO, 2015; ORGANIZAÇÃO PARA A COOPERAÇÃO E DESENVOLVIMENTO ECONÔMICO, 2014).

Em tanto a educação superior (técnico professional, graduação e pósgraduação), ela é oferecida em três níveis de formação: institutos e universidades tecnológicos, universidades e escolas normais (ORGANIZAÇÃO PARA A COOPERAÇÃO E DESENVOLVIMENTO ECONÔMICO, 2014, p.16-18).

\section{Quadro 1 - 0 sistema educacional mexicano}

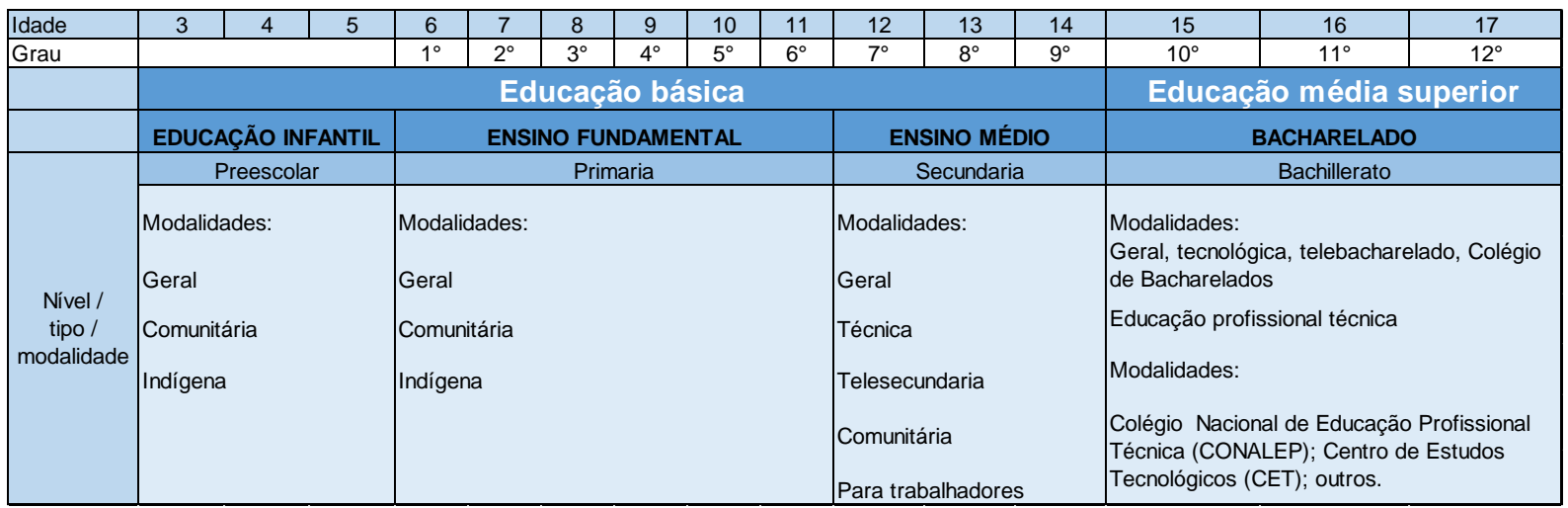

Fonte: ORGANIZAÇÃO PARA A COOPERAÇÃO E DESENVOLVIMENTO ECONÔMICO, 2014.

Os objetivos refletidos na Constituição com respeito a obrigatoriedade da educação básica e média superior contrastam fortemente com a realidade mexicana. Segundo o Instituto Nacional de Avaliação Educativa (2015), a população total estimada para o ano $2013^{88}$, foi de 118 milhões de mexicanos, dos quais o $28.5 \%$ estavam na faixa etária de 3 a 17 anos (33.7 milhões), que correspondem à escolarização obrigatória ditada pela Constituição. Porém, as estatísticas refletem que apenas 30,621,529 das crianças e adolescentes estiveram matriculados, portanto, aproximadamente uns 3 milhões careceram de oportunidades educacionais. Sem uma política social redistributiva, políticas econômicas e sociais dirigidas a resolver as grandes contradições sociais, encontraremos que nos fatos, um grande porcentagem

88 Os últimos indicadores disponíveis correspondem ao ano 2013. 
da população não consegue entrar no SEM ou não conseguem concluir os seus estudos. (INSTITUTO NACIONAL PARA A AVALIAÇÃO DA EDUCAÇÃO, 2015).

Quanto aos objetivos educacionais expressados na constituição, assinalam-se: "[...] desenvolver harmonicamente, todas as faculdades do ser humano y fomentar nele, à vez, o amor à Pátria, o respeito aos direitos humanos e a consciência da solidariedade internacional, na independência y na justiça." Artigo $3^{\circ}$, segundo parágrafo (México, 2016a, p. 3, tradução nossa) ${ }^{89}$.

Retomando a Saviani (2000), uma das caraterísticas que todo sistema educacional tem que ter é uma teoria educacional que plasme a concepção de educação e a guia teórico-metodológica para conseguir o objetivo de formar ao ser humano desde essa perspectiva. Nesta norma constitucional mexicana, podemos apreciar primeiramente que os objetivos educacionais são muito gerais e nacionalistas. Por outro lado, é um parágrafo confuso, porque não se compreende claramente o como, o fomento da solidariedade internacional, se dará ou se relaciona diretamente com a independência e a justiça. Portanto, podemos ver que neste importante artigo constitucional não existe evidencia alguma de uma guia teórica educacional, se propõe o objetivo de desenvolver "todas as faculdades" do homem, sem explicar o que se entende por "faculdades" e o como chegar a esse objetivo.

Por sua vez, na LGE, acrescentam-se objetivos educacionais como aqueles que favorecem ao "desenvolvimento integral do indivíduo", o "desenvolvimento de faculdades para a aquisição de conhecimentos", o "fomento de atitudes que estimulem a investigação e a inovação científicas e tecnológicas", o fomento da leitura, "o conhecimento e a prática da democracia", fortalecer aspectos nacionais e de soberania, conhecimento e respeito das línguas indígenas, valoração da diversidade social e cultural, promoção da justiça, "desenvolver atitudes solidarias nos indivíduos", o fomento da "cultura da transparência e da prestação de contas", entre os mais importantes. (MÉXICO, 2016b, p. 2-3).

Todos estes são também propósitos muito gerais. Brevemente, diremos que os conceitos utilizados: conhecimentos, atitudes e habilidades, se enquadram no enfoque de competências e da teoria do capital humano. Desde esta visão economicista e neoliberal de educação, os estudantes (o fator humano) precisam ser formados

\footnotetext{
89 [...] desarrollar armónicamente, todas las facultades del ser humano y fomentará en él, a la vez, el amor a la Patria, el respeto a los derechos humanos y la conciencia de la solidaridad internacional, en la independencia y en la justicia.
} 
pensando no seu futuro laboral. Isto é, se precisa dotar dos conhecimentos, habilidades, capacidades e competências que o mercado de trabalho precisa. E como vimos no subitem 2.1, a estrutura produtiva atual requere de homens flexíveis que não questionem as condições laborais, nem socioeconômicas. Homens com uma certa qualificação que se traduza num alto desempenho e eficácia para o capital.

Com relação a estrutura da SEP, ela se organiza em quatro grandes áreas: Subsecretaria de Educação Básica (SEB), Subsecretaria de Educação Média Superior (SEMS), Subsecretaria de Educação Superior (SES) e a Unidade de Planejamento e Avaliação de Políticas Educacionais (UPEPE). Igualmente, a SEP administra organismos descentralizados como o Instituto Politécnico Nacional e a Universidade Pedagógica Nacional, que é:

\footnotetext{
(Uma instituição pública de educação superior com mais de 300 unidades no país todo, que participa na formação docente, sobretudo a nível de pósgraduação, quem teve um papel fundamental para melhorar a preparação profissional dos professores, especialmente aqueles que entraram ao sistema sem a graduação). (ORGANIZAÇÃO PARA A COOPERAÇÃO E DESENVOLVIMENTO ECONÔMICO, 2014, p.21, tradução nossa).
}

Outras instituições importantes do SEM são: o Conselho Nacional de Autoridades Educativas (CONAEDU), que tem as funções de planejar a educação e de coordenar as decisões entre o governo federal e os estados; o Instituto Nacional para a Avaliação da Educação (INEE), que tem como responsabilidade garantir a qualidade do SEM; o Centro Nacional para a Avaliação da Educação Superior (CENEVAL), uma organização civil, criada em 1994 com o objetivo de instrumentar, analisar e difundir os exames de conhecimentos, habilidades e competências para a educação média e superior; a Coordenação Geral de Educação Intercultural e Bilíngue (CGEIB), que pretende o estabelecimento de políticas educacionais de inclusão dos povos indígenas em todos os níveis (SECRETARIA DE EDUCAÇÃO PÚBLICA, 2016a), e o Instituto Nacional para a Educação de Adultos (INEA), organismo descentralizado que brinda educação básica a adultos e jovens maiores de 15 anos carentes de estudos ou sem conclui-los (plasmado no artigo 43, da LGE). (ORGANIZAÇÃO PARA A COOPERAÇÃO E DESENVOLVIMENTO ECONÔMICO, 2014; SECRETARIA DE EDUCAÇÃO PÚBLICA, 2016b). 
A nível estadual, estão as Secretarias de Educação estadual, responsáveis pela administração da educação básica (inclui a indígena), da educação especial ${ }^{90}$, e das escolas normais. Os estados organizam conjuntamente com a SEP e o INEE os cursos de atualização, capacitação e desenvolvimento profissional para docentes e a avaliação dos professores em conformidade com a Lei Geral do Serviço Profissional Docente $^{91}$; detêm também a responsabilidade pelo reconhecimento da validez de estudos, e pela autorização do funcionamento e supervisão das escolas privadas, entre as principais funções indicadas nos artigos 13 e 14 da LGE (MÉXICO, 2016b). As instituições estaduais podem participar nos planos e programas de estudo, sempre e quando seja requerido pela SEP para cumprir com os artigos 13, fracção II e 14 fracção II da LGE (MÉXICO, 2016b). Em referência a educação média superior, o artigo 13, fracção VI Bis da LGE, menciona que os estados participarão "[...] na formação e operação de um sistema nacional de educação média superior que estabeleça um marco curricular comum para este nível educativo" (MÉXICO, 2016b, p. 8). A transferência da educação média superior aos estados está sendo muito posterior à educação básica, os primeiros centros escolares em serem transferidos são: os Colégios Nacionais de Educação Profissional Técnica (CONALEP) e os Colégios de "Bacharelados" (ORGANIZAÇÃO PARA A COOPERAÇÃO E DESENVOLVIMENTO ECONÔMICO, 2014).

No que se refere aos municípios, sua atividade no federalismo educacional e no SEM se restringe a questões de infraestrutura, equipamento das escolas e na participação em programas específicos da SEP. Porém eles poderão participar também no estipulado nas fracções V ao VIII do artigo 14 da LGE (MÉXICO, 2016). No entanto, seu papel é mais importante nas comunidades rurais e atualmente nos Conselhos Escolares de Participação Social (ORGANIZAÇÃO PARA A COOPERAÇÃO E DESENVOLVIMENTO ECONÔMICO, 2014).

Como já mencionamos, a participação social na educação é um tema de grande importância para o atual governo federal, gestão 2012-2018. A iniciativa de Decreto que reforma a Constituição Política dos Estados Unidos Mexicanos, menciona que, embora a educação seja uma responsabilidade federal, a qualidade da educação dependerá da participação conjunta da sociedade toda. Esta responsabilidade social

\footnotetext{
90 Para crianças com capacidades diferentes ou superdotadas.

91 Ver México (2013b).
} 
pela educação, e não exclusiva do Estado é expressada nos artigos 65 ao 73 da LGE (MÉXICO, 2012, 2016).

O Conselho Escolar de Participação Social (artigos 68 ao 73 da LGE) é a figura jurídica que possibilita a participação da sociedade em geral, a nível nacional, estadual e municipal, para as escolas conseguirem reunir os fundos necessários para sua manutenção, assim como para organizar as atividades voltadas ao trabalho voluntario nas escolas. Ações escolares e sociais que fortaleçam a qualidade e equidade da educação pública (MÉXICO, 2016b; ORGANIZAÇÃO PARA A COOPERAÇÃO E DESENVOLVIMENTO ECONÔMICO, 2014).

Existe também a figura do Conselho Técnico Escolar, que é um órgão de caráter consultivo composto no mínimo por 5 professores e dirigido pelo diretor da escola para o ensino fundamental e no caso do ensino secundário se inclui também o subdiretor. Estes conselhos permitem a participação dos presidentes estudantis e representantes dos pais de família na discussão de assuntos técnico-pedagógicos principalmente (MÉXICO, 2010; ORGANIZAÇÃO PARA A COOPERAÇÃO E DESENVOLVIMENTO ECONÔMICO, 2014).

Em cada escola a autoridade principal é o diretor, nele está a responsabilidade da administração e gestão escolar. O controle administrativo e técnico-pedagógico em cada estado está dirigido pelo sistema de supervisão escolar dividido por setores e zonas. Cada setor conta aproximadamente com 10 zonas, e cada zona compreende entre oito e vinte escolas. Os inspetores ou supervisores, fiscalizam as escolas, proporcionam ajuda na organização escolar e atuam como ponte entre as autoridades estaduais e federais com as escolas (MÉXICO, 2010; ORGANIZAÇÃO PARA A COOPERAÇÃO E DESENVOLVIMENTO ECONÔMICO, 2014).

O ingresso, promoção, reconhecimento e permanência dos professores, diretores de escolas, supervisores e chefes de setores da educação básica e média superior, ministrada pelo Estado, são obtidos desde 2013 mediante "concursos de oposição" e avaliações obrigatórias, todos eles, diretrizes estabelecidas na Lei regulamentária do Serviço Profissional Docente do 11 de setembro de 2013 (fracção III do artigo $3^{\circ}$ constitucional, nos artigos 12, 14, 20 e 21 da LGE, na Lei Geral do Serviço Profissional Docente, no apartado B do artigo 123 constitucional e na Lei 
Federal dos Trabalhadores ao Serviço do Estado) ${ }^{92}$. Esta reforma adicionada em 2013, será objeto de análise no seguinte subitem.

\section{Quadro 2 - Concorrência pública de provimento e progressão para o magistério público}

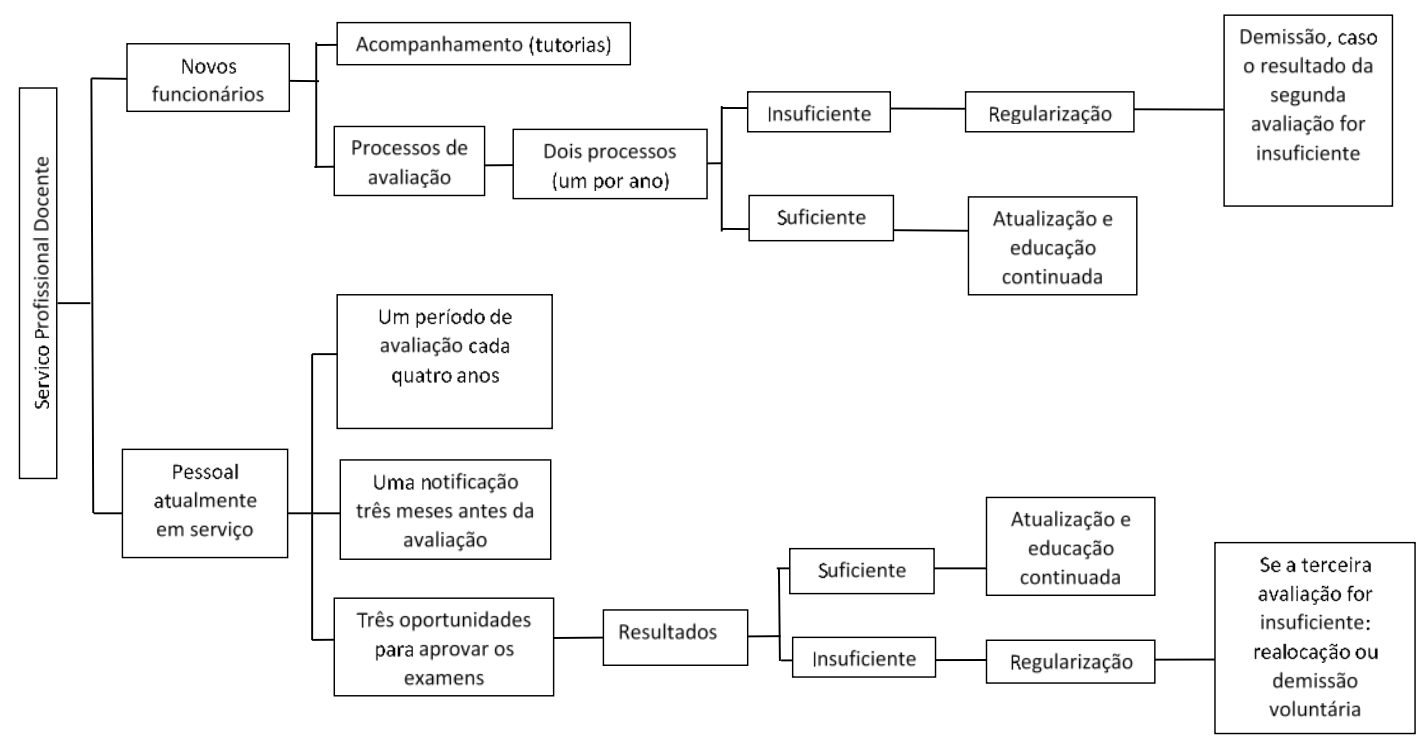

Fonte: INSTITUTO NACIONAL PARA A AVALIAÇÃO DA EDUCAÇÃO, 2015b.

Anteriormente o sistema de carreira para a educação básica se realizava mediante um sistema de promoção vertical, conhecido como "escalão" 93 ", que permitia ao pessoal com mais antiguidade e com uma categoria imediatamente anterior, solicitar e concorrer para uma posição maior. As nomeações eram definitivas.

A avaliação dos professores para ocupar as diferentes posições laborais, está a cargo do Instituto Nacional de Avaliação Educacional (INEE), criado em 2002. A autonomia que tem desde 2013, Ihe possibilita tomar decisões de caráter técnico, para elaborar e instrumentar o Sistema Nacional de Avaliação Educativa. O INEE será objeto de análise no seguinte capítulo.

Em relação ao financiamento da educação, segundo o Instituto Nacional de Avaliação Educativa (2015), a porcentagem de crescimento do gasto público em educação no período de 1990 a 1999 cresceu a um ritmo de 4.63\%, e de 2000 a 2009 de $6.15 \%$ do Produto Interno Bruto (PIB). Porém, esta tendência diminuiu a tal grau

\footnotetext{
${ }^{2}$ México (2016a; 2016b; 2013a; 2013b).

${ }^{93}$ Escalafón, em espanhol.
} 
que em 2013 apenas alcançou o 0.6\% e em 2014 o 0.3\%, ainda quando em 2013 e 2014 o PIB teve um crescimento a uma taxa de $1.3 \%$ e $2.6 \%$ respetivamente.

Retomando a Saviani (2000), podemos afirmar que a organização do sistema educacional mexicano não tem sido um produto social, por não expressar os interesses comuns do povo mexicano. Ele também não está organizado em função das necessidades sociais e educacionais. Nos encontramos no fato, com uma pedagogia importada e homogênea, no sentido que as prescrições educacionais dos organismos internacionais são as mesmas a nível internacional. Por tanto concluímos, assim como Saviani (Ibid.) para o caso educacional brasileiro, que sem um objetivo educacional plasmado na Constituição mexicana, com princípios sociais, sem um objetivo baseado na análise do sistema educacional mexicano, e sem uma teoria educacional que guie o processo educativo, não podemos falar da existência de um sistema educacional mexicano. Nos encontramos com um conjunto de instituições educacionais que atuam em função de objetivos educacionais internacionais que respondem a interesses econômicos e políticos, e que obviamente não correspondem aos objetivos sociais, nem à realidade educativa mexicana. A lógica capitalista está presente nesses objetivos, na administração e na organização educativa no México

Porém, os problemas educacionais não estão sendo atendidos nem solucionados. Os conflitos educativos, pensando no processo educacional como um processo laboral e um processo de ensino e aprendizagem, estão crescendo. O movimento do magistério dos professores do ensino básico e agora (há uns três anos) a participação dos pais de família e estudantes, são uma amostra do descontentamento social.

Tomando em conta estas reflexões, analisaremos no seguinte subitem o lugar que tem a reforma educacional 2013 nesse chamado sistema educacional mexicano.

\subsection{Análise das principais mudanças legislativas da Reforma Educativa 2013 no México}

Resulta interessante sublinhar como as alianças com o Sindicato Nacional de trabalhadores da Educação (SNTE) ou com os principais partidos políticos no México, 
tem sido formas de encobrir a regulamentação ${ }^{94}$ de uma política presidencial e neoliberal de educação, sem contar com a participação da comunidade escolar nem da sociedade para discutir o projeto educacional que se quer; e por outra parte implica, uma política de transmissão da responsabilidade da educação à sociedade.

Desde o ANMEB de 1992 até a "reforma educativa 2013", os presidentes em turno têm negociado com esses e outros atores políticos e econômicos. Assim por exemplo, no sexênio presidencial 2000-2006, o Compromisso Social para a Qualidade da Educação, foi um documento assinado entre o governo federal e diversos setores da sociedade o dia 8 de agosto de 2002 -como as autoridades educacionais, o SNTE, os governadores, os empresários, as organizações civis, fundações (como "Vamos México"), e os representantes das igrejas católica, judia e ortodoxa (ENCABEZA..., 2002) - com o objetivo de buscar consensos, objetivos e compromissos unificados na educação para garantir a qualidade com equidade para o século XXI (ARIAS; BAZDRESCH, 2003; ENCABEZA...,2002). Posteriormente, como mencionamos no apartado passado, no período presidencial 2006-2012, a Aliança pela Qualidade da Educação (ACE), é pactuada em maio de 2008 com o SNTE para impulsar o processo de reforma educacional, nela se destacam a profissionalização dos professores e a avaliação de professores, alunos e do sistema educacional todo. Nesse mesmo ano, é assinado também o acordo de cooperação com a OCDE, que representa um acordo de grande envergadura com um organismo internacional na educação.

Todas as políticas pactuadas com estes grupos sociais e os organismos internacionais (Banco Mundial e OCDE, principalmente) têm sido implantadas ${ }^{95} \mathrm{e}$ posteriormente implementadas ${ }^{96}$ em cada período presidencial, e curiosamente os problemas educacionais descritos em cada Plano Nacional de Desenvolvimento para

\footnotetext{
94 Retomando a Gomes (2012, p. 26), a regulamentação "[...] diz respeito aos dispositivos legais que expressam as ações a serem adotadas pelos Conselhos e pelas Secretarias de Educação para desencadear e realizar a implementação da Lei [...]".

95 "O início de toda e qualquer política pública atravessa um momento inaugural, uma etapa de apresentação de uma perspectiva que se abre à sociedade, denominado implantação. Em geral, nessa fase, a regulamentação do que está proposto pela política ou pela legislação dela decorrente ainda se encontra em debate a dependente da análise das condições que dificultam ou facilitam essa fundação -identificação dos recursos necessários, parcerias na sociedade civil, posicionamentos políticos sobre o tema, identificação de tensões." (GOMES, 2012, p. 26).

96 "Decorrente dessa etapa inaugural é a capacidade de implementação da política, da execução de um plano, programa ou projeto que leve à sua prática por meio de providências concretas. Ao distinguir esses dois momentos não se pretende realizar uma passagem estanque e linear entre a implantação e a implementação. São momentos interdependentes, que, conforme a concepção da legislação em questão, podem se dar como movimentos contínuos." (GOMES, 2012, p. 26).
} 
cada sexênio continuam reproduzindo-se e aprofundando-se, como também as mesmas políticas educacionais neoliberais dirigidas à qualidade do ensino.

Quanto às reformas educacionais promulgadas em 2013, elas também são fruto de acordos políticos e empresariais nacionais e internacionais. Segundo Aboites (2013), Coll (2013) e Hernández (2013), o grupo empresarial "Mexicanos Primero", presidido por Claudio X. González, pediu em 10 de setembro de 2012 (HERNÁNDEZ, 2013) ao então candidato presidencial eleito ${ }^{97}$ Enrique Peña Nieto realizar quatro mudanças na educação: a.) a recuperação da governabilidade na educação; b.) a profissionalização docente, pondo a concurso público todas as vagas para o pessoal da educação e como obrigatória a avaliação universal a professores; c.) maior autonomia das escolas e d.) eliminar os apoios governamentais para as vagas sindicais da educação (HERNÁNDEZ, 2013).

Estas condições formaram parte da "reforma educativa 2013", e sua implantação foi possível, graças ao Pacto por México, uma aliança nacional entre o Presidente da República e os três principais partidos políticos PRI, PAN, e PRD, assinada o 2 de dezembro de 2012. Nela, pactuou-se uma "Educação de qualidade e com equidade ${ }^{98 "}$, com três objetivos principais: 1.) a melhora da qualidade da educação básica, medida pelos resultados no exame PISA, 2.) Aumento da matrícula escolar e melhoria da qualidade na educação média superior e superior, e 3.) recuperação da governabilidade no SEM, mantendo o princípio fundamental de laicidade (PACTO POR MÉXICO, 2016).

As principais ações propostas nesse documento para atingir os três objetivos foram: a criação de um Sistema de Informação e Gestão Educacional, com um censo de escolas, professores e alunos, informação contida numa plataforma única que possibilite a melhora no funcionamento do SEM; a consolidação do Sistema Nacional de Avaliação Educacional, outorgando plena autonomia ao INEE, e uma função de autoridade avaliativa nacional; fortalecimento da autonomia de gestão das escolas sob a liderança dos diretores de escolas, com o objetivo de melhorar as condições de infraestrutura, material e equipo educacional e de gestão; o estabelecimento das escolas de tempo completo, com uma extensão do tempo acadêmico de 6 a 8 horas diárias; a criação de um Serviço Profissional Docente,

\footnotetext{
${ }^{97}$ Eleições amplamente questionadas, pelo escândalo de compra de votos e de fraude eleitoral, cenário político crítico em meio de uma crise econômica profunda.

${ }^{98}$ Educación de calidad y con equidad.
} 
com base numa política de concurso público e de bonificação por resultados, tanto para professores como para diretores e supervisores; melhoras na profissionalização inicial da docência; melhoras no incremento do gasto público para aumentar a cobertura da educação média superior e superior; e a criação de um Programa Nacional de Bolsas para alunos da educação média superior e superior ${ }^{99}$.

A partir desta agenda educacional, em 10 de dezembro de 2012, o presidente envia para a Câmara dos Deputados a "Iniciativa de Decreto que reforma e adiciona diversas disposições da Constituição Política dos Estados Unidos Mexicanos" que implica modificações aos artigos $3^{\circ}$ constitucional ${ }^{100}$ e 73 fracção XXV ${ }^{101}$, e reformas na Lei Geral de Educação (MÉXICO, 2012). Estas propostas de reforma educacional são aprovadas na Câmara baixa do Congresso da União no dia 19 de dezembro de 2012, e posteriormente elas serão ratificadas no Senado Federal -com certas modificações ${ }^{102}$ - o dia 21 de dezembro desse mesmo ano (HERNÁNDEZ, 2013; REFORMA..., 2016).

No dia 6 de fevereiro de 2013 a reforma educacional é declarada constitucional pelo Congresso da União, e o 25 de fevereiro ela é promulgada pelo Presidente, os integrantes do Pacto por México e pelo Secretário da Educação Pública, Emilio Chuayffet. A "reforma educativa" será finalmente publicada no Diário Oficial da Federação o dia 26 de fevereiro de 2013 (HERNÁNDEZ, 2013; MÉXICO, 2016; REFORMA..., 2016).

Como pudemos apreciar, a chamada reforma educacional 2013 foi concebida e aprovada em apenas um mês. Em dezembro de 2012, a educação nacional, um tema de grande transcendência para o povo mexicano é definida e organizada por um pequeno grupo de políticos e empresários nacionais e internacionais. Autores vários salientam a rapidez desse processo (ABOITES, 2013; COLL, 2013; HERNÁNDEZ, 2013) e sinalam a impossibilidade de considerar como reforma educacional às mudanças constitucionais aprovadas em 2012 e 2013 por carecer de legitimidade

\footnotetext{
99 Mais informação a este respeito pode ser encontrada em Pacto por México (2012, p. 4-6). 100 Reformas no artigo $3^{\circ}$ da Constituição Política dos Estados Unidos Mexicanos fracções II, III, VII e VIII, e são adicionados o terceiro parágrafo, o inciso d) da fracção II, e a fracção IX que garante a criação de um Sistema Nacional de Avaliação Educacional que esteja coordenado pelo INEE, organismo que gozará de autonomia. (MÉXICO, 2016a

101 Referente às faculdades do Congresso da União para a criação de um Serviço Profissional Docente, conforme ao artigo $3^{\circ}$ da Constituição Política dos Estados Unidos Mexicanos. (MÉXICO, 2016b, p.67). 102 Para mais detalhes ver os seguintes documentos: (HERNÁNDEZ, 2013; REFORMA..., 2016).
} 
social e por não conter os elementos pedagógicos e administrativos em função da realidade e problemática educacional mexicana (CNTE, 2013; COLL, 2013).

Como mencionamos no capítulo anterior, o suposto objetivo das reformas educacionais no México desde 1992 até 2013, é a qualidade da educação, fazendo ênfase na aprendizagem por competências. As mudanças educacionais de 2013, são em realidade elementos técnicos, administrativos e avaliativos já contidos em "reformas" educacionais previas, mas agora convertidas em diretrizes constitucionais. (COLL, 2013).

O grande objetivo de todas estas reformas educacionais, tem sido a consecução do crescimento econômico via a universalização da educação, tal e como se menciona nos documentos da UNESCO ${ }^{103}$ (ORGANIZAÇÃO DAS NAÇÕES UNIDAS PARA A EDUCAÇÃO, CIÊNCIA E CULTURA, 1994; 2014).

Diante do chamado processo de globalização, da liberalização econômica e da sociedade do conhecimento, nos anos noventa organismos internacionais como a UNESCO, o Banco Mundial, o BID e a OCDE, promoveram com mais força nos países latino-americanos os postulados econômicos do capital humano para a educação. Isto é, o investimento em educação, para aumentar a produtividade do capital humano, um fator econômico de grande peso que possibilita o progresso econômico.

Segundo a teoria do capital humano, os investimentos na educação associados com a equidade educacional, minimizariam as disparidades regionais uma vez que elevariam a produtividade do trabalho favorecendo o desenvolvimento da economia toda. O fator capital humano, entendido como: o nível de escolaridade ou qualificação, as habilidades adquiridas e a acumulação de conhecimentos gerais ou específicos dos sujeitos, explicariam tanto a quantidade como a qualidade do crescimento econômico no longo prazo. Desde esse enfoque, num mundo globalizado e cada vez mais competitivo, resulta imprescindível que os países latino-americanos invistam na formação de capital humano e implementem políticas públicas educacionais com altas exigências para regulamentar os padrões de qualidade desse importante fator de produção (VIANA; FERRERA, 2010).

Esta noção econômica de educação fez parte do discurso de posse do atual presidente Enrique Peña Nieto ${ }^{104}$. É aqui, parte do discurso: "Sétima decisão. Há

103 Referido na Conferência Regional para a Educação Gratuita e Obrigatória na América Latina, em 1956.

${ }^{104} \mathrm{Na}$ tomada de posse do $1^{\circ}$ de dezembro de 2012. 
chegado o momento de uma reforma educacional. Uma nação baseia seu desenvolvimento na educação. O capital humano é a base do desenvolvimento e progresso de um país; é esta a razão que corresponde ao Estado a reitoria da política educacional." (DISCURSO..., 2012, tradução nossa) ${ }^{105}$. Nesta mensagem já estava marcada a reforma educacional a seguir.

Seguindo as propostas destes organismos internacionais, a reforma educacional no México, que nós nos referimos como "reforma educativa 2013" -por ser declarada constitucionalmente e começar seu processo de implantação no ano 2013- contem como principais modificações constitucionais:

a) a criação do Instituto Nacional para a Avaliação da Educação (INEE) como órgão constitucional autônomo. Se constitui este Instituto como a máxima autoridade avaliativa nacional (fracção IX do artigo $3^{\circ}$ constitucional e artigo 27 da Lei do Instituto Nacional para a Avaliação da Educação) ${ }^{106}$, com o objetivo de garantir a qualidade na educação obrigatória básica e média superior (artigo 11, da Lei do Instituto Nacional para a Avaliação da Educação), tendo a responsabilidade de coordenar o Sistema Nacional de Avaliação Educativa (artigos 14, 25 e 27, da Lei do Instituto Nacional para a Avaliação da Educação) junto com outras autoridades educacionais federais e estatais públicas e privadas (artigos 11 e 16, da Lei do Instituto Nacional para a Avaliação da Educação). (MÉXICO, 2013c).

b) a institucionalização do Serviço Profissional Docente (SPD). Que consiste na regulamentação do Serviço Profissional Docente, para o ingresso e promoção por concurso, para cargos de professor, direção e supervisão na educação básica e média superior; para regular o reconhecimento e permanência no serviço docente; estabelecendo os mecanismos de formação, atualização, capacitação e superação profissional dos professores do ensino básico e média superior, para garantir os conhecimentos e capacidades necessárias e portanto a qualidade do sistema educacional (fracção III do artigo $3^{\circ}$ Constitucional, artigos 1, 2, 3,

\footnotetext{
105 Séptima decisión. Ha llegado el momento de la Reforma Educativa. Una nación basa su desarrollo en la educación. El capital humano es la base del desarrollo y progreso de un país; esta es la razón por la que corresponde al Estado la rectoría de la política educativa.

106 México (2016a; 2013c).
} 
13, 21, 22, 26, 34, 45, 52 e 53 da Lei Geral do Serviço Profissional Docente) ${ }^{107}$.

c) a criação do Sistema de Informação e Gestão Educativa (SIGED). Que tem por objetivo "[...] regular, coordenar e operar um padrão de alunos, docentes e instituições e centros escolares; um registro nacional de emissão, validação e inscrição de documentos acadêmicos, e para estabelecer um Sistema Nacional de Informação Educativa." (MÉXICO, 2013a, p.2; 2016b $\left.{ }^{108}\right)$.

Para estas mudanças educacionais promulgaram-se dois novos marcos jurídicos: A Lei do Instituto Nacional para a Avaliação da Educação e a Lei Geral do Serviço Profissional Docente.

Entre as principais leis regulamentadoras ${ }^{109}$ da reforma educacional, destacam-se:

a) a autonomia da gestão das escolas. Trata-se das normativas que fortalecem a autonomia escolar na educação básica para:

\begin{abstract}
Administrar de forma transparente e eficiente os recursos que receba para melhorar sua infraestrutura, comprar materiais educacionais, resolver problemas de operação básicos e propiciar condições de participação para que os alunos, professores e pais de família, sob a liderança do diretor, se involucrem na solução dos desafios que cada escola enfrenta. (MÉXICO, 2016b, p.15, tradução nossa) ${ }^{110}$.
\end{abstract}

b) as escolas de tempo completo. Estabelecem-se legalmente, jornadas acadêmicas de entre 6 a 8 horas, com o objetivo de melhorar 0 desenvolvimento acadêmico, esportivo e cultural dos estudantes. As escolas irão-se incorporando paulatinamente a este sistema, segundo as suas possibilidades orçamentais. Esta lei está plasmada na fracção XVI do artigo 33 da LGE (MÉXICO, 2016b, p. 18).

107 México (2016a; 2013b).

108 Fracção X do artigo 12, e fracção VII do artigo 13, da Lei Geral de Educação.

109 Leis regulamentadoras aprovadas em setembro de 2013.

110 Artigo 28 bis da Lei Geral de Educação. A autonomia da gestão escolar está também refletida na fracção XII Bis do artigo 12 da Lei Geral de Educação. 
Estas mudanças todas correspondem à visão gerencialista na educação referida na literatura (BALL, 2001; 2008; GARCIA; ADRIÃO; BORGHI, 2009; MOREIRA, 2010; PEIXOTO, 1996; PERONI; DE OLIVEIRA; FERNANDES, 2009; ROBERTSON; VERGER, 2012; RUSSO, 2004; KRAWZCYK, 2005; XAVIER, 1991), nela salientam-se: a diminuição do orçamento público para a educação; a descentralização financeira e administrativa educacional para os estados e municípios; a autonomia financeira e administrativa das escolas e a participação da "comunidade" no financiamento da educação (parcerias público-privadas), a equidade e qualidade da educação são agora uma responsabilidade social; a educação focada nos resultados; a legalização de sistemas de avaliação educacional homogêneos, na figura do INEE, como uma forma de controle governamental da educação. Responsabilidade partilhada com parceiros privados nacionais e internacionais (PISA, CENEVAL); estão presentes também as políticas de regulação da qualidade, do desempenho e da competitividade dos docentes e alunos, refletidas nas diversas avaliações que lhes são aplicadas. Políticas que tem a finalidade de subordinação e controle; a fragmentação do trabalho, entanto os professores são obrigados a cumprir com programas de estudo estabelecidos desde a SEP e a aplicar exames desenhados por organismos nacionais e internacionais externos; uma subsunção formal e real dos professores da educação: uma extensão do trabalho laboral (com as escolas de tempo completo), baixos salários, condições precárias de trabalho, um forte controle dos gerentes (diretores) e do Estado, em conjunto com uma "[...] fragmentação e hierarquização do trabalho pedagógico [...]" (PEIXOTO, 1995, p. 46), políticas gerencias toyotistas em busca da racionalidade, eficiência, eficácia e produtividade do "mercado educacional".

Em base ao referido, podemos dizer que estas políticas educacionais são uma forma "encoberta" para descentralizar a educação para o mercado. (BALL, 2008; KRAWCZYK, 2005). 


\section{Quadro 3. Configuração da reforma constitucional 2013, artigo $3^{\circ}$}
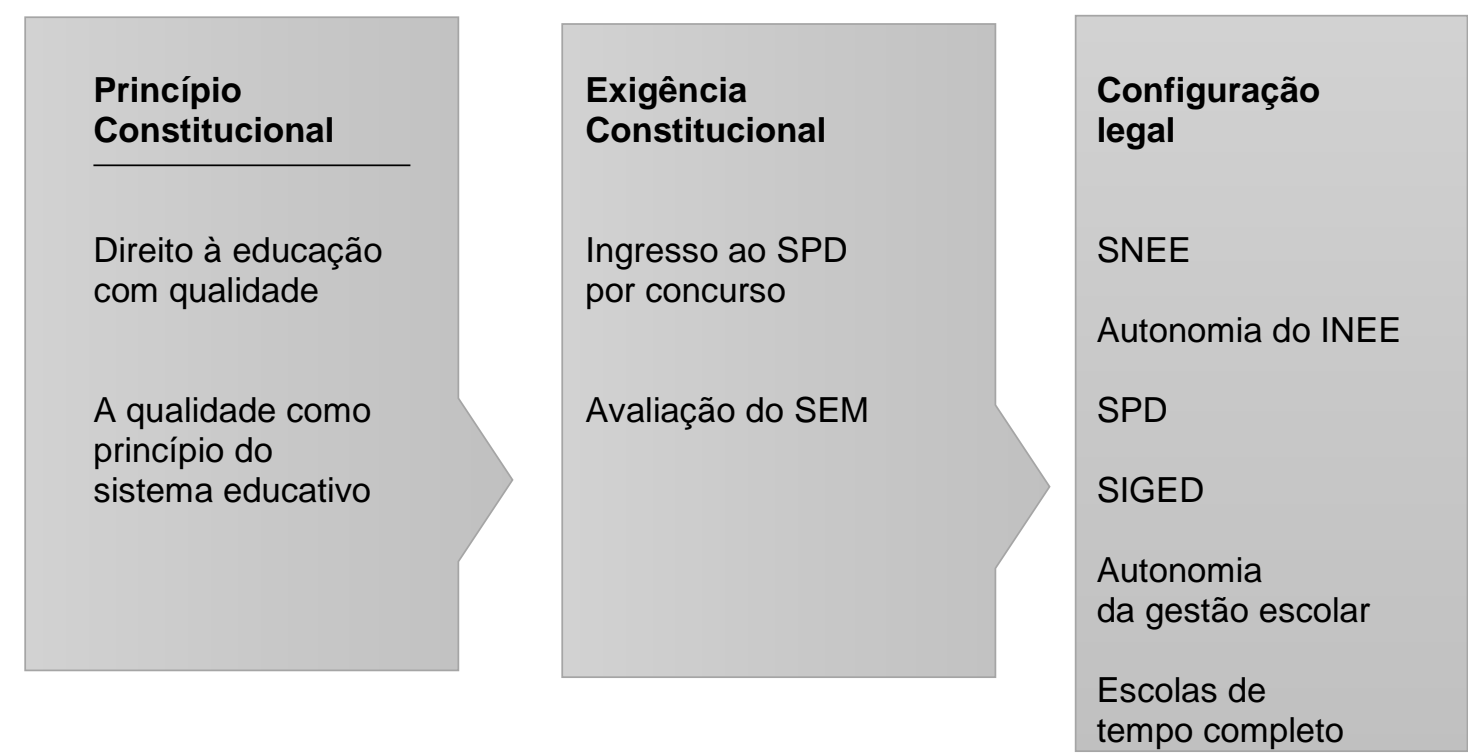

Fonte: INSTITUTO NACIONAL PARA A AVALIAÇÃO DA EDUCAÇÃO, 2015b.

A resistência do magistério pertencentes à Coordenadora Nacional de Trabalhadores da Educação (CNTE) -um grupo de professores que está contra a corrupção do SNTE dirigido até o mês de fevereiro de 2013, por Elba Esther Gordillo ${ }^{111}$ - em aceitar a "reforma educativa 2013" por ela representar um retrocesso no âmbito pedagógico e laboral, estendeu o processo de implantação da reforma até 2014. Ao longo do ano 2013 Organizaram-se diferentes foros de discussão e negociação entre os professores da educação básica (principalmente) e o governo federal.

Sem tomar em conta, as demandas dos professores a respeito da reforma educativa, em setembro de 2013 foram aprovadas autoritariamente as leis regulamentadoras. A implementação da reforma, começou em 2014 -sem o consenso da comunidade educativa-, com a aplicação das primeiras avaliações à professores no ciclo escolar 2014-2015 (BACKHOFF; GUEVARA, 2015).

Este importante processo contra hegemônico dos professores da educação básica no México, será descrito no capítulo 4. Passaremos a analisar com mais detalhe as repercussões da reforma educativa 2013.

\footnotetext{
111 Em 1989, assume por mandato presidencial (Carlos Salinas de Gortari) a Secretaria Geral "vitalícia" do Sindicato Nacional de Trabalhadores da Educação (SNTE), um dos sindicatos mais poderosos de América Latina. Ela atuará como uma incondicional do poder. O amplo poder que ela tinha não convinha mais ao governo, e em fevereiro de 2013 ela é detida e presa. A detenção de Elba Esther, foi uma mensagem política do presidente Enrique Peña Nieto para todos os líderes sindicais. (BARRIENTOS; AÑORVE, 2014).
} 


\subsection{Os princípios teóricos, econômicos e políticos contidos na reforma educativa 2013 no México}

A reforma educativa 2013 é uma reforma de caráter administrativo e laboral, sem contribuições de caráter pedagógico, centrada nos conceitos de eficiência, de resultados, de avaliação e de competência, para uma qualidade educacional.

Estas mudanças educacionais chamadas de "reformas modernizadoras" formam parte da visão gerencial capitalista transferida à escola. A função da escola é a socialização do saber sistematizado, mas como instituição social pertencente a uma estrutura econômica, ela serve à classe social hegemônica, que detém o poder (PARO, 2014).

Em todo modo de produção, a administração como atividade social mediadora, é necessária na consecução dos objetivos a serem cumpridos utilizando "[...] racionalmente os meios de que dispõe para realiza-los." (PARO, 2014, p. 25). No capitalismo, a administração escolar é vista como um instrumento de poder, em que os objetivos econômicos determinam os objetivos educacionais, isto é se impõe uma "filosofia de educação" condizente com seus interesses de classe (PARO; 2014). No capitalismo a administração escolar servirá aos interesses capitalistas e não aos interesses sociais educacionais.

Enquanto a administração capitalista tem como objetivo o lucro (para a ampliação do capital), os fins da educação -como direito social e universal- são a apropriação da cultura humana, a formação de sujeitos conscientes que se envolvam na transformação social (LEONTIEV 1978; VIGOTSKI, 2015). Está claro que no capitalismo, não interessa formar a esse homem integral. No capitalismo, a educação tem sido vista como fonte de preparação da força de trabalho -para um mercado de trabalho que perpetua e aprofunda as relações sociais, às classes sociais-, e ao mesmo tempo ela tem sido utilizada como instrumento estatal para a reprodução de valores e de ideologia que reproduzem esse mesmo sistema econômico. Mudar esta situação precisa de "soluções essenciais" que " [...] abranjam a totalidade das práticas educativas da sociedade estabelecida." (MÉSZAROS, 2008, p.40), e não assim de simples reformas educacionais que se guiam por objetivos capitalistas. Do mesmo modo que Gramsci (2009), Mészáros (Ibid.) assinala que enquanto exista um "Estadoclasse" e se mantenha a mesma estrutura econômica de fundo, não poderá existir uma igualdade política, que edifique uma sociedade mais justa. Porém, eles 
reconhecem a importância que tem a educação, como processo ativo na "autotransformação consciente" das pessoas que possibilite "transcender a alienação do trabalho" e de transformar a estrutura da sociedade (MÉSZÁROS, 2008, p.60).

Neste sentido, Saviani (2008), menciona, que nem todas as forças econômicas e políticas do sistema, tem impossibilitado reduzir a educação a simples diretrizes de esvaziamento cultural. A escola pública resulta ser um espaço frutífero de apropriação de saber, que permite tanto a professores como alunos se questionar sobre a ação educacional como sobre as relações sociais desiguais, que se estabelecem dentro e fora da escola. O questionamento das relações de poder e hierarquia que permeiam todas as instituições, e que se legalizam mediante Leis constitucionais que legitimam as práticas sociais.

Um exemplo desta situação é o movimento do magistério do ensino básico no México, que com a promulgação da reforma educativa em 2013, estão participando ativamente na toma de consciência da população sobre os verdadeiros objetivos educacionais que se encobrem nessas chamadas Leis educacionais. Pais de família, acadêmicos de instituições públicas e parte da população, está sendo partícipes deste processo.

Como primeiro ponto, eles não reconhecem a reforma educacional por carecer de legitimidade, enquanto não foi construída desde um conhecimento real da problemática educativa e social do país nem desde as bases acadêmicas e sociais, senão desde os objetivos dos "reformadores empresariais na educação" como Mexicanos Primero e "Muévete por la Educación", e também, desde organizações internacionais como a OCDE. (COORDENADORA NACIONAL DE TRABALHADORES DA EDUCAÇÃO, 2013).

Como mencionamos nos subitens 2.1, 4.1 e 4.2, as políticas educacionais que se tem implementado no México desde os anos oitenta do século passado, formam parte das "recomendações econômicas" e das políticas de crédito à educação dos organismos internacionais, porta-vozes do capital.

Com os discursos de equidade, qualidade e competitividade na educação para um crescimento e desenvolvimento econômico, coloca-se no sistema educacional, a responsabilidade econômica e redistributiva social. Se impulsionam políticas de investimento em educação (com projetos educacionais dirigidos desde estes organismos) para conseguir a universalidade do ensino básico e se propõem medidas financeiras e administrativas eficazes na consecução destes objetivos. 
Neste sentido, os processos de descentralização com centralização (com um forte e rígido controle Estatal) na educação têm sido os elementos presentes nas reformas educacionais no México (e a nível internacional).

A descentralização desde esta visão neoliberal, brinda às escolas autonomia para a alocação eficaz dos recursos econômicos e materiais. No México, com a Lei de autonomia escolar, se pretende legitimar e naturalizar a participação econômica de organismos privados no financiamento educacional, ao tempo que o Estado diminui sua participação como responsável financeiro. Ainda quando no artigo $3^{\circ}$ constitucional, se assinale a obrigação exclusiva do Estado no financiamento da educação pública (MÉXICO, 2015a, p. 6).

Uma vez que o Estado outorga a "liberdade" para a "mobilização e alocação" dos recursos públicos às escolas e a "liberdade" à sociedade para participar nos assuntos econômicos escolares (artigos 65 ao 73 da LGE) ${ }^{112}$, o Estado faculta a inserção das escolas no capital privado.

O processo de centralização que se dá junto com a descentralização, tal como é referido por Ornelas (apud ORGANIZAÇÃO PARA A COOPERAÇÃO E DESENVOLVIMENTO ECONÔMICO, 2014), garante a implementação das políticas neoliberais na educação. O Estado concentra o poder para "definir sistemas nacionais de avaliação, promover reformas educacionais, estabelecer parâmetros de um Currículo Nacional e estabelecer estratégias de formação de professores centralizados nacionalmente." (ARCE apud JUNQUEIRA, 2014, p. 120), todas elas instrumentadas desde os organismos internacionais.

Desde a visão gerencial e neoliberal da educação, a avaliação dos resultados (da aprendizagem), tem um papel essencial na política de transparência e eficácia financeira. Trata-se de controlar todos "os componentes do sistema" educacional (ABOITES, Hugo, 2013, p.30) para uma racionalização eficiente dos recursos, que assegurem uma qualidade educacional. Qualidade, que será medida por indicadores específicos de desempenho.

Neste sentido, a Lei constitucional do INEE (MÉXICO, 2013c), Ihe outorga poder e legitimidade a esse organismo avaliador, para elaborar e aplicar a nível nacional avaliações a professores e alunos, para sua mensuração e classificação e determinar assim, seu nível de desempenho. Para Coll (2013), no caso dos

112 México (2016b). 
estudantes, estas "medições de aprendizagem" longe de servir a uma retroalimentação do sistema educacional, estão servindo para uma classificação e seleção dos alunos e das escolas; outorgam um ranking e prestigio às escolas para aumentar suas matrículas; e medem de maneira indireta o desempenho dos professores, que de ser positiva se traduziria na concessão de estímulos econômicos.

A avaliação dos professores, presta-se a uma política de estímulos diferenciados que leva a competência entre eles. Desde os anos 1989, por recomendações do FMI e do Banco Mundial, começou a "Carrera do Magistério", que consiste num sistema de pagamentos segundo os méritos no desempenho dos professores (ABOITES, Hugo, 2013; COLL, 2013). Os princípios de qualidade total, segundo o qual precisam-se mecanismos de premiação ao trabalho para aumentar a produtividade, trasladaram-se à escola.

$\mathrm{Na}$ LGE, os professores são considerados os principais protagonistas do sistema educacional, o que significa que o Estado deixa a responsabilidade dos resultados educacionais nos professores, ao tempo que estabelece fortes mecanismos de controle para assegurar a qualidade na educação. A avaliação representa o principal mecanismo de "controle e intervenção Estatal na educação" (COLL, 2013, p.47).

Segundo Paro (2003, p. 33-34), a avaliação é um atividade natural que o homem faz constantemente ao longo de sua atividade para garantir que os objetivos propostos estão sendo atingidos, e no caso que seja necessário, tomar decisões a tempo e reorientar o processo. A este tipo de avaliação Freitas (2007) denomina de "avaliação formativa".

Porém, o sentido que a avaliação toma nos processos pedagógicos ${ }^{113}$, é no sentido de avaliar os resultados, só no final do processo e "[...] corre-se o risco de, em não se alcançando os resultados desejados, perdem-se os recursos e desperdiçar-se o tempo despendido no decurso da ação." (PARO, 2003, p. 35). Freitas (2007), denomina avaliação somativa, a este tipo de práticas.

Um processo pedagógico é um processo de trabalho em que o objetivo é a apropriação cultural do homem, sendo o objetivo da educação, o homem. (PARO, 2003).

113 “A educação se dá por meio da ação pedagógica [...]" (PARO, 2003, p. 35). 
A educação, possibilita a apropriação dos conhecimentos produzidos social e historicamente, é um processo continuo e "ativo" que se estabelece entre o sujeito e a sociedade, na atividade social do homem (LEONTIEV, 1978). Desta forma, como assinala Moraes (2008, p. 24), a avaliação "[...] deve levar em consideração os elementos sócio-históricos de construção do homem."

No capitalismo, toma-se ao homem como um objeto, como um fator mais da produção, que tem a propriedade de criar valor, sua avaliação no processo de produção estará focada a sua produtividade que gere um maior lucro para a empresa.

As relações de produção determinam, assim, o objetivo da avaliação e suas formas (NAGEL apud MORAES, 2008). No neoliberalismo, os objetivos econômicos definem os objetivos educacionais, e o homem deixa de ser objeto educacional, 0 capital humano toma esse lugar. Nesta educação neoliberal, será necessário avaliar, para classificar aos homens segundo suas capacidades em produzir, em ser produtivos. Este tipo de avaliações, funcionam como instrumentos de controle, de subordinação e de exclusão escolar. E a responsabilidade dessa exclusão é transladada ao sujeito, seja o estudante ou o professor.

Para uma avaliação formativa escolar, é necessário ter em conta, o objetivo, isto é "[...] o ideal de homem que se deseja formar, qual o papel da escola na formação dos indivíduos. Desse modo, as práticas avaliativas da aprendizagem escolar não podem ser compreendidas por si mesmas, mas estão inseridas num contexto maior." (MORAES, 2008, p. 26). Os processos de ensino-aprendizagem, a qualidade e a avaliação da educação são processos complexos que não podem ser reduzidos a simples princípios econômicos.

Segundo Aboites Hugo (2013), por qualidade da educação, desde a ótica neoliberal, devem-se entender também, os conteúdos, conhecimentos, habilidades e competências que devem desenvolver os estudantes, segundo as necessidades laborais, conceitos todos que "[...] relacionam-se com tornar o 'individuo capaz de determinados desempenhos'." (GAGNÉ apud MORETTI, 2007, p. 62). Os currículos nacionais, estão sendo adaptados conforme os requerimentos do capital privado. As áreas humanitárias, as artes, a filosofia, não são de interesse do sistema produtivo, e desta forma, elas estão sendo relegadas dos programas de estudo, empobrecendo assim, a formação dos alunos.

Para o Banco Mundial e a UNESCO (FRIGOTTO; CIAVATTA, 2003), a educação é vista como o "[...] instrumento fundamental para desenvolver nos 
indivíduos a capacidade de responder a esses desafios [da globalização, e da sociedade do conhecimento] particularmente a educação média." (Ibid., p. 99).

A qualidade educacional neoliberal, visa na formação fragmentada e focada no desenvolvimento de "indivíduos" desintegrados, flexíveis e competentes que saibam "[resolver] problemas ou alcançar resultados" (RAMOS, 2016), num mundo altamente competitivo e globalizado. As oportunidades laborais apresentam-se como um esforço e um "atributo" individual (RAMOS, 2016). Só os homens autônomos, competentes e produtivos são aptos para ter sucesso no mercado laboral e na vida. Justificam-se assim as diferenças sociais, "medindo a inteligência".

O Serviço Profissional Docente, convertido em Lei em 2013, tem o objetivo de regular o ingresso, promoção e permanência laboral dos professores da educação básica. A formação desse capital humano, que é o professor (desde a visão neoliberal) precisa contar com padrões de qualidade, de alto desempenho curricular, com isto assegura-se a alta produtividade e sua excelência no processo educacional. As diversas avaliações, cursos de formação inicial e permanente, e os esquemas de estímulos econômicos a que estão sujeitos, subordinam aos professores a uma dinâmica repressiva e competitiva. Perde-se o objetivo da educação, fragmenta-se o trabalho do professor quem perde a totalidade do processo de ensino, uma vez que se converte em técnico, executor de tarefas e de conteúdos vazios, sem sentido para ele nem para o educando. Tanto o professor como o aluno estão agora preocupados pela permanência no sistema escolar, em ensinar e aprender aquilo que é importante para o sistema e que se verá refletido nos exames únicos, homogêneos e de opção múltipla. Se define a hierarquia do professor em função de seu desempenho e de sua participação para com esse sistema. Em poucas palavras, aliena-se mais o trabalho docente.

Com as avaliações e o Serviço Profissional Docente, se legaliza a exploração, a intensificação laboral e o despido injustificado de professores "críticos" que não são úteis ao sistema. Suprime-se o espírito livre de estudantes e professores, reduz-se o trabalho pedagógico a um trabalho individualista e a-histórico, técnico e sem sentido.

Só a educação possibilita a constituição do homem histórico, e o trabalho como mediação é quem possibilita tal processo. O trabalho forma ao sujeito, é na sua "atividade prático-sensorial", na sua "prática social", que se desenvolvem as faculdades psicológicas superiores, entre elas a consciência e o pensamento. 
A reforma educativa 2013, está legalizando práticas capitalistas em todo o processo educativo, tem mudado o sentido social educativo, denigra ao estudante e ao professor ao considerá-lo capital humano, o trabalho educativo neoliberal visa a constituição de homens alienados que possam ser subordinados e explorados pelo sistema econômico em geral.

De que tipo de aprendizagem e de qualidade educativa estamos então falando? Que tipo de homens e de sociedade queremos? Quais as possibilidades? 


\section{O ESTADO NEOLIBERAL FRENTE À RESISTÊNCIA DA SOCIEDADE CIVIL PARA EXISTÊNCIA DA ESCOLA PÚBLICA}

Diante a imposição de uma política educativa alienante, classista, e focada na formação de capital humano, se abrem possibilidades para uma mudança, esperemos não distante.

A aprovação da reforma educativa 2013, contrária às necessidades educacionais, gerou uma amplia mobilização dos professores do ensino básico principalmente, e de grande parte da população. Surgiu uma análise e reflexão, sobre o papel do Estado na educação, das necessidades educacionais, do papel do professor na educação nacional, assim como propostas de professores e acadêmicos de universidades públicas diante o rápido processo privatizador da educação.

Os professores pertencentes à CNTE encabeçam este importante processo que é de interesse nacional. Como vimos, a educação como formador da consciência e personalidade do homem pode transformar a realidade social. Resulta indispensável que os mexicanos participemos na defesa de uma educação pública, gratuita e formadora de homens integrais.

Neste capítulo, falaremos brevemente da relação dos movimentos sociais com o desenvolvimento econômico do país, o como a presença dos representantes do capital financeiro e econômico nacional e internacional, se encontram presentes ao longo da história mexicana para impelir que se formulem políticas sociais que favoreçam o empoderamento da sociedade. Os movimentos sociais, têm criado experiência e consciência social. Desde o ponto de vista do capital, faz-se necessário sufocar estes movimentos, corrompê-los e apagar na memória do povo as lutas e todos os direitos obtidos nelas.

O movimento do magistério representa uma esperança para que o povo mexicano não perda o mais valioso, a educação.

\subsection{Breve resenha dos movimentos sociais e da educação no México}

No México houve um grande auge económico, social e político no sexênio de Lázaro Cárdenas del Río (1934-1940). Impulsou-se uma reforma agrária que permitiu 
a formação de "ejidos" mas sobretudo a organização dos "ejidos coletivos"114", uma instituição que tem como propósito o desenvolvimento rural e a incorporação do camponês à vida política do país; para tal fim, repartiram-se 17,890,000 hectares nesse período e criaram-se grandes sistemas de irrigação. A criação do Banco Nacional de Crédito Ejidal permitiu canalizar recursos para a consecução desses objetivos, á vez que possibilitou a presença do Estado no planejamento e organização nas "sociedades de crédito ejidal". (CANABAL, 1988; GILLY, 1994).

O grande impulso à educação neste período, representa o caminho para atingir a reforma agrária, além de favorecer a justiça e a igualdade de oportunidades para a população. A educação desde a perspectiva histórico-cultural permite socializar a cultura - que é tudo aquilo produzido historicamente pela sociedade -, vista assim, a educação atuaria como mediação para integrar aos camponeses à sociedade, ao restituir-lhes a condição de sujeitos, com a possibilidade de contribuir conscientemente e com conhecimento no seu desenvolvimento e no projeto econômico do país.

A continuação, reproduzo em palavras de Canabal (1988), o papel que the é atribuído à educação no período de Cárdenas:

A educação foi impulsionada com a finalidade de reforçar a repartição agrária, tanto num sentido político, para que o [camponês] ejidatario pudesse conhecer os seus direitos e defendê-los, como, em apoio à organização das novas unidades produtivas, assim, a educação apoiava e reforçava o processo de desenvolvimento rural. Os professores, eram ao mesmo tempo educadores e "catalisadores de movimentos populares", e no campo da "luta pela terra" eram eficazes atores de mudança social no campo, porta-vozes e líderes de camponeses, que assumiam com eles o enfrentamento dos poderes locais e sofriam como eles as represálias dos grandes latifundiários. (CANABAL, 1988, p. 132, tradução nossa).

Porém, o objetivo de educação neste período não se restringe somente ao campo, porque como foi mencionado no subitem 4.2, em 1934 foi reformada a

\footnotetext{
114 O "ejido" é uma figura agraria que surge durante a Revolução mexicana e ela é chave para a consecução da Reforma Agrária plasmada na Constituição de 1917. Seu objetivo é eliminar o latifúndio para restituir e distribuir a terra ás comunidades de camponeses, e também dar fim à exploração que existe no campo. Durante o período presidencial de Cárdenas, conforma-se em especial o "ejido coletivo" que funciona como uma cooperativa, em que a comunidade toda, trabalha e administra conjuntamente a terra, a maquinaria, a agua e os créditos. (CANABAL, 1988).
} 
Constituição, estabelecendo uma educação socialista para o ensino fundamental (obrigatório) e o ensino médio. O presidente Cárdenas congruente como esse objetivo cria muitas escolas em zonas rurais, escolas regionais camponesas (para formar professores para as zonas rurais); funda também o Instituto Politécnico Nacional (IPN), o Conselho Técnico de Educação Agrícola, a Escola Nacional de Educação Física a Escola Nacional de Antropologia e História, o Instituto Nacional de Antropologia e História, o Arquivo Histórico da Fazenda, o Departamento de Assuntos Indígenas, o Conselho de Línguas Indígenas, o Instituto de Física e Matemáticas e a Faculdade de Ciências da Universidade Autónoma de México, e a Casa de Espanha no México, agora conhecido como o "Colegio de México", (GILLY, 1994; QUINTANILLA, 2016). Todas estas escolas e institutos contribuíram de maneira decisiva à cultura ciência, e investigação no México.

A Casa de Espanha no México, brindou abrigo aos intelectuais espanhóis republicanos, e esta é ainda um local importante de desenvolvimento científico. Diante a invasão falangista e o assassinato de milhares de livres pensadores, socialistas e comunistas, o presidente Cárdenas colaborou com a república espanhola, e o México recebeu a quinhentos meninos e a mais de quarenta mil republicanos exilados (GILLY, 1994; QUINTANILLA, 2016).

A política educativa com Cárdenas, foi pensada para erradicar a pobreza, o latifúndio, o analfabetismo, as doenças, a religião, e para formar profissionais que pudessem contribuir no desenvolvimento econômico e social do país.

Foi respeitada a existência dos sindicatos operários, assim como sua democracia interna. A infraestrutura-estradas do país cresceu em grande medida. $O$ 23 de junho de 1937 Cárdenas decreta a expropriação dos bens do transporte ferroviário Ferrocarriles Mexicanos (cria-se Ferrocarriles Nacionales de México) e o 18 de março de 1938 a indústria petrolífera. (GILLY, 1994).

O apogeu do país, assim como a visão democrática e social de Cárdenas, declinou no sexênio seguinte, no mandato de Manuel Ávila Camacho (1940-1946). Iniciaram-se pouco a pouco mudanças substanciais, recomendadas pelo governo dos Estado Unidos de América, para "eliminar as modificações comunistas" introduzidas nesse período. Imediatamente se dificultou o crescimento dos "ejidos coletivos", começou-se a cercear o crescimento educacional com o fechamento paulatino das escolas do IPN, começando com a Escola Superior de Medicina Rural e a Escola Superior de Engenheira e Arquitetura; fecharam-se também casas de estudantes, 
entre outras instituições educacionais. Todo isto provocou o surgimento de grandes movimentos sociais. (SANDOVAL, 2008).

Em março, setembro de 1942, realizaram-se greves e manifestações no Distrito Federal (DF), - a capital do México - para evitar o desmembramento do IPN e dos internados estudantis. (lbid.).

Nesse mesmo ano, os estudantes e professores da Escola Normal Rural de Ayotzinapa ${ }^{115}$, organizaram uma greve para exigir à SEP a entregue dos recursos econômicos. Nesta escola, o diretor imposto pelo governo federal, cúmplice dos grandes fazendeiros locais, demitiu aos professores com mais consciência social. O conflito durou vários meses, e finalmente, os alunos que tinham sido presos foram libertados porque não existiam provas em contra deles. Posteriormente, o diretor de Ayotzinapa e o Secretário de Educação tiveram que demitir (GARCÍA, 2011).

$O$ setor educacional não tem sido o único em sofrer ataques governamentais posteriores ao sexênio de Cárdenas (1934-1940). Podemos mencionar a greve dos operários e camponeses do engenho açucareiro de Zacatepec (Morelos), em 1942, que defenderam terras e ao mesmo engenho ante a tentativa de saqueio. Estão também, as modificações à Constituição em 1951 para favorecer às empresas mineiras, fato que desencadeou greves no país todo, destacando-se a "Caravana da fome" dos mineiros de Nueva Rosita (Coahuila) (BASURTO, 1984); a gigantesca greve do magistério em 1958 por melhores condições salariais, de trabalho e democracia sindical (LOYO, 1979); a greve do setor ferroviário de 1958 em que centenas de trabalhadores foram encarcerados e milhares demitidos (ALONSO, 1972); a greve de médicos e enfermeiros em 1964 (POZAS, 1993); os movimentos guerrilheiros dirigidos pelos professores Genaro Vázquez Rojas y Lucio Cabañas Barrientos (que iniciaram-se como movimentos populares em defesa dos educandos), movimentos que tem gerado grande consciência social, porém sem êxito nas demandas, porque a prioridade dos governos têm sido responder às pressões da banca e do capital internacional (MONTEMAYOR, 1990), assim como aos organismos internacionais (como foi referido ao longo do trabalho), antes que às necessidades da população e dos trabalhadores.

A expansão do capital, tem sido a causa para a ingerência das empresas e instituições internacionais na vida econômica e política no México (assim como no

115 Que se localiza em Ayotzinapa, uma pequena localidade do Estado de Guerrero, no México. 
resto dos chamados "países em desenvolvimento"). A terra com seus recursos naturais, o trabalho dos trabalhadores mexicanos, e a educação (formação de estudantes que solucionem as necessidades do mercado) estão sendo entregues ao capital interacional, modificando a Constituição para legalizar as práticas comerciais nas instituições sociais, e poder tirar todo direito social e histórico à população. Tratase de eliminar qualquer barreira para a mundialização do capital e do lucro.

No México, existe uma longa história de lutas sociais, em que o movimento do magistério, se tem unido para apoiar a outros movimentos populares, sobretudo aos camponeses e indígenas.

A continuação, apresentaremos a experiência mais atual do movimento do magistério diante o movimento acelerado privatizador da educação, presente na reforma educativa 2013. A luta dos professores da educação básica, abre uma esperança para uma educação pública e gratuita no México.

\subsection{A reforma educativa 2013 no México e a resistência política dos professores da educação básica e da sociedade civil.}

No México como em muitos países da América Latina, a problemática social, converte aos professores em lideres comprometidos com suas comunidades e por tanto, são um obstáculo para os empresários. Como temos falado, as organizações internacionais como a Organização para a Cooperação e Desenvolvimento Econômico (OCDE), o Banco Mundial, e o Fundo Monetário Internacional tem imposto medidas de privatização da educação e mecanismos legais para controlar aos sindicatos. $O$ Sindicato Nacional dos Trabalhadores da Educação (SNTE) foi fortemente golpeado em 1958 e o governo conseguiu comprar aos dirigentes afins ao regímen. Depois de um descenso na atividade gremial e ante uma grande corrupção no SNTE, em 1979 foi criada a Coordenadora Nacional de Trabalhadores da Educação (CNTE) que tem desenvolvido inumeráveis lutas em defesa da educação pública ao longo de seus 37 anos, junto com outros setores sociais. (ARRIAGA, 2013)

Atualmente o SNTE é o sindicato mais grande do México, com mais de 1.5 milhões de afiliados, completamente corporativo (a exceção de quem milita na CNTE), ao serviço do governo. A CNTE desde seus inicios tem denunciado a corrupção do SNTE com práticas recorrentes, tais como, a venda de praças, (COLL, 2016) pressão dos professores para que votem pelo PRI, usurpação do dinheiro das contribuições 
sindicais, intimidação aos professores, etc. As denúncias não têm prosperado ante a justiça, já que o governo protege aos secretários do SNTE, incondicionais ao poder.

Ainda que, desde o sexênio do presidente Carlos Salinas de Gortari (19881994) tinha-se incluído no discurso aumentar a qualidade da educação básica, tão só um pequeno grupo de integrantes da CNTE descobriu as implicações e a magnitude das transformações que estavam à frente.

Quando se estabeleceu-se o Acordo Nacional para a Modernização da Educação Básica (ANMEB) em 1992-93 e foi aprovada a Lei Geral da Educação que forneceu respaldo legal, o magistério não tinha a experiência nem o nível de consciência que adquiriu em 2012. Um grande aprendizado foi obtido como resultado das lutas especialmente de maio a dezembro de 2006 em Oaxaca com a participação ativa dos professores da CNTE seção 22, que aproveitando a conjuntura eleitoral, obtiveram um movimento popular unificado, formando a Assembleia Popular dos Povos de Oaxaca (APPO), integrada por diversas organizações em defesa dos direitos humanos e cidadãos, (MARTíNEZ, 2006). Outro referente é 2008, especialmente quando se manifestaram contra a Aliança pela Qualidade da Educação, no sexênio de Felipe Calderón (2006-2012) e no 2011, quando se opuseram à Avaliação Universal (ABOITES, 2015).

A experiência desses vinte anos (1992-2012) tinha formado não somente a nova gerações de líderes e lutadores sociais experientes na discussão e na resistência, mas também, tinha dado passo a avanços qualitativos muito importantes na percepção no movimento mesmo no interior da CNTE.

Em 2008, fica claro que na luta e as demandas já não eram para exigir "democracia e mais salario" como tinha sido a consigna inicial, quando se formou a CNTE, senão também, por um projeto educativo nacional (ABOITES, 2015; COORDENADORA NACIONAL DE TRABALHADORES DA EDUCAÇÃO, 2013).

A apresentação oficial da reforma educativa 2013, centrou-se no discurso de liberar a educação do controle do SNTE liderado por Elba Esther Gordillo - secretaria geral do SNTE desde 1989 -, de "recuperar a reitoria do estado" sobre a educação e "por ordem nos professores". Ainda que o tom era forte, agressivo e desqualificativo em alguns jornais afins à postura oficial, os professores assumiram que se tratava de uma pugna entre o SNTE e o governo federal, razão pela qual, não ocasionou uma reação da oposição generalizada no grêmio magistral. Posteriormente, ficou claro que 
tratava-se de um plano muito bem orquestrado, de preparar a população em geral, para desqualificar qualquer protesto dos professores. ABOITES, 2015).

No pacote de mudanças constitucionais que propus o governo, que incluía a reforma energética, fiscal, laboral, de telecomunicações, a reforma educativa foi uma linha mais com a qual abriu-se o processo, acompanhada como já foi mencionado, de uma campanha de desqualificações contra os professores". Como mencionamos no subitem 3.3, foi evidente a prematura governamental para aprovar a reforma educativa sem maior reflexão. A iniciativa apresentou-se no 10 de dezembro de 2012 e para o 21 do mesmo mês já tinha sido aprovada pelas duas câmaras. Como assinalamos, a reforma centra-se principalmente: na avaliação educacional, no serviço professional docente e na autonomia das escolas. (ABOITES, 2015).

Com estes antecedentes encontramo-nos em 2013, frente a um movimento do magistério histórico pela força que adquiriu com a participação massiva de professores, incluso pela incorporação de professores em outras sessões que não pertenciam a CNTE. Estas mobilizações têm prosseguido durante os seguintes três anos ao longo do território nacional, com diversas ações e incorporando cada vez mais simpatizantes e força popular.

Ao longo do ano 2013 o México foi cenário da participação de mais de 600 mil professores "[...] nas greves parciais ou indefinidas de até 3 meses [...]" (ARRIAGA, 2013, p. 2), de inumeráveis manifestações, plantões e gigantescas assembleias, foros regionais, jornadas de leitura e classes em praças públicas, em diferentes entidades do pais, plantões no Zócalo ${ }^{116} \mathrm{com}$ milhares de professores na Cidade do México e de outras capitais do pais, fechamento de estradas, fechamento das fronteiras ao norte e sul do pais; fechamento de acessos ocasionais ao aeroporto, à residência oficial dos Pinos, na Bolsa de valores, ao redor da SEP, à Suprema Corte de Justicia117, Palácio Nacional118, monopólios da televisão, centros comerciais; protestas frente às sedes dos principais partidos políticos, (PRI, PAN, PRD), assim como, o cercamento dos Congresso nacional e local. Foi principalmente na capital da república onde concentrou-se a maior expressão da protesta e mais duradoira. Paralelamente foram feitas visitas a embaixadas, organizaram-se conferencias

\footnotetext{
116 É a praça principal da cidade do México (capital do México), situada no seu centro histórico. Seu nome é Plaza de la Constitución, mas se conhece como El Zócalo.

117 Supremo Tribunal Federal.

118 Sede do Poder Executivo Federal e do gabinete presidencial, como o Palácio do Planalto no Brasil.
} 
nacionais e internacionais, adquirindo um caráter no só nacional, mas também internacional. (ABOITES, 2015; ARRIAGA, 2013).

As intensas e continuas mobilizações do sector do magistério de 2013 surgiram com o objetivo de reverter a modificação ao artículo $3^{\circ}$ da Constituição, que como foi indicado, permitiu a imposição de novas regulações e alienação dos docentes. Com esta disposição, elimina-se a permanência nas suas praças, assim como, a contratação coletiva. É evidente, que a Reforma Educativa 2013 é uma reforma administrativa neoliberal para controlar ainda mais aos professores e a o maior sindicato do México ao (SNTE).

A Reforma Educativa afeta não somente aos professores na escola básica, mas também aos do ensino médio, escolas técnicas e escolas normais; pelo qual o movimento CNTE tem sido apoiado em toda a Republica. Populações inteiras têm manifestado o apoio à CNTE. Por exemplo em Nochixtlán ${ }^{119}$ (Oaxaca) a população inteira apoiou no 2016 o fechamento da estrada que conduz a Cidade de Oaxaca; de modo que o governo federal encaminhou ao exército e a polícia federal, quem conjuntamente com a estatal, assassinou aos cidadãos indefensos que estavam à frente na barricada e produz dezenas de mortos e feridos. Em Chilpancingo ${ }^{120}$ (Guerrero), em fevereiro de 2013, foi bloqueada a estrada México-Acapulco, pela Coordenadora de Trabalhadores da Educação de Guerrero ${ }^{121}$ (CETEG), ação que foi igualmente reprimida violentamente pelas policias federal e estatal. (ABOITES, 2015).

Paralelamente às ações armadas contra o movimento do magistério, os médios de comunicação a nível nacional, porta-vozes à política oficial, "[...] encarregaram-se de projetar [a imagem] de professores violentos, [...] preocupados pelo seu posto de trabalho, que não queriam ser avaliados." (ARRIAGA, 2013, p. 3, tradução nossa). Estas notícias continuas, tem pretendido mau informar a população e tem formado um cenário legal para deter aos principais dirigentes magistrais, quem estão nas prisões por meses, sem ser julgados, o bem, declarados culpáveis com penas exageradamente grande por delitos criados, não reais.

O governo nunca imaginou a força que cobraria o movimento do magistério, que iniciou o dia 25 de fevereiro de 2013 (dia em que se promulga a reforma educativa com o Presidente da República, os integrantes do Pacto por México e o Secretário de

\footnotetext{
119 Asunción Nochixtlán, é uma cidade localizada na região Mixteca, no estado de Oaxaca, 120 Chilpancingo de los Bravo, é a capital do Estado de Guerrero.

${ }^{121}$ Coordinadora de Trabajadores de la Educación de Guerrero.
} 
Educação Pública, Emilio Chuayffet), no Estado de Guerrero com a CETEG, e que seguiria em 26 estados mais da República mexicana. Diante estes grandes movimentos sociais, em maio de 2013, o governo decide realizar fóruns de discussão em vários estados, para fazer crer aos professores e à população a disposição para um diálogo sobre a reforma educativa. (ARRIAGA, 2015; ABOITES, 2015).

Estes fóruns permitiram a reunião de aproximadamente dez mil professores das áreas rurais, das comunidades afastadas, das diversas cidades da República; de pesquisadores de várias universidades públicas, e da sociedade em geral, que enriqueceram os debates e as análises sobre as condições atuais da educação no México, e as consequências das chamadas "reformas educativas", que iniciaram-se em 1992. Elaboraram-se centenas de documentos, com reflexões e propostas, que sintetizam toda a experiência destes professores da educação básica. (ARRIAGA, 2015; ABOITES, 2015). Aboites (2015, p. 86) sublinha como estes fóruns “[...] reforçaram os argumentos e ampliaram consideravelmente a visão dos dirigentes do magistério, dos próprios professores e dos pais de família. Isto permitiu incluir perspectivas e demandas que não tinham sido mencionadas anteriormente." Com estes centros de debate e discussão, o movimento do magistério cresceu.

Porém o dia 11 de setembro de 2013, sem tomar em conta as propostas nem os argumentos contra a reforma educativa, o governo aprova as Leis regulamentadoras da reforma educativa. A implementação destas Leis, são apresentadas à sociedade como parte desses fóruns e, portanto, legitimadas pelos professores.

Todos estes fatos mostram o autoritarismo, criminalidade e ilegalidade do atual governo. A coragem e consciência de todos os professores, dos estudantes normalistas (é preciso se lembrar dos 43 estudantes desparecidos), que lutaram e estão lutando por uma educação pública e gratuita, por condições laborais e salariais justas, são um exemplo de dignidade e de esperança para todos os mexicanos. É preciso nos solidarizar com eles. 


\section{CONSIDERAÇÕES FINAIS}

A chamada "reforma educativa 2013" de caráter presidencial, tem um caráter administrativo laboral. Entre seus objetivos: privatizar a educação (com todas as formas possíveis que isto significa), exercer um maior controle sobre o magistério mediante simples "avaliações" de opção múltipla, avaliações tanto para professores como para os alunos, como instrumento para definir a suposta "qualidade educativa". Avaliações que definem agora 0 ingresso, a promoção e a permanência dos professores; diferenciam e classificam aos estudantes.

A responsabilidade da educação nacional é entregue aos professores, enquanto a responsabilidade do aprendizado aos alunos.

A comparação entre os estudantes, mensurados por seu desempenho escolar, intensifica ainda mais a desigualdade social, posto que ao desconsiderar como variável relevante as diferenças sociais, contribui para ocultá-las, suprimindo-as do debate educacional.

Com essas reflexões sistematizamos em cinco itens as conclusões do trabalho:

a) acelerada dinâmica de mercantilização das economias em relação direta com a Mercantilização da educação. Como fenômeno internacional, a educação é alocada no setor serviços como um novo e amplo mercado para a mundialização do capital, prevalecendo para amplos setores das sociedades a lógica do mercado na educação.

b) através de organismos internacionais, sob discursos declarados de neutralidade e preocupação social, verifica-se a regulação constitucional de projetos hegemônicos.

c) disseminam-se princípios políticos e econômicos neoliberais que incidem sobre práticas educativas-administrativas na escola pública mexicana tais como competitividade e avaliações de larga escala.

d) controle do magistério mediante as avaliações nacionais, que associam os resultados com os incentivos salariais.

e) privatização da educação no México com a aprovação desta última reforma educativa. 
Não se poderia deixar de fazer referência ao fato de que a abertura tem transformado os mercados laborais, sobretudo por meio da flexibilização do trabalho.

Finalmente destaca-se que mudanças na educação no México, e sobretudo com a reforma 2013 estão focadas totalmente em questões administrativas e laborais e não pedagógicas. A educação se tem aberto ao investimento privado e forma parte dos grandes acordos internacionais de livre comércio. O sistema educativo forma parte da política conjunta de reformas econômicas e políticas, entre elas a laboral que redefine uma nova divisão do trabalho pedagógico, parcelariza e aliena o trabalho docente, legaliza a exploração e intensificação laboral, por meio da subcontratação (outsourcing), do pagamento por horas e tempo de trabalho, e da demissão injustificada.

Tais conclusões, indicam a gravidade do quadro político educacional vivido em México e a necessidade de aprofundamento de estudos sobre as reformas educativas em toda a América Latina, posto que se trata de projeto global necessário à atual fase de reestruturação do capital. 


\section{REFERÊNCIAS}

ABOITES AGUILAR, Hugo. Tratado de Libre Comercio y educación superior: el caso de México, un antecedente para América Latina. Perfiles educativos, v. XXIX, n. 118, 2007, p. 25-53.

. La medida de una nación: los primeros años de la evaluación en México. Historia de poder y resistencia (1982-2010). 1‥ ed. México, DF: UAM-X, CSH, Depto. de Educación y Comunicación, 2012., p. 985.

La medida de una nación. Documento apresentado no 1eiro Foro Regional, Análise e Perspectivas sobre a Reforma Educacional, realizado em 31 de maio de 2013, em Morelia, Michoacán, México. Disponível em: $<\mathrm{https}: / /$ xa.yimg.com/kq/groups/.../name/Hugo+Aboites+Morelia+Mich+31+may.pdf>. Acesso em: 4 maio 2016.

. Implicaciones de la reforma de 2012 al artículo $3^{\circ}$ Constitucional. El Cotidiano, México, n. 179, p. 27-42, maio-jun. 2013.

ABOITES AGUILAR, Jaime. La innovación tecnológica en países industrializados y en desarrollo. Revista Ciecas Innovación y Consultoría, México: IPN, v. I, dez. 1998.

ALCÁNTARA SANTUARIO, Armando. Algunos saldos de la política educativa en la primera década del siglo XXI. Campus Milenio, México, n. 400, 27 jan. 2011. Disponível em:

$<w w w . s e s . u n a m . m x /$ publicaciones/artículos. php?proceso=vicusaliza\&idart=959>. Acesso em: 4 maio 2016.

ALTMAN, Helena. Influências do Banco Mundial no projeto educacional brasileiro. Educação e Pesquisa, São Paulo, v.28, n.1, p. 77-89, jan/jun. 2002.

ANDERSON, Perry. Balanço do neoliberalismo. In: SADER, Emir; GENTILI, Pablo, (Org.). Pós-Neoliberalismo: as políticas sociais e o Estado democrático. São Paulo: Paz e Terra, 1995, p. 9-23.

ANTUNES, Ricardo. Adeus ao trabalho?: ensaio sobre as metamorfoses e a centralidade no mundo do trabalho. São Paulo: Cortez, 2014.

APPLE, Michael W. Educando à direita: mercados, padrões, deus e desigualdade. São Paulo: Cortez: Instituto Paulo Freire, 2003.

ARCHIBUGI, Daniele; MICHIE, Jonathan. Technology and innovation: an introduction. UK, Cambridge Journal of Economics, n. 19, p. 1-4.

Technical change, growth and trade: new departures in institutional economics. UK, Journal of Economic Surveys, n. 12 (3), p. 113-332.

ARNAUT, Alberto. La federalización educativa en México: historia del debate sobre la centralización y la descentralización educativa (1889-1994). México: El Colégio de México, Centro de Estudios Sociológicos, 1998.

BALL, Stephen J. Diretrizes políticas globais e relações políticas locais em educação. Currículo sem Fronteiras, v.1, n. 2, pp. 99-116, jul./dez. 2001. 
BALL, Stephen J.; Youdell, Deborah. Hidden privatization in public education. Education International, $5^{\text {th }}$ World Congress, Jul. 2007. Disponível em:<http://download.eiie.org/IRISDocuments/Research\%20Website\%20Documents/ 2009-00034-01-E.pdf >. Acesso em: 19 fev. 2015.

BARBA, Bonifacio. La nueva ley general de educación. Sinéctica, México, n. 4, jan./jun. 1994. Disponível em:

$<$ https://www.sinectica.iteso.mx/index.php/SINECTICA/article/view/541/534>.

Acesso em: 4 maio 2016.

BARUCH VERDUZCO, Zazil-Há. Evaluación del programa de escuelas de calidad en el nivel de educación primaria en el Estado de Puebla: El caso de Asesores Técnico-Pedagógicos, Supervisores y Jefes de Sector, un estudio cualitativo. 2007. Capítulo 3, p. 52-95. Dissertação (Mestrado em Qualidade da Educação) Universidad de las América Puebla, Escuela de Ciencias Sociales, Artes y Humanidades, Departamento de Ciencias de la Educación, Cholula, Puebla. Disponível em:

<catarina.udlap.mx/u_dj_a/tales/documentos/mce/Baruch_v_z/capitulo3.pdf>. Acesso em: 4 maio 2016.

CANABAL CRISTIANI, Beatriz. El cardenismo y el nuevo rostro de la sociedad rural. Revista Mexicana de Sociología, México, Universidad Nacional Autónoma de México, vol. 50, n. 3, jul./set., p. 125-156, 1988.

CAPDEVIELLE, Mario. Composición tecnológica de la industria manufacturera mexicana. Revista El mercado de valores, México, Nacional Financiera, p. 18-27, 2000.

CHAUÍ, Marilena. A universidade pública sob nova perspectiva. Revista Brasileira de Educação, n. 24, set./out./nov./dez., p. 5-15, 2003.

CHESNAIS, François. Doce tesis acerca de la mundialización del capital. Argentina: Instituto Argentino para el Desarrollo Económico. Disponível em: $<$ https://imas2010.files.wordpress.com/2010/06/chesnaisdocetesis11.pdf $>$. Acesso em: 1 jun. 2015.

COLL LEBEDEFF, Tatiana. La reforma educativa, el poder del Estado y la evaluación. El Cotidiano, México, n. 179, maio/jun., p. 43-53, 2013.

COORDINADORA NACIONAL DE TRABAJADORES DE LA EDUCACIÓN. Análisis y perspectivas de la reforma educativa: Memorias y resolutivos, julio 2013. México: CNTE, jul. 2013.

CORDERO, Graciela; LUNA, Edna; PATIÑO, Norma Xóchitl. La evaluación docente en educación básica en México: panorama y agenda pendiente. Sinéctica, México, n. 41, jul./dez. 2013. Disponível em:

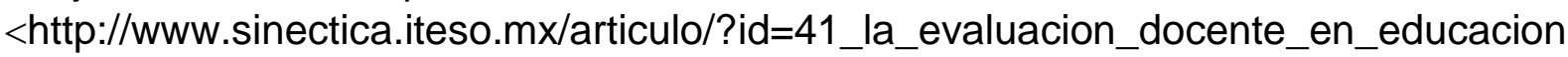
_basica_en_mexico_panorama_y_agenda_pendiente>. Acesso em: 9 out. 2015. 
DABAT, Alejandro. Globalización, capitalismo actual y nueva configuración espacial del mundo. In: BASAVE, Jorge. Globalización y alternativas incluyentes para el siglo XXI. México: Miguel A Porrúa-UNAM-UAM-A, 2002, p. 41-88.

DISCURSO íntegro del Presidente Peña Nieto a la nación. Excélsior, sección nacional. México, 1 dez. 2012.

DOSI, Giovanni. Una reconsideración de las condiciones y los modelos del desarrollo: una perspectiva "evolucionista" de la innovación, el comercio y el crecimiento. Revista Pensamiento Iberoamericano, México, n. 20, p. 167-191, 1991.

DOSI, Giovanni; PAVITT, Keith; SOETE, Luc. The economics of Technical change and International Trade. Great Britain: Harvester Wheatsheaf, 1990.

DUNNING, John. The consequences of international transfer technology by MNEs: some home country implicationes. In: SANJAYA, Lall. The economic of technology transfer. UK: Edward Elgar, 2001. p. 172-204.

ENCABEZA Fox la firma del "Compromiso Social por la Calidad de la Educación". Proceso, sección Estados. México, 9 ago. 2002.

ESTAY, Jaime. La globalización económica y sus significados. 1993. p.37-51.

FERREIRA JR., Amarilio; BITTAR, Marisa. A educação na perspectiva marxista: uma abordagem baseada em Marx e Gramsci. Interface-Comunicação, Saúde, Educação, v.12, n.26, p. 635-646, jul./set. 2008.

FLORES SALGADO, José. Cambio estructural e integración regional de la economía mexicana: un estudio de desintegración industrial. México: Universidad Autónoma Metropolitana, Unidad Xochimilco, División de Ciencias Sociales y Humanidades; Juan Pablos Editor, 2010.

FRIGOTTO, Gaudêncio. Educação e a crise do capitalismo real. São Paulo: Cortez, 2000.

FRIGOTTO, Gaudêncio; CIAVATTA, Maria. Educação básica no Brasil na década de 1990: subordinação ativa e consentida à lógica do mercado. Educação e Sociedade, Campinas, v. 24, n. 82, p. 93-130, abr. 2003.

GADOTTI, Moacir. Concepção dialética da educação: Um estudo introdutório. São Paulo: Cortez, 1988.

GARCIA LORCA, Federico. Discurso íntegro pronunciado por Federico García Lorca en la inauguración de la biblioteca de su pueblo natal, Fuente Vaqueros (Granada), en septiembre del año 1931. Disponível em: $<$ https://algundiaenalgunaparte.com/2016/06/09/medio-pan-y-un-libro-de-federicogarcia-lorca/>. Acesso em: 30 set. 2016.

GARCíA SOLÍS, Iván. Larga historia de agresiones a normales rurales. La Jornada, México, 18 dez. 2011. Seção Opinión, p. 31. 
GARCIA, Teise; ADRIÃO, Theresa; BORGHI, Raquel. A Nova Gestão Pública no contexto brasileiro. In.: MARTINS, A. (Org.). Instituições Educacionais: políticas, gestão e práticas profissionais. Santos: Editora Universitária Leopoldianum, 2009, p. 13-263.

GILLY, Adolfo. El cardenismo: uma utopia mexicana. México: Cal y Arena, 1994.

GOMES, Nilma Lino. As práticas pedagógicas com as relações étnico-raciais nas escolas públicas: desafios e perspectivas. In: GOMES, Nilma L. (Org.). Práticas pedagógicas de trabalho com relações étnico-raciais na escola na perspectiva da Lei n 10.639/03. Brasília: Ministério da Educação/UNESCO, p.19-33, 2012.

GONZÁLES BOLAÑOS, Ondina. Los contextos de la investigación, la educación superior y el nuevo valor del conocimiento en América Latina. Revista de Indias, España, v. LX, n. 219, p. 565- 581, mayo-agosto, 2000.

GONZÁLEZ PÉREZ, Luis R.; FONSECA CORONA, Francisco J. El marco legislativo de la educación. México: UNAM. Disponível em:

$<$ www.planeducativonacional.unam.mx/pdf/CAP_16.pdf >. Acesso em: 11 jul. 2016.

GRAMSCI, Antonio. La política y el Estado moderno. Barcelona: Biblioteca Pensamiento Crítico (Público). 2009.

HERNÁNDEZ, Gregorio. Reformas educativas recientes y nueva Ley de educación: la modernización educativa en México. Educación de adultos, México, Instituto Nacional para la Educación de los Adultos, Secretaría de Educación Pública, Disponível em:

<bibliotecadigital.conevyt.org.mx/servicios/hemeroteca/070/070008.pdf>. Acesso em: 17 jun. 2015.

HILL, Dave. O neoliberalismo global, a resistência e a deformação da educação. Currículo sem Fronteiras, v. 3, n. 2, pp. 24-59, p. 24-59, jul./dez. 2003.

IBARRA, David. Ensayos sobre economia mexicana. México: Fondo de Cultura Económica, 2006.

KOPNIN, Pável Vasilievich. A dialética como lógica e teoria do conhecimento. Rio de Janeiro: Civilização Brasileira, p. 45-90, 1978.

KRAWCZYK, Nora. Políticas de regulação e mercantilização da educação: socialização para uma nova cidadania?. Educação e Sociedade, Campinas, v. 26, n. 92, p. 799-819, Out. 2005.

KRAWCZYK, Nora Rut; VIEIRA, Vera Lucia. México: A ilusão igualitária e a modernização da educação. In: KRAWCZYK, Nora Rut; VIEIRA, Vera Lucia. A reforma educacional na América Latina nos anos 1990. São Paulo: Xamã, 2008, p. 101-128. 
LEONTIEV, Alexis. O homem e a cultura. In: $O$ desenvolvimento do psiquismo. Lisboa: Livros Horizonte, v. 14, 1978, p. 261-284.

. Actividad, conciencia y personalidad. México: Editorial Cartago. 1984.

LOYO BRAMBILA, Aurora. El sello de la alternancia en la política educativa: México 2000-2005. Revista Mexicana de Investigación Educativa, México, v.11, n. 30, p. 1065-1092, jul./set. 2006. Disponível em:<www.redalyc.org/pdf/140/14003016.pdf>. Acesso em: 20 set. 2016.

MARX, Karl. Prefácio. In: Contribuição à crítica da economia política. São Paulo: Martins Fontes, p. 23-27, 1977.

El capital. México: Siglo veintiuno editores, I.1, v.2, 1975a.

El capital. México: Siglo veintiuno editores, l.1, v.3, 1975b.

El capital. México: Siglo veintiuno editores, I.1, v.1, 1988.

Manuscritos econômico-filosóficos. São Paulo: Boitempo, 2008.

MEDINA, Sara Rosa (Coord.). Políticas y educación: la construcción de un destino. México: CONACYT/UNAM-Posgrado en Pedagogía/Ediciones Díaz de Santos, 2011.

MÉSZÁROS, István. A teoría da alienação em Marx. São Paulo: Boitempo, 2006.

. La educación más allá del capital. Argentina: Siglo XXI Editores Argentina; CLACSO, 2008.

MINAYO, María Cecília de Souza. O desafio do conhecimento: Pesquisa qualitativa em saúde. São Paulo: Hucitec, 2008.

MONTEMAYOR, Carlos. La guerra en el paraíso. México: Editorial Diana, 1990.

Los pueblos indios de México: evolución histórica de su concepto y realidad social. México: Debolsillo, 2010.

MORAES, Silvia Pereira Gonzaga de. Avaliação do processo de ensino e aprendizagem em matemática: contribuições da teoria histórico-cultural. 2008. 260f. Tese (Doutorado) - Universidade de São Paulo, Faculdade de Educação, São Paulo.

MORETTI, Vanessa Dias. Professores de matemática em atividade de ensino: uma perspectiva histórico-cultural para a formação docente. 2007. 208f. Tese (Doutorado) - Universidade de São Paulo, Faculdade de Educação, São Paulo.

MOZAMMEL, Huq M. Transfer of advanced technologies to developing countries: problems and prospects. Science, Technology and Development, London, n. 16 (3), pp.111-118, 1998.

NEVES, Lúcia Maria Wanderley; SANT'ANNA, Ronaldo. Introdução: Gramsci, o Estado educador e a nova pedagogia da hegemonia. In: NEVES, Lúcia Maria Wanderley (Org.). A nova pedagogia da hegemonia: estratégias do capital para educar o consenso. São Paulo: Xamã, p. 19-39, 2005.

OLIVEIRA, Betty. A dialética do singular-particular-universal. Disponível em: <stoa.usp.br/gepespp/files/3115/17336/ADialéticaDoSingularParticularUniversal.pdf> . Acesso em: 14 out. 2014. 
ORNELAS, Carlos. Centralismo burocrático en la educación de México. In: DA CUNHA, Célio et al. (Org.). Políticas públicas de educação na América Latina: lições aprendidas e desafios. Campinas, SP: Autores Associados, 2011. p. 93-112.

ORTEGA Y GASSET, José. Meditação da técnica. Rio de Janeiro: Livro IberoAmericano, 1963.

PARO, Vitor Henrique. Escritos sobre educação. São Paulo: Xamã, 2001. Reprovação escolar: renúncia à educação. São Paulo: Xamã, 2003. Educação como exercício do poder: crítica ao senso comum em educação. São Paulo: Cortez, 2010. Crítica da estrutura da escola. São Paulo: Cortez, 2011. Administração escolar: introdução crítica. São Paulo: Cortez, 2014. A teoria do valor em Marx e a educação. São Paulo: Cortez, 2013.

PAVITT, Keith. Technology transfer among the industrially advanced countries: an overview. In: SANJAYA, Lall. The economic of technology transfer. UK: Edward Elgar, 2001, p. 455-475.

PERONI, Vera Maria Vidal; OLIVEIRA, Regina Tereza Cestari de; FERNANDES, Maria Dilnéia Espíndola. Estado e terceiro setor: as novas regulações entre o público e o privado na gestão da educação básica brasileira. Educação e Sociedade, Campinas, v.30, n. 108, p. 761-778, out. 2009.

PEIXOTO, Adão José. Divisão do trabalho pedagógico e alienação. Nuances, v. I, n. 1, p. 41-47, set. 1995.

PINO, Angel Sirgado. As origens da constituição cultural da criança na perspectiva de Lev S. Vigotski. In: As marcas do humano. São Paulo: Cortez, 2005. Capítulo I, p. 43-68.

QUINTANILLA, Susana. La educación en México durante el periodo de Lázaro Cárdenas, 1934-1940. Disponível em:

<http://biblioweb.tic.unam.mx/diccionario/htm/articulos/sec_31.htm>. Acesso em: 27 out. 2016.

RADOSEVIC, S. International technology transfer and catch-up in economic development. UK: Edward Elgar, 1999.

RAMOS, Marise Nogueira. A pedagogia das competências e a psicologização das questões sociais. Disponível em: <>. Acesso em: 8 set. 2016.

ROBERTSON, Susan; VERGER, Antoni. A origem das parcerias público-privada na governança global da educação. Educação e Sociedade, Campinas, v. 33, n. 121, p. 1133-1156, out./dez. 2012.

RODRIGUES, Priscilla de Paula. Instituto Unibanco e o projeto jovem de futuro: uma forma de inserção dos empresários nas políticas públicas educacionais para o 
ensino médio. 2016. 142 f. Dissertação (Mestrado em Educação) - Universidade de São Paulo, Programa de Pós-Graduação em Educação, Ribeirão Preto.

ROSARIO, Martha Verónica del. El «bono escolar»: financiación por la demanda, desfinanciación de la educación pública. Revista Atlántida, n.2, p. 235-253, dez. 2010.

RUBINSTEIN, S.L. Problemas das faculdades e questões da teoria psicológica. In: RUBINSTEIN, S.L. Problemas da psicologia geral. Moscou, 1973, p. 236-242.

RUSSO, Miguel Henrique. Escola e paradigmas de gestão. Eccos Revista Científica. Universidade Nove de Julho, Brasil, v. 6, n. 1, p. 25-42, jun. 2004.

SÁNCHEZ DAZA, Germán. Retos tecnológicos frente a la globalización. México, 2000. Disponível em: <http://www.redem.buap.mx>. Acesso em: 30 jul. 2000.

Reforma educativa: el camino de la mercantilización. Texto presentado en el Foro de "Análisis e implicaciones de la reforma educativa", organizado por el Consejo Magisterial Poblano Centro, la Coordinadora nacional de Trabajadores de la Educación, el frente por la Reivindicación Universitaria Fracción Roja, 25 de jun. de 2013.

SANDOVAL CRUZ, Pablo. Su lucha social en Guerrero por un mundo mejor. México: Plaza y Valdés Editores, 2008.

SAVIANI, Dermeval. Educação brasileira: estrutura e sistema. Campinas, SP: Autores Associados, 2000.

Educação socialista, pedagogía histórico-crítica e os desafios da sociedade de classes. In: LOMBARDI, José Claudinei e SAVIANI, Dermeval (Orgs.). Marxismo e educação: debates contemporâneos. Brasil: Autores Associados, 2008. p. 223-274.

SAXE-FERNÁNDEZ, John. Globalización: crítica a un paradigma. Problemas del Desarrollo, México: IIEC-UNAM, v. 28, n. 110, jul./set., 1997.

SMITH, Adam. De la división del trabajo. In: SMITH, Adam. Investigación sobre la naturaleza y causas de la riqueza de las naciones. México: Fondo de Cultura Económica, 1999. Cap. I, p. 7-15.

Del principio que motiva la división del trabajo. In: SMITH, Adam. Investigación sobre la naturaleza y causas de la riqueza de las naciones. México: Fondo de Cultura Económica, 1999, Cap. II, p. 15-18.

SOLOW, R. El cambio técnico y la función de producción agregada. In: ROSENBERG, Nathan. Economía del cambio tecnológico. México: El trimestre Económico, Fondo de Cultura Económica, Lecturas 31, 1990.

TOUSSAIN, Eric. Ideología y política neoliberales: perspectiva histórica. In: TOUSSAIN, Eric. La bolsa o la vida: las finanzas contra los pueblos. Argentina; CLACSO, 2004, cap. 13, p. 179-189. 
TREVIÑO RONZÓN, Ernesto; CRUZ VADILLO, Rodolfo. La reforma integral de la educación básica en el discurso docente. Perfiles educativos, México, v. XXXVI, n. 144, p.50-68, 2014.

VIANA, Giomar; FERRERA DE LIMA, Jandir. Capital humano e crescimento econômico. Interações, Campo Grande, v. 11, n. 2, p. 137-148, jul./dez 2010.

VIGOTSKI, Lev Semenovitch. Estructura de las funciones psíquicas superiores. In: Obras escogidas. Vol. III (Problemas del desarrollo de la psique). Madrid: Visor, cap. 4. p. 121-138, 1995a.

. Génesis de las funciones psíquicas superiores. In: Obras Escogidas. Vol. III (Problemas del desarrollo de la psique). Madrid: Visor, cap. 5, p. 139-168, 1995b.

. Manuscrito de 1929. Revista Educação \& Sociedade, Campinas, ano XXI, n. 71, p. 21-44, Jul. 2000.

A transformação socialista do homem. Disponível em:

<http://www.pstu.org.br>. Acesso em: 24 jun. 2015.

XAVIER, Antonio Carlos. Gestão da qualidade total nas escolas: um novo modelo gerencial para a educação. Instituto de Pesquisa Econômica Aplicada, Brasília, texto para discussão n. 234, 1991.

\section{DOCUMENTOS}

COMISIÓN NACIONAL PARA EL DESARROLLO DE LOS PUEBLOS INDÍGENAS. Regiones indígenas de México. México 2006. Disponível em:

$<$ http://www.gob.mx/cms/uploads/attachment/file/35735/cdi-regiones-indigenasmexico.pdf $>$. Acesso em: 7 fev. 2017.

INSTITUTO NACIONAL DE ESTADÍSTICA Y GEOGRAFÍA. Número de habitantes. México, 2017a. Disponível em:

$<$ http://cuentame.inegi.org.mx/poblacion/habitantes.aspx?tema=P>. Acesso em: 7 fev. 2017.

Analfabetismo. México, 2017b. Disponível em:

<http://cuentame.inegi.org.mx/poblacion/analfabeta.aspx?tema=P >. Acesso em: 7 fev. 2017.

INSTITUTO NACIONAL PARA LA EVALUACIÓN DE LA EDUCACIÓN. Panorama educativo de México: indicadores del sistema educativo nacional 2010, educación básica y media superior. México, 2012. Disponível em: $<w w w . i n e e . e d u . m x>$. Acesso em: 3 ago. 2016.

Panorama educativo de México: indicadores del sistema educativo nacional 2014, educación básica y media superior. México 2015a. Disponível em: <www.inee.edu.mx>. Acesso em: 3 ago. 2016.

ORGANIZAÇÃO DAS NAÇÕES UNIDAS PARA A EDUCAÇÃO, A CIÊNCIA E A CULTURA. Escuelas multigrados: ¿cómo funcionan? Reflexión a partir de la 
experiência evaluativa del proyecto Escuelas Multigrado Innovadas. República Dominicana 2003. Disponível em:

<unesdoc.unesco.org/images/0013/001374/137497so.pdfs. Acesso em: 15 nov. 2016.

ORGANIZAÇÃO PARA A COOPERAÇÃO E DESENVOLVIMENTO ECONÔMICO. Acuerdo de cooperación México-OCDE para mejorar la calidad de la educación de las escuelas mexicanas. Mejorar las escuelas: estrategias para la acción en México. Resúmenes ejecutivos. OCDE, 2010. Disponível em:

$<w w w . o e c d . o r g / e d u / s c h o o l / 46216786$.pdf $>$. Acesso em: 4 maio 2016.

. Descentralización educativa en México: un recuento analítico. OCDE, 2009. Disponível em:<www.oecd.org/mexico/44906363.pdf>. Acesso em: 7 jul. 2014.

Avances en las reformas de la educación básica en México: una perspectiva de la OCDE. OCDE, 2012. Disponível em:<>. Acesso em:.

Revisiones de la OCDE sobre la evaluación en educación: México 2012. OCDE; SEP; INEE, 2014. Disponível em:

$<$ publicaciones.inee.edu.mx/buscadorPub/P1/C/231/P1C231.pdf $>$. Acesso em: 4 maio 2016.

Pacto por México. México, 2012. Disponível em:

$<$ www.foroconsultivo.org.mx/documentos/politicas_publicas/pacto_por_mexico.pdf>. Acesso em: 4 ago. 2016.

REFORMA Educativa 2012-2013: cronología de la reforma. México. Disponível em: <pac.ife.org.mx/debate_democratico/descargas/Reforma-Educativa-2012-2013.pdf>. Acesso em: 4 ago. $201 \overline{6}$.

SECRETARIA DE EDUCACIÓN PÚBLICA. La estructura del sistema educativo mexicano. Out. 2000. Disponível em:

<www.sep.gob.mx/work/models/sep1/Resource/1447/1/images/sistemaedumex09_0 1.pdf>. Acesso em: 11 jul. 2016.

Coordinación General de Educación Intercultural y Bilingüe. Disponível em: <eib.sep.gob.mx/diversidad>. Acesso em: 11 jul. 2016a.

Instituto Nacional para la Educación de los Adultos. Disponível em: <www.inea.gob.mx>. Acesso em: 3 ago. 2016b.

Subsecretaria de Educación Superior: Instituciones de educación superior. Disponível em: <www.ses.sep.gob.mx/instituciones.html>. Acesso em: 3 ago. 2016c.

. Telesecundaria. Disponível em:

$<w w w . t e l e s e c u n d a r i a . s e p . g o b . m x / m o d e l o \_e d u c a t i v o . p h p>$. Acesso em: 3 ago. 2016d.

\section{LEGISLAÇÃO}

MÉXICO. Acuerdo Nacional para la Modernización de la Educación Básica. Diario Oficial de la Federación, México, 19 maio 1992. Disponível em:< https://www.sep.gob.mx/work/models/sep1/Resource/b490561c-5c33-4254-ad1caad33765928a/07104.pdf >. Acesso em: 2015. 
Secretaria de Educación Pública. Programa Nacional de Educación 2001-2006. Por una educación de buena calidad para todos: un enfoque educativo para el siglo XXI. México, setembro de 2001. Disponível em:<file///C:/Users/User/Downloads/Plan_educ_2001_2006.pdf >. Acesso em: 4 maio 2016.

Secretaria de Educación Pública. Programa Escuelas de Tiempo Completo. Gobierno Federal. México, 2009. Disponível em:

$<$ www.iea.gob.mx/webiea/tiempo_completo/archivos/MATERIAL\%20DE\%20APOYO/ CAJA\%20DE\%HERRAMIENTAS/ORIENTACIONES\%20PEDAGOGICAS\%20GENE RAL.pdf >. Acesso em: 4 maio 2016.

Secretaria de Educación Pública. Alianza por la calidad de la educación. Gobierno Federal; SEP; SHCP; SEDESOL; SALUD. Disponível em:<file:///C:/Users/User/Dowloads/alianza_educacion_mexico.pdf $>$. Acesso em: 4 maio 2016.

. Iniciativa de Decreto que reforma y adiciona diversas disposiciones de la Constitución Política de los Estados Unidos Mexicanos. Presidencia da República. México, 10 de dez. 2012. Disponível em: <pactopormexico,org/ReformaEducativa.pdf>. Acesso em: 10 nov. 2014.

Inciativa constitucional que reforma, adiciona e revoga diversas disposições da Lei Geral de Educação, de Lei do Instituto Nacional para a Avaliação da Educação e de Lei Geral do Serviço Profissional Docente. Gaceta Parlamentaria. México, 16 ago. 2013a, Número 3837-I. Disponível em:

< gaceta.diputados.gob.mx/Gaceta/62/2013/ago/20130816.html>. Acesso em: 10 nov. 2014.

. Ley General del Servicio Profesional Docente. Diario Oficial de la Federación, México, 11 set. 2013b. Disponível em:

$<$ http://www.diputados.gob.mx/LeyesBiblio/pdf/LGSPD.pdf>. Acesso em: 10 nov. 2014.

. Ley del Instituto Nacional para la Evaluación de la Educación. Diario Oficial de la Federación, México: 11 set. 2013c. Disponível em: <https://www.sep.gob.mx/work/models/sep1/Resource/558c2c24-0b12-4676-ad908ab78086b184/ley_instituto_nacional_evaluacion_educativa.pdf $>$. Acesso em: 10 nov. 2014.

. Constituição (2016) Constitución Política de los Estados Unidos

Mexicanos. México: Cámara de Diputados del H. Congreso de la Unión, 29 jan. 2016a. Disponível em: < http://www.ordenjuridico.gob.mx/Constitucion/cn16.pdf>. Acesso em: 30 jul. 2016.

. Ley General de Educación. Diario Oficial de la Federación, México, 1 jun. 2016b. Disponível em:

< https://www.sep.gob.mx/work/models/sep1/Resource/558c2c24-0b12-4676-ad908ab78086b184/ley_general_educacion.pdf>. Acesso em: 30 jul. 2016.

. Plan Nacional de Desarrollo 2013-2018. Gobierno de la República de los Estados Unidos Mexicanos. México, Disponível em: $<$ https://transparencia.info.jalisco.gob.mx/sites/default/files/PLAN_NACIONAL_DE_D ESARROLLO_2013-2018_0.pdf>. Acesso em: 30 jul. 2016. 